\title{
BREAKING THE GLASS CEILING? THE EFFECT OF BOARD QUOTAS ON FEMALE LABOR MARKET OUTCOMES IN NORWAY
}

\author{
Marianne Bertrand \\ Sandra E. Black \\ Sissel Jensen \\ Adriana Lleras-Muney \\ Working Paper 20256 \\ http://www.nber.org/papers/w20256 \\ NATIONAL BUREAU OF ECONOMIC RESEARCH \\ 1050 Massachusetts Avenue \\ Cambridge, MA 02138 \\ June 2014, Revised July 2017
}

The views expressed herein are those of the authors and do not necessarily reflect the views of the National Bureau of Economic Research.

NBER working papers are circulated for discussion and comment purposes. They have not been peer-reviewed or been subject to the review by the NBER Board of Directors that accompanies official NBER publications.

(C) 2014 by Marianne Bertrand, Sandra E. Black, Sissel Jensen, and Adriana Lleras-Muney. All rights reserved. Short sections of text, not to exceed two paragraphs, may be quoted without explicit permission provided that full credit, including $\odot$ notice, is given to the source. 
Breaking the Glass Ceiling? The Effect of Board Quotas on Female Labor Market Outcomes

in Norway

Marianne Bertrand, Sandra E. Black, Sissel Jensen, and Adriana Lleras-Muney

NBER Working Paper No. 20256

June 2014, Revised July 2017

JEL No. J24,J3,J7,J78

\section{ABSTRACT}

In late 2003, Norway passed a law mandating 40 percent representation of each gender on the board of public limited liability companies. The primary objective of this reform was to increase the representation of women in top positions in the corporate sector and decrease the gender disparity in earnings within that sector. We document that the women appointed to these boards post-reform were observably more qualified than their female predecessors along many dimensions, and that the gender gap in earnings within boards fell substantially. On the other hand, we see no robust evidence that the reform benefited the larger set of women employed in the companies subject to the quota. Moreover, the reform had no clear impact on highly qualified women whose qualifications mirror those of board members but who were not appointed to boards. Finally, we find mixed support for the view that the reform affected the decisions of young women: while the reform was not accompanied by any change in female enrollment in business education programs, we do see some improvements in labor market outcomes for young women with graduate business degrees in their early career stages; however, we observe similar improvements for young women with graduate science degrees, suggesting this may not be due to the reform. Overall, seven years after the board quota policy fully came into effect, we conclude that it had very little discernible impact on women in business beyond its direct effect on the women who made it into boardrooms.

Marianne Bertrand

Booth School of Business

University of Chicago

5807 South Woodlawn Avenue

Chicago, IL 60637

and NBER

marianne.bertrand@chicagobooth.edu

Sandra E. Black

Department of Economics

University of Texas at Austin

Austin, TX 78712

and IZA

and also NBER

sblack@austin.utexas.edu

\author{
Sissel Jensen \\ Norwegian School of Economics \\ Helleveien 30 \\ NO-5045 Bergen \\ Norway \\ sissel.jensen@nhh.no \\ Adriana Lleras-Muney \\ Department of Economics \\ 9373 Bunche Hall \\ UCLA \\ Los Angeles, CA 90095 \\ and NBER \\ alleras@ECON.UCLA.EDU
}




\section{Introduction}

Despite significant labor market progress over the last decades, women remain heavily underrepresented in high-earnings, high-status occupations. This is particularly true in the financial and corporate sectors of the economy. In a 2017 census of Fortune 500 companies in the U.S., Catalyst found that women held only $19.9 \%$ of corporate board seats and comprised only $5.8 \%$ of CEO positions in those companies. In Europe, on average only $23.3 \%$ of board members of the largest publicly listed companies are women and 5.1\% of the CEOs (EU 2016), despite being 45\% of the labor force, and these numbers are even smaller in other parts of the world (Pande and Ford, 2011).

This phenomenon - that women are under-represented at the top of the labor market and wage gender gaps are larger there than average - is often referred to as the glass ceiling. It is pervasive, observed even in countries that are otherwise thought of as having achieved the most progress in terms of gender equality. Norway is one of these countries. While the gender gap in wages in Norway was less than $14 \%$ on average among full time workers in 2002 , it was $20 \%$ among college graduates. ${ }^{1}$ In 2000 , only $5 \%$ of board members in public limited liability companies were women, and their annual earnings were more than 30 percent lower than those of their male counterparts on the same boards.

To address this disparity, in December 2003 Norway passed a law requiring 40\% representation of each gender on the board of directors of public limited liability companies, also referred to as ASA companies. Because most firms did not voluntarily comply, in January 2006 the law became compulsory, and firms that did not comply by January 2008 were to be dissolved. The median percentage of female board members among public limited companies reached $40 \%$ by 2008 , from a median of $0 \%$ in 2003 (see Appendix Table A1).

The idea of mandating gender quotas on corporate boards has been gaining further political traction in Europe in recent years. Following Norway's lead, Belgium, France, Germany, Iceland, India, Israel, Italy, and Spain have all passed similar reforms. In 2014, the new German coalition government passed legislation requiring that corporate boards be comprised of at least 30\% women by 2016 (or else the seat would be left vacant). On November 20, 2013, the European parliament voted in favor of a proposed draft law that would require 40\% female board members in about 5,000 listed companies in the European Union by 2020; state-owned companies would be required to comply by 2018 .

While prior work has examined the secondary impact of the Norwegian reform on the stock market valuation, accounting performance, and corporate policies of targeted companies (see among others Johansen and Sandnes 2008, Nygaard 2011, Ahern and Dittmar 2012, Matsa and Miller 2013, Nygaard 2011, and Eckbo, Nygaard, and Thorburn 2016), in this paper we investigate whether the quota

\footnotetext{
${ }^{1}$ Background figures in the Norwegian Technical Calculation Committee for Wage Settlement committee's report submitted to the Ministry of Labor and Social Inclusion before the income settlement in 2012, Norwegian Ministry of Labor and Social Affairs (2012), tables 1.17 and 1.18 (NOU 2012: 11).
} 
policy has been successful in its primary objective of reducing gender disparities in the corporate sector, up to 7 years after the policy became compulsory.

In theory, quotas can be an effective tool to improve gender equality. This is particularly true if path dependence is a key factor for the under-representation of women in the highest corporate echelons. Because qualified women might be harmed by an absence of networks to help them climb the corporate ladder, quotas can provide the initial step up that women need to break this cycle. If discrimination is the key factor for the under-representation of women, quotas might help overcome business prejudice (and improve efficiency) by forcing more exposure to talented women in positions of power (Beaman et al 2009, Rao 2013). However, if high-quality women cannot be found, the quotas may backfire and reinforce negative stereotypes, resulting in a "patronizing equilibrium" with women investing less in their careers as they see that it does not require much to become a board member (Coate and Loury 1993).

We start by investigating the effect of the Norwegian reform on the qualifications of board members. Opponents of the reform claimed there were not enough qualified women in Norway to fill the reserved board seats. Businesses were particularly vocal in expressing this concern in their lobbying against the reform (Criscione 2002). ${ }^{2}$ Moreover, businesses may have decided to "game" the reform by strategically appointing sub-par women to their boards, expecting such women would be only minimal participants in board decisions. If unqualified women are appointed, then the possible benefits of the reform to others might also be muted, as these women may not serve as inspiring role models, have strong business networks, or be vocal proponents of pro-female changes within the targeted companies.

We show that these concerns were not realized in practice. The average observable qualifications of the women appointed to the boards of public limited liability companies significantly improved after the reform. While there is a substantial gap in observable qualifications between male and female board members both before and after the reform, this gap is smaller after the reform. In addition, the gender gap in earnings within boards fell after the reform.

We then explore how the reform impacted the labor market outcomes of women working in the companies that were mandated to increase female representation on their board. Does an increase in female share in the boardroom translate into the recruitment or promotion of more women within these firms? If boards play a role in the selection of upper-level management, female board members might be vocal proponents of female candidates for these positions, or might be able to leverage their own femaleheavier business networks to recommend female candidates for these positions. In addition, if boards can help shape human resource policies, female board members might be more likely to support changes in

${ }^{2}$ See also Storvik and Teigen (2010) and Heidenreich (2010). 
corporate policies that improve work-family balance, such as more part-time work or more amenities for women with children.

Following Ahern and Dittmar (2012), we exploit variation across public limited liability companies in the pre-reform (2003) fraction of women on their board to identify the effect of the reform. Companies that started with a larger share of women on their board had to make fewer changes to comply with the mandate, while companies that started with a smaller share had to make more changes. We find no robust evidence to support the view that the mandated greater share of women on the board improved outcomes for women employed in ASA companies. The addition of women to the boardroom did not systematically increase the representation of women in the top echelons of these companies (defined as top quartile, decile and vigintile of the companies' income distribution, or the C-Suite). We also find no robust evidence consistent with the view that the work environment at these companies became more family-friendly.

We then look at the impact of the mandate on a broader set of highly qualified women in the Norwegian labor market--women whose qualifications mirror those of board members but were not (yet) appointed to a board. There are several theoretical reasons as to why the mandate may indirectly improve labor market outcomes for these women. First, if board membership is an attractive prize, these women have additional motivation to remain on the business "fast-track" after the reform, as the odds of "winning this prize" went up. Second, since the search for female board members helped in bringing these qualified women to the attention of businesses (e.g. many of these women may have been featured in the database compiled by the government to make companies aware of qualified female candidates), this may have reduced search frictions in the filling of other executive positions by women throughout the economy.

We identify these effects by comparing the gender gap in labor outcomes across 4 cohorts of men and women with similarly high business qualifications, with 2 cohorts predating the reform, one cohort when the reform was taking place, and one cohort post-dating the reform. We find no evidence of statistically significant differential improvements for women in the post-reform cohort, neither in terms of average earnings nor likelihood of filling in a top position in any Norwegian business.

Finally, we consider whether the reform affected younger women who might be considering a business education, specifically those who are enrolled in a business education program, or have recently graduated from such a program. While these young women are unlikely to be directly impacted by the reform (they are too young to be considered for a board position or a top executive position), it is possible that the reform inspired them to consider a business career, or that they saw greater benefits of investing more in the early stages of their career. We find mixed evidence but also a hint of a more positive message, even though our inference is weakest in this part of the analysis. There was no differential increase in female enrollment in business programs after the reform. Results of a qualitative survey that 
we conducted in the Fall of 2013 at the Norwegian School of Economics, the top business school in Norway, suggest that female (and male) students are well aware of the reform and that many of them expect women to professionally benefit from it in terms of future earnings and likelihood of holding a top executive position. Yet very few female students report that the reform got them to reconsider their fertility plans (such as delaying fertility), which prior research suggests might be one of the biggest hurdles in keeping women with a business degree on the fast track (Bertrand, Goldin and Katz, 2011). Comparing 4 cohorts of recent graduates from business programs ( 2 pre-reform, one during the reform, and one post-reform), we do see relative improvements in early career labor market outcomes for young women with graduate business degrees in the post-reform cohort; however, we also observe similar patterns for young women with graduate degrees in science fields, suggesting this may not be a result of the reform.

\section{Context}

\section{A. The Corporate Board Gender Quota Reform}

Gender quotas legislating minimum representation of women on boards of directors were first introduced in Norway in 1981 and, at that time, only applied to government appointed boards, councils, and committees. This remained the status quo for almost twenty years. In 2001, the Norwegian government began official discussions to implement a more expansive board quota policy. Teigen (2012) suggests that the privatization of state-owned firms in the 1980s and 1990s had led to concerns about fairness because these newly privatized firms would no longer be covered under the existing legislation. The first change in the law was proposed in 2002, and in December 2003, the Norwegian Company Act was revised. The previous quota for publicly appointed boards, council, and committees would now also apply to public limited liability companies (known as ASA firms in Norway). This new law stated that all public limited liability companies were required to have at least $40 \%$ representation of each gender on their boards. ${ }^{3}$ By 2005 however, the fraction of women on boards of directors of ASA firms was still only 17\% (see Appendix Table A1), so sanctions were introduced. Affected firms had until January 1, 2008 to comply or would be subject to forced dissolution. By 2009, the median share of women on the boards of ASA firms was $40 \%$, with the distribution heavily skewed to the right compared to the pre-reform period (see Figure 1).

\footnotetext{
${ }^{3}$ The mandated gender representation depends on the total number of directors on the board. If the board of directors has two or three members, both genders must be represented. If the board has four or five members, there must be at least two members of each gender, and if the board has six to eight, each must have at least three. If the board has nine members, there should be at least four members of each gender. Beyond that, there must be at least $40 \%$ of each gender. Median board size in ASA firms has been 5 throughout the 2000s (see Appendix Table A1). In Norwegian firms above a certain size (200 employees), employees have the right to elect one third of the board members and the rule above was to apply separately to employee-elected board members and shareholder-elected board members. Hence, in particular in the case of smaller boards and firms with employeeelected board members, compliance can be achieved with less than $40 \%$ female representation.
} 
Business was overall opposed to the law, arguing that there was a lack of qualified women to fill the reserved board positions. ${ }^{4}$ To address this concern, the government created a database of women interested in being appointed to boards "to make women's competence more visible" (Ahern and Dittmar, 2012; Storvik and Teigen, 2010). When faced with the quota, firms could either choose to comply with the law or change their legal form. Appendix Table A1 shows that a large number of the companies that were ASA in 2003 were no longer ASA companies after 2003. While not all of these exits out of the ASA form were due to changes in legal form (some companies disappeared due to bankruptcies or mergers and acquisitions), a non-trivial share was. For example, out of the 380 of the 581 companies that were ASA in 2003 and were still in existence in 2008, only 186 retained their ASA legal form in that year.

Several papers have investigated the question of whether quota avoidance drove the switches out of ASA status. Ahern and Dittmar (2002) focused on the subsample of publicly traded ASA companies (e.g those traded on the Oslo Stock Exchange) and showed that the likelihood of de-listing anytime between 2003 and 2009 was greater among those firms that had a smaller share of women on their board pre-reform. In their sample of 119 listed ASA firms in 2002, Ahern and Dittmar (2012) found that 46.3\% of those that had no female directors in 2002 had delisted by 2009 , compared to only $30.8 \%$ of those with at least one female director in 2002. More recently, Bohren and Staubo (2014) and Eckbo, Nygaard and Thorburn (2016) have re-examined the question of whether the quota policy induced exit out of the ASA form by extending the sample under study to all ASA firms, e.g. both those that are publicly traded (as in Ahern and Dittmar (2002)) as well as those that are not. Relying on press releases, both studies start by excluding from their analysis firms that exited the ASA form for reasons they argue to be unlikely related to the quota policy. ${ }^{5}$ The two studies come to contradictory conclusions. Bohren and Staubo (2014) confirm Ahren and Dittmar's findings by showing that exit out of the ASA form between 2000 and 2009 was more common among firms with fewer female directors. ${ }^{6}$ In contrast, Eckbo, Nygaard and Thorburn (2016) fail to find a statistically relationship between the likelihood of conversion from public to private limited liability company and a greater shortfall in female representation on the board. ${ }^{7}$

\footnotetext{
${ }^{4}$ Board members' responsibilities at ASA companies are regulated by the Public Limited Liability Companies Act of 1997 and match common board member responsibilities in other corporate laws. In particular, directors serve both a management and a supervisory function. While the CEO is responsible for the daily management of the company, he or she is subject to instructions and guidelines of the board of directors regarding the company's business. Such instructions and guidelines require the support of a majority of the directors to become resolutions. In their supervisory function, the directors must keep themselves informed about the company's financial position and ensure that its activities, accounts and asset management are subject to adequate control. The directors are also generally responsible for appointing (and firing) the CEO of the company. Moreover, the directors have a fiduciary duty to perform their responsibilities in the best interests of the company.

${ }^{5}$ Both studies also exclude financial firms because financial firms were requited to adopt the ASA form until a 2007 law lifted this requirement.

${ }^{6}$ Bohren and Staubo (2014) also show that exit out of ASA was more common among smaller firms, younger firms, non-listed firms and firms that are not family-controlled.

${ }^{7}$ The differences in findings appear related to differences in the construction of the final sample (e.g. which are the "unrelated" exits that are excluded from the analysis) as well as differences in econometric specifications.
} 
In Appendix Table A2, we provide another data point on this question. In particular, we focus on the set of 380 firms that were ASA in 2003 and were still in existence in 2008. We then correlate the likelihood of having exited the ASA form by 2008 with gender representation on the board in 2003. We find that firms that had a lower percentage of women on their board in 2003, or no female representation on their board at all in 2003, were more likely to have exited the ASA form by 2008. This pattern is much more pronounced among firms that had larger boards in 2003. So, while there is some remaining controversy regarding this question, we take seriously in this paper the possibility that some public limited liability companies may have changed their legal form in order to avoid the quota policy. We directly address the potential for selection in and out of ASA status after the quota policy was announced by tracking the effect of the reform on both ASA firms and on firms that were ASA in 2003 (an "intent-totreat" sample).

\section{B. Related Literature}

Existing evidence on the effects of the Norwegian board quota has focused on the relationship between board composition and firm performance. To date, the evidence on the stock market response to the quota remains inconclusive. Johansen and Sandnes (2008) argue that stock prices of affected firms declined with the 2002 announcement, and Ahern and Dittmar (2012) document that firm value (as proxied by Tobin's Q) declined with the 2002 announcement. However, Nygaard (2011) finds that stock prices actually increased with the 2005 announcement while recent work by Eckbo, Nygaard, and Thorburn (2016) suggests that the change was value-neutral.

Ahern and Dittmar (2012) also examine the effect of the quota on corporate policies and accounting performance. Using data from firms' annual reports, they show that the average age and experience of the new female directors was significantly lower than that of the existing male directors and argue that this change led to a (statistically insignificant) decline in accounting returns of the firm. In addition, affected firms grew in size and made more acquisitions as a result of the change. In a similar vein, using publicly available data, Matsa and Miller (2013) examine the effect of the quota on accounting performance. Using firms in Sweden as a control group, they show that the change in the board quota law led to a decline in operating profits, primarily due to fewer layoffs. Other recent work has examined the effect of gender board quotas in other countries. ${ }^{8}$ None of these papers look at how the quota affected the outcomes of women at the top of the labor market.

\footnotetext{
${ }^{8}$ Hinnerich and Jansson (2017) show that the threat of a gender board quota in Sweden increased the share of female board members in potentially affected firms, and this increase was accompanied by an improvement in firm performance. Ferrari et al (2016) examine the effect of the gender quota in Italy and find that the quota led to an increased share of female board directors and overall higher levels of education of board members with no overall impact on firm performance and a positive effect on stock market value. Comi et al (2016) examine the effects of board quotas in Belgium, France, Italy, and Spain and find negative
} 
There are however a number of recent papers have looked at the effects of other types of affirmative action policies. Most closely related to our work is a wave of recent research looking at the introduction of political quotas in India. Chattopadhyay and Duflo (2004) show that increased representation of women in village councils in India affected policy choices in a way that is consistent with increased representation of female preferences. Considering the effectiveness of the policy with regard to improving opportunities for women more generally, Beaman et al (2009) show that increased female representation in the village councils reduced the gender gap in aspirations for both parents and adolescents; in addition, it erased the gender gap in education among adolescents. Given that they find no evidence of changing opportunities for women, they argue that this is primarily due to more role models for young girls. To the best of our knowledge, ours is the first paper examining the effects of a corporate board quota on female labor market outcomes.

\section{C. Gender Gap in Earnings in Norway}

Norway is generally considered to be progressive in terms of gender equality. Norway is characterized by generous health insurance, family leave, and childcare provision. According to the World Economic Forum Global Gender Gap Report, Norway is ranked number three in terms of opportunities for women, where the ranking takes into account economic, health, political, and educational opportunities. Despite this, a significant gender gap in earnings remains. ${ }^{9}$

While the earnings of women in Norway have been growing in the past few decades, the earnings of men appear to be have been growing even faster (see Figure 2). This disparity is larger (and grows) when we focus on individuals at the top of the income distribution. For example, looking at the $90^{\text {th }}$ percentile of earnings by gender, one sees that the gender gap has widened since 1995 . We see a similar pattern when we limit the sample to individuals with MBAs.

Note that in none of these trends do we observe evidence of a positive break for women after the board mandate. In our analysis below, we will consider whether any such break becomes visible when we focus on specific subsets of women who are most likely to be affected by the reform, either because they ended up on corporate boards, because they are employed by a company that increased female representation on its board, or because they have qualifications that closely mirror those of board members.

\section{Data}

Our primary data source is the Norwegian Registry data, a linked administrative dataset that

effects on firm performance in France and Belgium (although not statistically significant in Belgium) and positive effects on firm performance in Italy and Spain (although not statistically significant in Spain).

${ }^{9} \mathrm{http}: / /$ reports.weforum.org/global-gender-gap-report-2016/ 
covers the population of Norwegians between the ages of 16 and 64 for the years 1986-2014, and is a collection of different administrative registers, such as the education register, the family register, and the tax and earnings register. These data are maintained by Statistics Norway and provide comprehensive information about educational attainment, labor market status, earnings, various demographic variables (including age and gender), as well as information about family members.

For each individual in the labor force, we are able to identify the firm at which the individual is working in a given year. Hence, we are able to observe the entire Norwegian-based workforce of a given firm. We can also merge this data to different firm-level data sets maintained by the Norwegian Business Register ("Bronnoysund Registrene"). One such dataset is The Register of Company Accounts, which contains extensive information on the balance sheets of Norwegian firms. Furthermore, we obtain information from the Register of Business Enterprises on direct owner shares, the legal status of the business entity, as well as aggregate board composition (size and gender). Finally, starting in 1998, we are also able to merge in administrative data on individual appointments to boards of directors to the Norwegian Registry data. We can thus identify the specific individuals in the Norwegian Registry who are directors of an ASA firm in a given year, and individuals that are board members in AS firms (private limited liability companies).

\section{How did the Quota Affect Gender Differences on Corporate Boards?}

The employers' federation (NHO) and many business leaders were against a mandatory quota. While the NHO's main argument against the law was that it interfered with the shareholders right to appoint board members, businesses' main argument against the law was that there were not enough qualified women to serve on the boards. ${ }^{10}$ Therefore, we start our investigation of the effect of the reform by comparing women appointed to boards before and after the reform.

Table 1 shows the average characteristics of women and men who served on the board of directors of ASA firms before (1998-2003), during (2004-2008) $)^{11}$ and after (2009-2014) the Norwegian board reform. Panel A reports means for firms that were ASA in a given year. Because many ASA firms changed ownership status after 2003, and we cannot rule out the possibility that some of these changes were driven by quota avoidance, we also show statistics for the intent-to-treat group, namely the group of firms that were ASA in 2003, whatever their ownership status is thereafter (Panel B). ${ }^{12}$

\footnotetext{
10 These opinions were often quoted in newspaper articles around the time when the idea was first presented, for instance in the leading Norwegian business newspaper Dagens Næringsliv on February 22, 2002 (Egede-Nissen et al, 2002), and in the Guardian on August 1, 2002, (Osborn, 2002).

${ }^{11}$ Although technically the reform was completed by January $1^{\text {st }}$ of 2008 , to be conservative we include 2008 as a reform year.

${ }^{12}$ Stars in the table indicate that pre- (1998-2003) and post- (2004-2014) reform means are statistically different at the 5\% level of significance.
} 
Female board members are on average about 3 to 4 years younger than male board members, and that age gap did not change much post-reform. Similarly, there were no large changes in the relative share of married board members. However, we do observe a growing representation of board members with kids post-reform: while 49 (48) percent of male (female) board members had kids pre-reform, that share went up to 76 (75) percent post-reform.

Table 1a also shows absolute improvements in educational and professional backgrounds for women and decreases in some gender gaps post-reform. While the educational achievement of male board members did not change much after the reform, female board members in the post-reform period had completed almost a full extra year of education, and their education exceeds that of male board members in the post reform period. Most strikingly, while there were large gender gaps in the share of board members who had completed business or MBA degrees pre-reform, those gaps essentially disappeared post-reform.

For each board member, we also compute log (real earnings), earnings rank (either in their cohort, or in their cohort*education degree group) and whether the individual is among the top 5 earners in her or his firm the year prior to joining a board. We also calculate an overall index of board-related human capital. The index is a weighted sum of the many observable characteristics discussed above. To determine the weights, we use pre-reform data for men and calculate, using a linear probability model, which observable characteristics predict the probability of being on a board of directors of an ASA firm in the next three years. ${ }^{13}$ We estimate this linear probability model among men only in the pre-reform period (pre-2001). Then, using the estimated coefficients from the regression as weights, we compute the value of the index for all male and female board members in the year prior to an appointment to an ASA board position. This can be interpreted as the predicted probability of becoming a board member.

All of these metrics suggest improvement in the average quality of female board members postreform. Some, but not all, of these metrics also suggest convergence between the average male and female board members. For example, while only 44 percent of women on ASA boards pre-reform had earnings above the $90^{\text {th }}$ percentile in their cohort and degree group, that share went up to 52 percent post-reform; there was no change for men (61 percent pre-reform vs. 63 percent post-reform). On the other hand, while the level and rank of earnings increased in the post-reform period, it did so almost equally for men and women. Also, while the share of women coming from top positions in their firm after the reform increased by 6 percentage points, it is only slightly larger than the 5 percentage point increase among men. Similarly, the average female board member's gain in terms in terms of her board-specific human capital

\footnotetext{
${ }^{13}$ The observable characteristics we include are education degree, age, age squared, earnings rank within cohort and 5 lags of this variable, and finally degree type interacted with all of the following variables: the probability that you are above the $90^{\text {th }}$ percentile, the $95^{\text {th }}$ percentile, and the $98^{\text {th }}$ percentile in earnings within your cohort and five lags of each of these variables, an indicator of whether the individual is working and an indicator for out of the labor force and 5 lags of these variables.
} 
index roughly matches that for the average male board member. These conclusions are similar for the intent-to-treat sample (Table 1b).

To examine these changes more thoroughly, Figure 3 displays the full distributions of female board member characteristics before (1998-2003) and after (2009-2014) the quota. We include four variables: log of real earnings (Panel A), potential experience (age minus years of education minus five, Panel B), percentile rank of earnings within one's own cohort and education group (Panel C) and percentile rank of earnings within one's own cohort (Panel D), all computed prior to an appointment to an ASA board position. ${ }^{14}$ For these figures, we focus on ASA boards only. Consistent with the evidence when looking at the simple means, it is clear that the distributions of women's characteristics have shifted right for these important indicators of human capital (except potential experience).

Figure 4 displays the distributions of log (real earnings), earnings rank within education-cohort and board-specific human capital index for both male and female board members, pre- and post-reform. While these particular 3 metrics did not show convergence on means, it appears that the distributions more strongly overlap between male and female board members after the reform compared to the pre-reform period.

We also examined the characteristics of the newly appointed board members in each period, defined as those who were appointed to the board but have not previously served on a board (of either a public or private limited liability company) since 1998, when our board data begin. These results are presented in Appendix Table A3, while Figure 4 Panel D presents the distributions of the board-specific human capital index for newly appointed male and female board members, pre- and post-reform. By examining newly appointed board members, we are able to determine whether the quality of the marginal appointee is declining over time, consistent with the argument that fewer and fewer qualified women are available. The patterns we observe suggest the opposite is true: marginal new women board members are improving over time, with more education, higher earnings and greater board-specific human capital. In the post-reform period, there is essentially no difference between the human capital index of the average male new board appointee and the average female new board appointee.

Overall, the patterns discussed above appear inconsistent with firms' claims that they would be forced to appoint unqualified women to their boards because of a limited supply. The additional women appointed as a result of the reform were more qualified than the women who were already appointed before the reform. And, as the last three columns of Table 1 show, the average quality of board members, as expressed by the board-specific human capital index, increased throughout the period.

\footnotetext{
${ }^{14}$ Education groups are defined according to the 2-digit level of the Norwegian classification standard (NUS2000), which is close to the International Standard Classification for Education (ISCED97). The 2-digit level of NUS2000 has eight education levels and ten broad fields, which gives us 80 different education groups. We have reduced the number of education groups to 26 by combing all levels below lower secondary into one level instead of four, and not distinguishing between different broad fields for lower secondary education. For post-secondary education and above, we have defined eight broad fields instead of ten.
} 
Given the limited and declining number of ASA firms and the small average board size (Appendix Table A1), the total number of positions to be filled by women under the quota was quite limited. So, while it appears that firms were able to find qualified women to fill these reserved board positions, one may wonder how quickly quality constraints may have started to bind if more firms had been forced to abide by the quota. In other words: how large is the pool the women in Norway whose qualifications match those of male ASA board members? To try to address this question, we rely on the overall index of board-related human capital constructed above. With this index in hand, we compute the $25^{\text {th }}$, median and $75^{\text {th }}$ percentile of the index value among male ASA board members in 2003 (when the quota policy is announced) and 2008 (when the quota policy becomes compulsory). We can then count how many women in Norway in 2003 (or 2008) have a human capital index that is above the $25^{\text {th }}$, median or $75^{\text {th }}$ percentile of the male board members' distribution.

We find that, in 2003, over 5,000 Norwegian women had at least the qualifications of the median male board member and almost 45,000 women had the qualifications of the $25^{\text {th }}$ percentile male board member. The number of women with at least the qualifications of the $75^{\text {th }}$ percentile male ASA board member was 665 . By 2008, over 8,000 women have at least the qualifications of the median male ASA board member in that year and 610 have at least the qualifications of the $75^{\text {th }}$ percentile male. This suggests that there is, in fact, a substantial pool of qualified women. Assuming a board size of 5 (the median among ASA firms) and a quota policy requiring a minimum of two women on such boards, our estimates suggest that 2,500 (4,000) firms in 2003 (2008) could have been "served" with women whose observable quality is above that of the median male board member in that year. Of course, this back-ofthe-envelope exercise cannot account for a given qualified woman's willingness to serve on a board, and is subject to the recurring limitation of evaluating quality solely based on observable characteristics.

How did women appointed to boards fare after the reform? We next document post-reform changes in residual earnings between men and women while serving as board members by estimating the following equation:

$$
Y_{i t}=\alpha_{0}+\alpha_{1} \text { Female }+\beta X_{i t}+\lambda_{t}+\epsilon_{i t}
$$

where the outcome of interest is $\log$ (annual earnings) for individual $i$ in year $t, \lambda_{t}$ is a set of year dummies and $X_{i t}$ is a vector of individual controls (age and age squared, experience and experience squared). We estimate equation (1) separately for the pre-reform years (1998-2003), the reform years (2004-2008) and the post-reform years (2009-2014) using the population of individuals serving as board members in an ASA firm in a given year (Panel A) or in a firm that was ASA in 2003 (Panel B). To account for changes in the composition of ASA firms over time, we also estimate a version of equation (1) that includes board 
fixed effects, thus allowing us to focus on gender gaps in residual earnings among individuals that are serving in the same boardroom.

The results are reported in Table 2. In our preferred specification, which includes board fixed effects, we see that in the pre-reform period (column 4) women earned about 36\% less than their male counterparts (35\% among firms that were ASA in 2003). This gap fell to between 24 and $26 \%$ after the reform (column 6), depending on whether we look at ASA firms or at firms that were ASA in 2003. This difference between pre and post-reform gender gaps in earnings within boards is statistically significant at the $5 \%$ level in the case of ASA firms. Hence, post-reform, ASA boards became more equal not just based on the number of men and women sitting at the table, but also in the labor market earnings of these individuals.

While the results in Table 2 are consistent with the improved selection of female board members documented in Table 1, they may also reflect differences over time between the genders in the labor market premium associated with becoming a board member. To investigate this, we estimate the "premium" associated with becoming a board member and how this premium has changed over time for men and women. Specifically, we select the sample of individuals who were ever board members over the sample period (1998 to 2014) and estimate the following equation separately for the pre-, during- and post-reform periods:

$$
Y_{i t}=\alpha_{0}+\alpha_{1} \text { Board }_{i t}+\beta X_{i t}+\gamma_{i}+\lambda_{t}+\epsilon_{i t}
$$

where $Y_{i t}$ is the outcome for individual $i$ at time $t, \operatorname{Board}_{i t}$ is an indicator variable that equals 1 if individual $i$ was a board member of an ASA firm in year $t, X_{i t}$ is a vector of time-varying individual controls (age and age squared and experience and experience squared), $\gamma_{i}$ is an individual fixed effect, and $\lambda_{t}$ are year dummies. Standard errors are clustered at the individual level. Because our regression includes individual fixed effects, $\alpha_{1}$ captures the change in earnings associated with becoming a board member, or the "board premium." $" 15$ The two labor market outcomes we focus on are log (annual earnings) and the likelihood of being among the top 5 earners at one's company in a given year (a proxy for being in the "C-suite").

Table 3 presents the results separately for each outcome, gender and time period. Not surprisingly, there are substantial financial returns to being elected to a board of directors. Becoming a board member is associated with an increase in annual earnings of almost $10 \%$ for women and about $5 \%$ for men prior to the reform. Interestingly, this board premium fell for women during the transition period (from 10 to $7 \%$ ) but recovered somewhat in the post-reform period $(8 \%)$, although these changes are not statistically

\footnotetext{
15 The coefficient is also identified from changes in earnings that occur when individuals stop serving in boards.
} 
significant. In contrast, the premium increased among men (from 5 to $9 \%$ ). ${ }^{16}$ This suggests that convergence in earnings within boardrooms we observe in Table 2 might have been even larger if only driven by the improved selection of female board members.

Table 3 further shows that becoming a board member of an ASA firm is also associated with an increased likelihood of entering the C-suite of an organization. Women were more likely to enter the Csuite upon becoming a board member than men were, both before and after the reform, and this difference has not changed much over time.

\section{How did the Quota Affect Gender Gaps within Public Limited Liability Companies?}

Given the earlier evidence that ASA firms were able to find high-human capital women to assume the reserved board positions, we now turn to the question of whether the presence of these new female board members led to better opportunities for women working within these firms. Indeed, by forcing a higher representation of women in the corporate boardrooms of public limited liability companies, the quota policy may have spurred other changes within firms that benefitted female employees. For example, as a result of the reform, ASA companies may have hired more women to top management positions. This could have been the result of a new awareness of the existence of highly qualified women acquired during the search for female board members. Or perhaps women appointed to corporate boards can play a direct role in improving outcomes for other women within the organization: they may recommend more female candidates for top executive positions, and may be more favorably inclined towards these candidates. In addition, female board members may be more vocal in urging companies to adopt human resource policies that favor other women, such as tighter controls on pay, or more flexible work options for women, especially those with children. Such policies, if implemented, may increase the attractiveness of these companies for women and ultimately result in a greater female employment share.

On the other hand, some might argue that changes in the female representation in the boardroom will not translate in further gains for women within the organizations. One reason could be that corporate boards just do not matter much. ${ }^{17}$ In particular, boards may have little say in recruiting decisions or human resource policies. It is also possible that while boards matter, a $40 \%$ quota does not give women a majority opinion in board decisions, limiting their influence on corporate policies. This could translate into no

\footnotetext{
${ }^{16}$ This increase is consistent with the broader nationwide changes observed in Figure 2, which show an increase in gender gaps in earnings, particularly during the reform years.

${ }^{17}$ A large literature in corporate finance, most of it admittedly based outside of Norway, has studied what directors do in practice, and whether board of directors matter at all. In surveys about their main roles and responsibilities (Demb and Neubauer 1992), a majority of directors emphasize "setting the strategic direction of the company" and "set strategy, corporate policies, overall direction, mission, vision" as key aspects of their job. While most of the empirical work trying to determine the impact (if any) of boards on firm policies and performance has been hampered by endogeneity issues, this work has identified systematic correlations between features of the board (such as board size, share of outside directors, diversity, staggered boards, worker representation, etc.) and various firm outcomes (see Adams et al (2010) for a review).
} 
change for women within affected firms, or even a backlash by the remaining men on the boards. Because they are more risk-averse or less willing to compete (Niederle and Vesterlund, 2007), female board members may also be less eager to try to exert influences on firm decisions than their male counterparts. Finally, while women are presumed to recommend and favor candidates of their own gender for an appointment or a promotion, this might not be the case in practice. In an interesting paper, Bagues and Esteve-Volart (2010) study the decisions of recruiting committees for 4 main Corps of the Spanish Judiciary. Because the allocation of (male and female) candidates to committees is random, they can study how the gender composition of the committee affects hiring. They show that female candidates are significantly less likely to be hired when the share of female recruiters is relatively higher, and suggest that female majority committees tend to overestimate the quality of male candidates.

We bring all of these considerations to the data by examining whether there is any evidence of improvement in women's outcomes in the ASA companies that were mandated to increase female representation on their board. The particular outcomes we focus on include the female employment share as well as the employment of women with MBAs. We also study women's representation at the top of these organizations: we consider women's representation in the highest paid and five highest paid jobs within these organizations, or at the top of the income distribution within these organizations (top income vigintile, decile, and quartile). To account for possible changes in human resource policies to improve family-work balance, we also consider the representation of women with kids, as well as the representation of women working part-time.

Our identification strategy is similar to that in Stevenson (2010) and Ahern and Dittmar (2012). We use the pre-reform variation in female board representation across public limited liability companies (which we define as the 2003 share) to capture exogenous variation in mandated changes in the proportion of female board members. The logic of this identification strategy is simple. The ASA companies that started with a higher share of women on their board prior to the reform had to make smaller changes to their boards to comply with the law, while those that started with a smaller share had to make larger changes. In particular, focusing on the 2003-2014 time period, we estimate the following baseline regression:

$Y_{j t}=\alpha_{0}+\alpha_{1}$ FemaleBoardShare $_{j t}+\gamma_{j}+\lambda_{t}+\epsilon_{j t}$

where $Y_{j t}$ is the measure of female representation in firm $j$ at time $t$ (such as the share of female employees, or the number of women among the top 5 earners in firm $j$ at time $t$ ), FemaleBoardShare Fit $_{\text {is }}$ the percentage of female board members in firm $j$ at time $t, \gamma_{j}$ are firm fixed effects, and $\lambda_{t}$ are year fixed effects. We instrument for FemaleBoardShare ${ }_{j \mathrm{t}}$ with FemaleBoardShare $_{j 2003}$ interacted with year fixed effects. 
The population of interest for this regression is the set of workers in the Individual Register who are employed by ASA companies. ${ }^{18}$ While isolating this population is in principle an easy task given the availability of firm identification numbers in the Individual Register, the task is complicated somewhat by the intricacies of corporate ownership structures in Norway. As documented in La Porta et al (1999), ownership pyramids are common in many developed economies outside the US, with a company at the top of a pyramid (often a holding company) having control on other companies lower in the pyramid.

Given this, we present two sets of results. The first set of results takes these ownership pyramids into account and maps each ASA company in each year to its business group, defined as the set of firms (and employees) that are ultimately controlled by this ASA company in that year. ${ }^{19} \mathrm{We}$ define the panel of business groups that have an ASA parent in 2003 and whose parent remains ASA thereafter as treated by the reform. Note that a given business group may acquire or divest some firms over time; therefore, the set of firms included in the treated business groups may vary from year to year. The second set of results ignores these ownership structures and treats each ASA firm as a stand-alone company, even if this firm ultimately controls other firms in the economy or is controlled, via ownership chains, by another firm. Here, we define the panel of firms that were ASA in 2003 and remain ASA thereafter as treated by the reform.

Because of the potential for selection out of ASA status induced by the reform, we also define intent-to-treat samples. At the business group level, the intent-to-treat sample is defined as the panel of business groups that have an ASA parent in 2003, whether or not these business groups remain ASA in subsequent years; furthermore, we hold business group structure fixed as of 2003, hence limiting any additional concerns about selective acquisitions and divestitures after the reform. At the firm level, the intent-to-treat sample is the panel of firms that were ASA in 2003, regardless of whether they remain ASA thereafter. ${ }^{20}$

\footnotetext{
${ }^{18}$ Note that because the Individual Register data only covers individuals physically working in Norway, our analysis below does not cover employees of Norwegian public limited liability companies based outside of Norway.

${ }^{19}$ In order to map each public limited company to the set of firms (and employees) in the Individual Register that are ultimately controlled by this public limited company, we proceed as follows. When firms submit their annual accounts to the Register of Company Accounts, they are required to disclose information about the largest corporate owner if this corporate owner holds more than, or equal to, $50 \%$ of the shares in the company. So for each worker in the Individual Register, we know whether his or her employer has a corporate parent that owns at least $50 \%$ of the shares. By tracing these ownership structures in the Register of Company Accounts, we can therefore identify the ultimate corporate owner of each firm in the Individual Register. Because an ASA company can itself ultimately be controlled by another ASA company, the sample of ASA companies whose board composition we exploit in this analysis is smaller than the full sample of ASA companies. Also, in some instances, the ultimate owner of a Norwegian firm is a foreign entity. In those instances, we assign control of that firm to the Norwegian company that is the highest up in the ownership chain; we include that firm, and its employees, in our sample if that ultimate Norwegian parent is ASA. The Register of Company Accounts is available from 2002 to 2014.

${ }^{20}$ Appendix Table A4 offers some perspective on how ASA employment compares to employment in the rest of the economy. In particular, we report employment in ASA business groups (and ASA firms) versus outside of ASA business groups between 2002 and 2014, as well as the mean employee characteristics in these subsets. Over this time period, employment in ASA business groups accounts for about 5 percent of total employment. Employment in ASA firms only accounts for slightly more than 2 percent of total employment. ASA business groups and firms employ a lower share of women compared to the rest of the
} 
Appendix Table A5 summarizes our panel dataset, focusing on the treated samples (business groups or firms) for the time period 2003-2014. In particular, we confirm women's under-representation in the top corporate echelons. Only 13\% (11\%) of female employees are in the top quartile of the earnings distribution within their groups (firms); only 5\% (4\%) are in the top decile of the earnings distribution within their groups (firms). Only 5\% (6\%) of groups (firms) are headed by a woman. The number of women among the top five earners is on average .5 at the group level and .6 at the firm level.

Appendix Table A6 then provides some preliminary evidence on how our female representation outcomes have evolved over time (1998 to 2014), and in particular around the passage of the reform. We report yearly means for the female outcomes among the intent-to-treat sample of business groups (Panel A) and firms (Panel B). The data shows that all outcomes are trending positively for women since 1998. The data however does not show much evidence of a break-in-trend either when the policy is first announced (2003) or when the policy becomes compulsory (2008). The only exception might be related to the number of women among the top 5 earners, which might be growing faster after 2007.

We next turn to the formal analysis outlined in equation (3). Appendix Table A7 reports firststage regressions. The first four columns focus on the business group samples while the remaining four focus on the firm samples. Columns 1, 2, 5 and 6 are the treated samples; columns 3, 4, 7 and 8 are the intent-to-treat samples. In each column, the dependent variable is the percentage of women on the board of directors in the parent company (or firm) in a given year. The instruments are the percentage of women on the board in the parent company (or firm) in 2003 interacted with year dummies. All regressions include year dummies and parent company (or firm) fixed effects. Even numbered columns also control for the share of employment in a given year in each of 20 industry categories. Standard errors are clustered at the parent company (or firm) level.

The first-stage results are qualitatively comparable across all columns, and the signs and magnitudes on the instrumental variables are as expected. Parent companies or firms that started with a larger share of women on their boards increased the share of women on their board less throughout the quota treatment period. The point estimates indicate that the biggest adjustment to percentage female happened starting in 2007, right after the mandate became compulsory and the threat of dissolution was introduced. Not surprisingly, the point estimates on the instruments are always smaller in the intent-totreat samples than in the treated samples.

The main IV results showing the impact of the reform are in Tables 4 and 5. Both tables follow the same structure but Table 4 focuses on the business group-level analysis while Table 5 focuses on the

economy and are less likely to provide part-time employment. ASA business groups are three times more likely to employ individuals with MBAs, and three times more likely to employ women with MBAs. This implies that about $15 \%$ of individuals (men and women) with MBAs are employed at ASA business groups. Average employee earnings are more than $40 \%$ higher in ASA business groups compared to the rest of the economy. Employment at ASA firms is even more skewed towards the business educated and those with high earnings. 
firm-level. Results in Panel A relate to the treated samples, while results in Panel B relate to the intent-totreat samples. As noted earlier, each regression controls for time-varying industry composition. Observations are weighted by employment in the business group (Table 4) or firm (Table 5) in the baseline year (2003) to make the analysis representative of economy-wide impacts.

The first four outcomes we study relate to overall female representation. In particular, we ask whether a higher percentage of women on the board affects the share of employees who are women (column 1), women with MBAs (column 2), women with kids (column 3) or women working part-time (column 4). Neither table shows any systematic evidence of a positive impact of a mandated increase in the percentage of female board members on these outcomes. There is limited evidence of any consistent patterns (sign and significance-wise) across the 4 models we estimate.

In columns 5-10 of Tables 4 and 5, we consider possible impacts on the set of women who might be finding their way into the upper parts of the earnings distribution within their organization as a result of the quota policy. In particular, for each organization-year, we compute the fraction the female employees whose earnings are above the $75^{\text {th }}, 90^{\text {th }}$ or $95^{\text {th }}$ percentile of the organization-year distribution of earnings, and ask whether a greater percentage of women on the board increases female representation in those top earnings layers. In the even columns (columns 6, 8, and 10), we also control for a set of time-varying organization characteristics, such as the share of employees that are women of different educational backgrounds (including the share of employees who are women with MBAs). ${ }^{21}$ While some of these controls are clearly endogenous, a specification that includes them allows us to account for women's representation in the top corporate echelons conditional on some human capital measures (in the spirit of the measurement of gender discrimination in the labor market).

Again, we do not find any evidence consistent with the view that women gain greater representation in the upper echelons of their organization when the share of women on the board of directors increases. In fact, nearly all the point estimates are negative across all 4 models, and some of them (see in particular female representation in the top quartile of the earnings distribution) statistically significantly so. To get a sense of magnitude, consider for example column 6 of Table 5, Panel A. The estimated coefficient suggests that an increase in the share of women on the board from 5 percent (the pre-

\footnotetext{
${ }^{21}$ The full set of time-varying organizational controls is: employee average age; share of employees with: lower secondary education, post-secondary education (no college), undergraduate education, graduate education, post-graduate education; share of employees that are women with: lower secondary education, post-secondary education (no college), undergraduate education, graduate education, post-graduate education; share of employees with MBAs; share of employees that are married; share of employees with kids; share of employees that are women with MBAs; share of employees that are married women; share of employees that are women with kids.
} 
reform mean) to 40 percent may have reduced the share of female employees who are in the top quartile of the earnings distribution by $.07 * .35$, or about 2 percentage points.

We might expect corporate boards to exert the largest possible influence on the appointment of Csuite employees. Indeed, boards are generally responsible for appointing (and firing) the CEO of the company. While our data does not allow us to directly identify who is in the C-suite, we proxy for it by isolating individuals who are either the top earner (likely the CEO) or among the top 5 earners within the organization (business group or firm) in a given year. We then ask whether the likelihood that the organization has a woman as the top earner, or whether the number of women among the top five earners, is positively affected by the percentage of women on the board. The last 4 columns in Tables 4 and 5 study those outcomes. In this case, we equally weight each organization-year observation, as the number of individuals affected in the economy is unrelated to the size of the organization. We also present a specification that controls for the time-varying organizational characteristics discussed above.

Again, we fail to find evidence of any systematic positive impact of a mandated increase in the percentage of female board members on these outcomes. In fact, many point estimates are negative, and none is statistically significant. We note though that the standard errors are very large and thus we cannot rule out meaningful positive effects.

The main threat to our identification strategy is the possibility that groups and firms that started with different shares of women on their board in 2003, and were thus differentially impacted by the reform, were also on different time trends - specifically, we might expect firms that had a larger share of females were more "pro-female" and thus had greater improvements in female related outcomes, in which case we are likely to find negative effects of the reform. The remaining discussion in this section evaluates this threat.

Appendix Table A8 compares female representation between ASA groups and firms that start with a lower vs. higher baseline (2003) share of women on their board. In particular, limiting the time period to the pre-reform years 2002-2003, we regress our key set of indicators for female representation in ASA business groups or firms calculated in 2002 on the percentage of women on the board in 2003. We restrict the sample to business groups that were ASA in both 2002 and 2003 (Panel A) and firms that were ASA in both 2002 and 2003 (Panel B). When we do this, we see that firms with a greater female share in 2003 are in fact more pro-female. ${ }^{22}$

\footnotetext{
${ }^{22}$ Business groups that started with a greater share of women on their boards have a greater share of women, a greater share of women with MBAs and a greater share of women with kids among their employees pre-reform. Those business groups are also more likely to have a woman as the top earner. ASA firms with a greater share of women on their boards in 2003 are also more likely to have a woman as a top earner. On the other hand, we observe no statistically significant differences in the share of women in the top quartile, top decile, or top vigintile of the earnings distribution pre-reform, or in the number of women in the top 5 , as a function of the percentage of women on the board in 2003. However, the point estimates are all positive, consistent with women being more represented in the upper part of the earnings distribution in these organizations pre-reform.
} 
However, while this suggests that the two types of groups and firms may look somewhat different prior to the reform, given our reliance on organization fixed effects throughout our analysis, what is more relevant is whether ASA business groups or firms that had a greater share of women on their board in 2003 were on different time trends prior to the reform period. This is investigated in Appendix Table A9. The sample in Panel A includes all business groups that were ASA in 2003, while the sample in Panel B includes all firms that were ASA in 2003. Both samples cover the time period 1998-2003. Unlike in Appendix Table A8, this specification includes parent company (or firm) fixed effects. Of interest is the estimated coefficient on percentage women on board in 2003*year, where year is a linear time effect. We observe no statistically significant difference in time trends pre-reform across the set of indicators for female representation in the top corporate echelons (last 5 outcomes) and share of employees that are MBA women. However, there is some statistical evidence of different time trends for 2 outcomes in Panel A (share women with kids and share women working part-time) and one outcome in Panel B (share women). Two of these suggest that the growth in that particular outcome was smaller for firms that started with high female shares, rather than greater, thereby possibly biasing upwards the IV estimates. However, the positive coefficient for share women with kids in column 3, Panel A puts into question the interpretation of the negative point estimate in column 3 of Table 4, Panel B.

While overall reassuring, the results in Appendix Table A9 push us to investigate further the credibility of our IV results by studying the reduced form results behind this IV analysis, extending the time period as much as possible (e.g. 1998). In particular, in a regression that controls for business groups (or firm) fixed effects and year fixed effects, we interact percentage women on board in 2003 with a dummy variable for the pre-reform period (1999 to 2003), a dummy variable for the transition period (2004 to 2008) and a dummy variable for the post reform period (2009 to 2014). Each of these interaction terms can then be read as differential outcomes during that particular time period compared to the baseline year (1998). Table 6 reports the findings of this exercise. For space reasons, we present this analysis for the intent-to-treat groups only.

Overall, the findings in Table 6 seem to reinforce a causal interpretation of most of the findings in Tables 4 and 5. Consider first Panel A (intent-to-treat ASA business groups). As expected from Appendix Table A7, we see little evidence of pre-trends. Moreover, across outcome variables, formal tests cannot reject the hypothesis that the estimated coefficients on percentage women on the board in 2003 interacted with the pre-reform period (1999 to 2003) and percentage women on board in 2003 interacted with the post-reform period (2009 to 2014) are the same. (P values for this test are reported under each regression in Table 6.)

Panel B (intent-to-treat ASA firms) shows somewhat richer dynamics. Recall that the only robust evidence of impact in Table 5 was related to a decrease in the share of women in the top quartile (and 
maybe in the top decile) of the income distribution as the percentage women on the board increases. Columns 5 and 7 in Panel B of Table 6 provides support for the causal interpretation. In particular, there is no apparent pre-trend, and the largest impacts appear in the post-reform period (2009-2014).

To summarize, our analysis in this section fails to find much evidence of a positive impact of greater female representation on corporate boards for the outcomes of women employed in these organizations. In fact, the most robust results in this analysis suggest some possible negative effects on women's representation in the top quartile of the organizations' income distribution as these organizations brought more women to their boardroom. While we cannot uncover the specific mechanism(s), other research has also found such counter-intuitive impacts in other contexts (Bagues and Esteve-Volart, 2010). Overall, our analysis suggests that one should not expect the quota policy to generate large positive spillovers on the much larger set of women working for the organizations affected by the policy, at least in the short to medium term.

\section{How did the Quota Affect Gender Gaps at the Top of Labor Market?}

The ultimate goal of the reform was to improve labor market opportunities for all professional women, not just for those sitting on boards. In the previous section, we examined outcomes for one group that might indirectly benefit from the gender board quota: women employed in firms that were required to comply with the quota. In this section, we consider another set of women who might have indirectly benefitted from the reform: highly qualified business women whose credentials mirror those of board members, even if they themselves have not (yet) been appointed to a board. For a set of reasons, the mandate may have indirectly resulted in improved labor market outcomes for these women. First, to the extent that board membership is an attractive prize (see Table 3), the reform generates additional motivation to remain on the business fast track as the odds of winning this prize increased, even if the limited number of board positions in total might temper any such effect. Second, since the search for female board members may have helped bring these qualified women to the attention of businesses (because many of these women may have been featured in the database), this may have reduced search frictions in the filling of other executive positions by women throughout the economy, and thus broken the cycle of dependence on old business networks. Third, the newly appointed female board members, if not recommending these women exclusively for a position at their firm, may have been in a superior position to spread information about them throughout the broader Norwegian corporate sector. Finally, the increased demand for this type of women may have driven their wages up, even if they are not ever appointed to a board. To determine such possible effects, we follow a cohort approach and ask whether the gender gap for these highly skilled women in the post-reform cohort is smaller than in previous cohorts. 
There is no unique way to define the set of highly qualified women in the business sector who might have benefitted from the quota reform without having been appointed to the boards of ASA firms. We consider two different definitions. First, we use the predicted probability of board membership constructed in Section 3 (board-specific human capital index) to define the group of women who are most similar to women on boards, and thus most likely affected. This measure is estimated by predicting board membership based on observables for men in 1998-2003. Using the coefficients from this regression, we generate the predicted probability of board membership for all individuals and years based on observables. We then define the targeted group as those individuals with the highest predicted probability of becoming board members and construct 4 cohorts of such targeted groups. In particular, we define the affected groups as individuals with a probability of becoming a board member above the $99.5^{\text {th }}$ percentile of the propensity score in 1993, 1998, 2003, and 2008. ${ }^{23}$ Having identified these individuals in each cohort, we follow their earnings for 5 years. We thus have two pre-reform cohorts (individuals identified in 1993, who we follow from 1994 to 1998, and individuals identified in 1998, who we follow from 1999 to 2003), a reform cohort (individuals identified in 2003, who we follow from 2004 to 2008), and a post-reform cohort (individuals identified in 2008, who we follow from 2009 to 2013).

Given the ultimately arbitrary nature of this sample definition, we also report results using an alternative definition: we select in 1993, 1998, 2003 and 2008 all individuals with a business degree, graduate or undergraduate, whose earnings were above the $98^{\text {th }}$ percentile of the earnings distribution (of individuals with the same education and experience) in each of the three preceding years. Again, this results in 4 cohorts of individuals who are each tracked for 5 years. In the implementation of both definitions, we restrict ourselves to men and women who are between the ages of 35 and 55, because most board members fall within this age group (See Appendix Figure 1). Specifically, we estimate the following equation:

$$
\begin{aligned}
Y_{i t}= & \alpha_{0}+\alpha_{1} \text { Female } * \text { Pre }_{i t}+\alpha_{2} \text { Female } * \text { Post } 1+\alpha_{3} \text { Female }_{i} * \text { Post }_{i t}+\delta \text { Female }+\beta X_{i t}+ \\
& \lambda_{t}+\epsilon_{i t} .
\end{aligned}
$$

\footnotetext{
${ }^{23}$ Appendix Figure 2 shows how the predicted probability of becoming a board member changes for the reform cohorts (2003 and 2008) as a function of this propensity score. In the spirit of a regression discontinuity, we regress an indicator for being an ASA board member, on the propensity score, the hypothesized cutoff, a treated (or post) dummy, and the interaction of the cutoff with post. Each point represents the difference in the probability of board membership between those with predicted probabilities above and below the cutoff after the reform. The plot begins at 95.1 percentile and, for this first point, the control group is the 95.0 percentile. To select the cutoff we note that if the "true" cutoff were at the $96^{\text {th }}$ percentile for instance, then the graph would show a peak exactly at the $96^{\text {th }}$ percentile (see Appendix Figure 3). The figure shows that at the lower levels (95.1-99.0), there is little difference between the probability of board membership after the reform for those above and below the cutoff, although it is slowly rising with the percentile (as one might expect). However, there is a clear increase in the difference after the $99^{\text {th }}$ percentile, although there is no peak. This suggests that the affected group is smaller than the $99^{\text {th }}$ percentile.
} 
where $Y_{i t}$ is the outcome of interest (log of earnings or an indicator for being among the top 5 earners at one's firm), Prel is an indicator for the cohort just prior to the reform (1999-2003), Post1 is an indicator equal to one for the reform cohort (2004-2008), and Post2 is an indicator equal to one for the post-reform cohort (2009-2013). The omitted category is the earliest cohort (1994-1998), $X_{i t}$ refers to time varying individual characteristics (age and age squared, potential experience dummies), and fixed individual characteristics (an indicator for whether the individual was working at the time of selection into his or her cohort, as well as marital status and presence of children at the time the individual was selected into his or her cohort). We control for year dummies $\left(\lambda_{t}\right)$ and cluster the standard errors at the person level. The coefficient $\delta$ measures the gender gap in years (1994-1998), and we expect it to be negative; that is, women earned less than men for this earliest cohort. The as estimate the change in the gender gap for each consecutive cohort, relative to this baseline.

Table 7 presents the results for the gender gap in earnings while Table 8 presents the results for gender gaps in presence in the "C-suite." 24 There is a gender gap in earnings in the baseline period (19941998), with women in these very positively selected groups earning between 13 and $16 \%$ less than the men (Panel A). Relative to this baseline, these gaps shrank before the reform (1998-2003), were unchanged or growing during the reform period (2004-2008) and shrank again after 2009. But the postreform coefficients, while positive, are all statistically insignificant. Moreover, the coefficients for the post-reform cohorts are similar in magnitude to those for the more recent pre-reform cohort. Finally, if we drop from the sample individuals who serve on boards (those directly affected) then the estimated gaps for the reform and post-reform period are small (and in a few cases negative) and remain statistically insignificant; the point estimates suggest worse outcomes for the reform and post-reform cohorts than for the most recent pre-cohort. Thus, although women newly appointed to boards do benefit from the mandate, there is no evidence of benefits among those women not directly affected but whose credentials mirror those of board members. Nor is there any evidence that such benefits are "emerging."

While our analysis is restricted to very small and highly selected groups of top male and female earners, it is still possible that men and women within those selected groups are not directly comparable to each other. More importantly, the baseline gender differences between males and females might differ across the 4 cohorts. Thus, in Panel B, we re-estimate equation (5) controlling for each individual's log annual earnings in the year prior to the beginning of his or her cohort (1993 for the 1994-1998 cohort; 1998 for the 1999-2003 cohort; 2003 for the 2004-2008 cohort, and 2008 for the 2009-2013 cohort). The

\footnotetext{
${ }^{24}$ Because we are stratifying our sample based on the predicted value of the becoming a board member, which is a function of the previous 3 years of earnings, our second post-reform cohort is selected based on post-reform characteristics. As an alternative specification, we also estimate the effects when we break the sample into only two periods - a pre-reform period (identified in 1992, followed from 1993 to 2003) and a post-reform period (identified in 2003, followed from 2004 to 2014), where individuals are stratified based only on pre-reform characteristics. The results when we estimate Tables 7 and 8 with this two-cohort stratification are presented in Appendix Table A10. These results are similar.
} 
average gender gap in earnings that emerges between men and women in the baseline cohort is smaller under this alternative specification (reaching at most 5 percent, column 2). Again, there is little evidence of any substantial changes from the earliest cohort (1994-1998), and most coefficients are insignificant (except for one that has a negative sign). Overall, the results in Panels A and B suggest little evidence of any improvement for these groups of women, especially when we restrict the analysis to individuals who did not mechanically benefit from the quota. However, we should note that the standard errors are large and we cannot reject reasonable size effects.

A possible problem with the exercise so far is that it might just reflect general trends occurring in Norway's labor market - for instance, Figure 2 shows that gender gaps increased during the reform period across the board, possibly reflecting factors other than the reform. To assess this, we would ideally compare the "affected" groups with a similar group that was not affected. This exercise is difficult since there is no clean way to define the affected group to begin with. Nevertheless, we conduct additional tests on slightly less-select groups of men and women (defined as individuals in the $90^{\text {th }}-99^{\text {th }}$ percentile of the human capital index and individuals in the $99-99.4^{\text {th }}$ percentile of the human capital index) to provide some counterfactuals.

The results for the counterfactual groups are presented in the last 2 columns of Table 7 . We find that the gender gap in earnings fell in the post-reform cohort for these less affected groups-and for the broader $90-99^{\text {th }}$ percentiles the effects are positive and statistically significant. If we see these groups as pure controls (something we are reluctant to do given the discussion above), then a triple-difference estimate would suggest even smaller effects of the reform. These findings underscore our conclusion that there does not appear to be any significant effect of the reform for women at the very top.

Despite no clear sign of reduced gender gaps in earnings, it is possible that the reform improved the representation of women in top positions within firms. In Table 8, we estimate gender gaps in the probability of being one of the top 5 earners within a firm. As in Table 7, the evidence in Table 8 suggests no systematic improvement in female representation in the $\mathrm{C}$-suites of corporations once we drop board members from the sample. In other words, any improvement in outcomes for women at the very top seem to be concentrated among the women who are directly affected by the reform: that is the women who become board members. And again, the effects would be smaller or even negative if we were to use our counterfactual groups as controls.

\section{How did the Quota Affect Gender Gaps Among Young People?}

In a final step, we examine the effect of the reform for young individuals who are contemplating a career in business, are currently pursuing a degree toward such a career, or have recently started such a career. While there is no clean estimation strategy to assess the impact of the reform on this broader set of 
individuals, we combine time-series evidence, qualitative surveys and cohort analyses to document associations between the reform and young women's (and men's) choices, expectations, and early career outcomes.

We start by assessing whether the reform coincided with changes in the share of young men and women interested in pursuing a business degree. If the reform made business careers more appealing for women, then we might observe an increase in the fraction of women obtaining the degrees that lead to those careers. Figure 5 plots the gender gap in the likelihood of completing a business degree, or social studies, law or business degrees, over time, both for graduate students (Panel A) and undergraduates (Panel B). Among students with graduate degrees, we find no increase in the share of female majors in the post-reform period, regardless of our definition of "business-oriented" majors. ${ }^{25}$ Among students with undergraduate degrees, we do see a decline in the gender gaps that appears to coincide with the postreform period, although much of that progress is merely recovering from a worsening of the gap during the reform period itself.

Next, we look for evidence of any change in the gender gap in early career earnings among recent graduates of graduate business programs. We follow an empirical approach similar to that in Section 5 (Tables 7 and 8). We construct 4 cohorts of recent (within 3 years of completing their degree) male and female graduates from either a graduate business program or a graduate business, law, or social studies program, and study the gender gaps that emerge over a 5-year period. We include two pre-reform cohorts (1994-1998 and 1999-2003), a reform cohort (2004-2008), and a post-reform cohort (2009-2013).

Table 9 presents the results of estimating equation (4) for this sample of recent graduates. The gender gap in earnings among recent graduates in the baseline cohort (1994 to 1998) is very large, between 19 and 22\%. This gender gap is increasing in the most recent pre-reform period, as well as during the reform, while gender gaps in the post-reform cohort are comparable to that in the baseline cohort. Hence compared to their two closest cohorts, women seem to be faring better in the post-reform cohort, even if no better than in the baseline. A similar pattern holds when we focus on the last two years of each cohort. We do seem to find evidence of a reduced gender gap in earnings in the post-reform period, both among recent business graduates as well as among the broader group of business, law, and social studies degree earners.

However, these results are difficult to interpret as they could just be driven by overall trends. To assess this, we consider natural science graduates as a possible control group - this is a group of about the same size and one in which there are comparable gender gaps in the early 1990s. Individuals in this field are also highly paid, but they are much less likely to become board members: $72 \%$ of female board members with graduate degrees have a graduate degree in business, while only $22 \%$ had a graduate degree

\footnotetext{
${ }^{25}$ In Norway, as in the United States, undergraduates primarily choose their major once enrolled in college.
} 
in natural sciences. Gender gaps in science were shrinking at faster rates in all periods than for the affected business-oriented fields. It is clear that the improvements among the possibly affected groups over time are not limited to business fields, but are also occurring in other, non-business areas, raising doubts as to whether this pattern might be driven by the reform. Nevertheless, the findings in Panel A do raise the possibility that the reform benefitted young women starting their career in business.

Panels B and C of Table 9 look at trends in marriage and fertility. While we see some relative increase in marriage delay among young women with a background in business in the post-reform cohort, the patterns across cohorts for this group do not seem much different than the patterns for science graduates. Gender gaps in fertility patterns appear stable across cohorts, both for business graduates and science graduates.

Finally, to understand how young people's perceptions might have been affected by the quota policy, we also conducted an online survey of all current students (both male and female) at the Norwegian School of Economics, one of Norway's most prestigious business schools. Students received an invitation to answer the short survey; a total of 763 students responded out of 3,528. A bit more than half were women $(54 \%){ }^{26}$

Table 10 shows the distribution of responses by gender. The vast majority of students reported being aware of the reform ( $70 \%$ of women and $75 \%$ of men). About $50 \%$ of women expect their earnings to increase as a result of the reform, while $40 \%$ expect them to be unaffected. The remaining $10 \%$ expected a decline. Interestingly almost $30 \%$ of men expect the reform to lower their earnings while only $10 \%$ expect their earnings to increase, with the remaining $60 \%$ expecting no change. Similarly, most women $(70 \%)$ believe the reform will make it more likely that they will eventually be in top executive business positions, while $50 \%$ of men expect their chances to be in such positions will decrease as a result of the reform. Fewer than $10 \%$ of women report that the quota increased their motivation to obtain a business degree, and only $4 \%$ of men reported a decrease-consistent with our regression analysis showing no significant changes in the fraction of women choosing business-oriented degrees.

Despite the large share of female respondents who report expecting that the reform will improve their labor market outcomes, we find little evidence that these young women anticipate modifying their family plans as a result. When asked about their marital and fertility plans (whether and when to have children), almost all women reported that the reform left those plans unaffected-consistent with our findings from the Registry data in Table 9. This is particularly notable given that prior research suggests that childbirth might be one of the biggest hurdles to keeping women with a business degree on the fast track in their early years out of school, at least in the U.S. (Bertrand, Goldin and Katz 2011).

\footnotetext{
${ }^{26}$ Those completing the survey would be eligible to win one of 20500 NOK gift cards.
} 


\section{Conclusion}

This paper provides what we believe is the first effort to assess whether gender quotas in business can be an effective tool to reduce gender disparities in the corporate sector. The Norwegian approach, focused on mandating gender diversity on corporate boards, is important to study because it is being adopted by more and more countries throughout Europe. Our study of the "mechanical" effect of the quota offers optimism to supporters of this affirmative action policy. Despite businesses' fear that there were not enough qualified women to fill the board positions, the new reserved seats were filled with women who are observationally better qualified to serve on boards along many dimensions than women appointed prior to the quota, suggesting that previously untapped networks of top business women were activated by the policy. As a consequence, the gender gap in earnings within boards fell at the same time as the boards became more diverse. We view such a finding nearly as a necessary condition for the hope of any positive spillovers of the quota policy beyond its mechanical effect.

When looking for evidence of any such spillovers in the subset of the economy where we would expect them the most, the evidence is more discouraging. We see no evidence of improvements for women working in firms most affected by the reform, suggesting that the new female board members are not significantly changing the opportunities for women within the firm. Additionally, we find no evidence of effects on the set of highly qualified women who would be candidates for board positions, regardless of firm.

We also considered the possibility that the law was important in changing expectations, behaviors, and outcomes among the younger cohorts entering the corporate sector. Most interesting was qualitative evidence based on self-reported data. Career expectations of young women in business went up, with many viewing the reform as improving their future earnings or increasing the likelihood of making it to the very top corporate echelons. It is possible that the positive mindset the reforms induced among young women in business will ultimately encourage them to stay on the fast track for longer.

While it is likely too early to draw definitive conclusions, the evidence we report in this paper suggests that governments should be wary of placing too much faith in this specific affirmative action policy as a broad solution to the persistent under-representation of women in the top layers of the business sector. Yet, supporters of this policy will also see some positive takeaways in our results. First and foremost, businesses' main argument against the policy (lack of qualified women) appears weak in light of the fact that the newly appointed female board members were-on paper at least - more qualified than those appointed before; most likely, the reform spurred a more widespread search effort and helped break some of the "old boys" networks that may have dominated the board appointment process prior to the reform. Second, it is telling that young women preparing themselves for a career in business widely support the policy and perceive it as opening more doors and opportunities for their future career. Hence, 
it is possible that the reform might have broader long-term effects that we cannot observe just 7 years after the quota policy became compulsory. An evaluation in the spirit of this one should be repeated in a decade or so. However, because similar policies are currently discussed in many countries, we view this mediumterm evidence as relevant input into the law-making and policy-making processes. 


\section{Bibliography}

Adams, Renee B, Benjamin E. Hermalin and Michael S. Weisbach. 2010. "The Role of Board of Directors in Corporate Governance: A Conceptual Framework and Survey." Journal of Economic Literature, 48(1): 58-107.

Ahern, Kenneth, and Amy Dittmar, 2012. "The Changing of the Boards: The Impact on Firm Valuation of Mandated Female Board Representation”. Quarterly Journal of Economics, 127(1): 137-97.

Bagues, Manuel F., and Berta Esteve-Volart, 2010. "Can gender parity break the glass ceiling? Evidence from a repeated randomized experiment." The Review of Economic Studies, 77(4), 1301-1328.

Beaman, Lori, Raghabendra Chattopadhyay, Esther Duflo, Rohini Pande, and Petia Topalova, 2009. “Powerful women: Does exposure reduce bias?” The Quarterly Journal of Economics, 124: 1497-1540.

Bertrand, Marianne, Claudia Goldin, and Lawrence F. Katz, 2010. "Dynamics of the Gender Gap for Young Professionals in the Financial and Corporate Sectors." American Economic Journal: Applied Economics, 2(3): 228-55.

Catalyst. Pyramid: Women in S\&P 500 Companies. New York: Catalyst, March 1, 2017.

Chattopadhyay, R., and E. Duflo, 2004, "Women as Policy Makers: Evidence from a Randomized Policy Experiment in India." Econometrica, 72: 1409-1443.

Coate, S., and G. Loury, 1993. "Antidiscrimination Enforcement and the Problem of Patronization." American Economic Review Papers and Proceedings, 83(2): 92-98.

Comi, Simona, Mara Grasseni, Federica Origo, and Laura Pagani, 2016. "Where Women Make the Difference. The Effects of Corporate Board Gender-Quotas on Firms' Performance Across Europe.” Unpublished mimeo.

Criscione, Valeria. 2002. "Oslo's boardroom battle”, The Financial Times, March 13, p. 15, edition 34.

Demb. Ada, and F. Friedrich Neubauer. 1992. The Corporate Board: Confronting the Paradoxes.Oxford; New York; Toronto and Melbourne: Oxford University Press. 
Egede-Nissen, Heidi, Arne Grande, Åsne Haugli, Ingvild Rugland, Torstein Tranøy, and Morten Ånestad, 2002. “Kvoteforslag høster storm”, Dagens Næringsliv, February 26, page 10.

Eckbo, B. Espend, Knut Nygaard, and Karin S. Thorburn, 2016. "How Costly Is Forced Gender-Balancing of Corporate Boards," European Corporate Governance Institute (ECGI) - Finance Working Paper No. $\underline{463 / 2016}$.

European Union, 2016. "Gender balance on corporate boards. Europe is cracking the glass ceiling," Directorate-General for Justice and Consumers, Fact sheet, July 2016.

Ferrari, Giulia, Valeria Ferraro, Paola Profeta, and Chiara Pronzato, 2016. "Gender Quotas: Challenging the Boards, Performance, and the Stock Market,” IZA Discussion Paper No. 10239, September.

Heidenreich, Vibeke, 2010. "Rekruttering til ASA-styrer etter innføringen av kvoteringsregelen”, Magma, $7 / 2010$.

Hinnerich, Bjorn Tyrefors and Joakim Jansson, 2017. "Gender Quotas in the Board Room and Firm Performance: Evidence from a Credible Threat in Sweden," unpublished paper.

Johansen, Marius Apland, and Marius Javier Sandnes, 2008. "Gender equality in the boardroom: the Norwegian case of Rosa Parks? An event study", Master thesis, The Norwegian School of Economics.

Matsa, David A., and Amalia R. Miller. 2013. “A Female Style in Corporate Leadership? Evidence from Quotas.” American Economic Journal: Applied Economics, 5(3): 136-69.

Niederle, Muriel, and Lise Vesterlund. 2007. "Do Women Shy Away from Competition? Do Men Compete Too Much?” Quarterly Journal of Economics, 122 (3): 1067-1101.

Norwegian Ministry of Labor and Social Affairs, 2012. "Grunnlaget for inntektsoppgjørene 2012", Norwegian Official Report 2012:11, Oslo.

Nygaard, Knut, 2011. "Forced board changes: Evidence from Norway.” Norwegian School of Economics and Business Administration Discussion Paper Sam 5/2011. 
Osborn, Andrew, 2002. "Norway sets 40\% female quota for boardrooms. Companies insist too few qualified women are available to fill posts". The Guardian, August 1, http://www.theguardian.com/society/2002/aug/01/publicsectorcareers.genderissues

Pande, R., and D. Ford, 2011. "Gender Quotas and Female Leadership: A Review". Washington DC: Worldbank.

La Porta, Rafael, Florencio Lopez-De-Silanes, and Andrei Shleifer, 1999. "Corporate Ownership Around the World." Journal of Finance, 54(2): 471-517, 04.

Rao, Gautam, 2013. "Familiarity Does Not Breed Contempt: Diversity, Discrimination and Generosity in Delhi Schools," unpublished mimeo. https://sites.google.com/site/graoeconomics/

Stevenson, Betsey, 2010. "Beyond the classroom: Using Title IX to measure the return to high school sports." The Review of Economics and Statistics, 92: 284-301.

Storvik, Aagot, and Mari Teigen, 2010. «Women on Board. The Norwegian Experiment». FriedrichEbert-Stiftung, International Policy Analysis, http://library.fes.de/pdf-files/id/ipa/07309.pdf

Teigen, Mari, 2012. "Gender quotas on corporate boards: On the diffusion of a distinct national policy reform." Comparative Social Research, 29: 115-146. 


\section{Figure 1: Female Directors in ASA Firms}

\section{Percentage Female Directors in ASA Firms, 1998 to 2014}

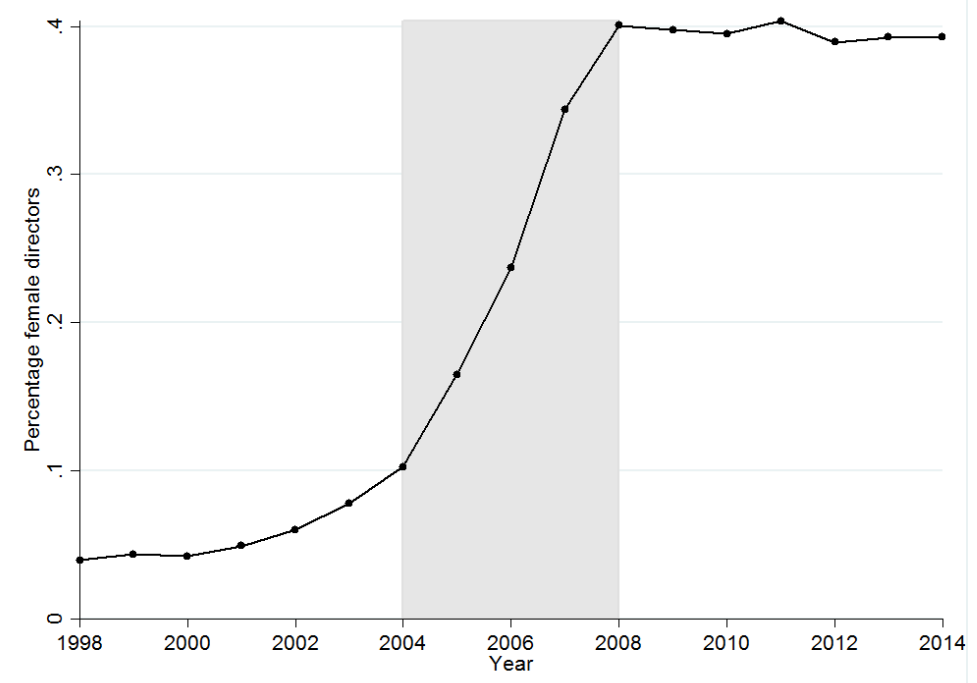

Distribution of Share Female Directors in ASA Firms, 2003 and 2009

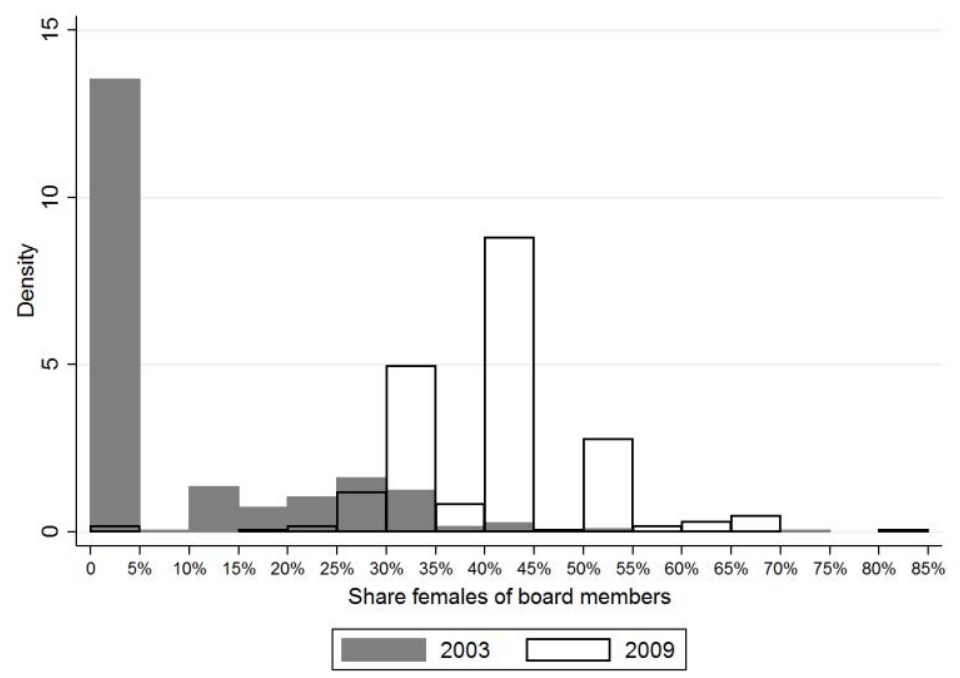

Note: The bottom figure shows the density of board with a female share of board members in the different bins as measured on the horizontal axis. i.e. between 0 and 5\%, between 5 and $10 \%$, between 10 and $15 \%$ etc. When board size is 4 or $6,50 \%$ must be females in order to comply with the law. When board size is $5,7,9$ or more, between 40 and $45 \%$ must be females in order to comply, whereas a female share of $37.5 \%$ is sufficient to comply with the law when board size is 8 , and finally $33 \%$ must be females in a board with 3 members. 
Figure 2: Earnings Gender Gap in Norway, 1985-2010

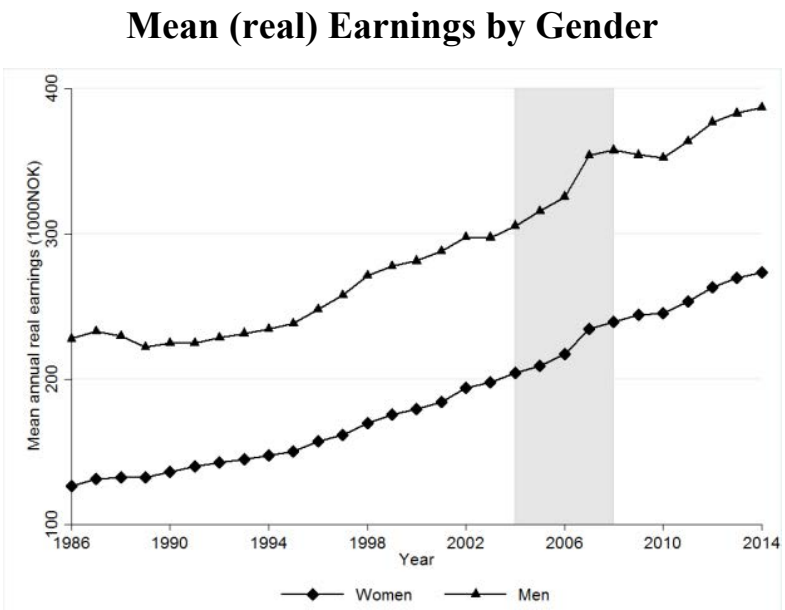

$90^{\text {th }}$ Percentile of (real) Earnings by Gender

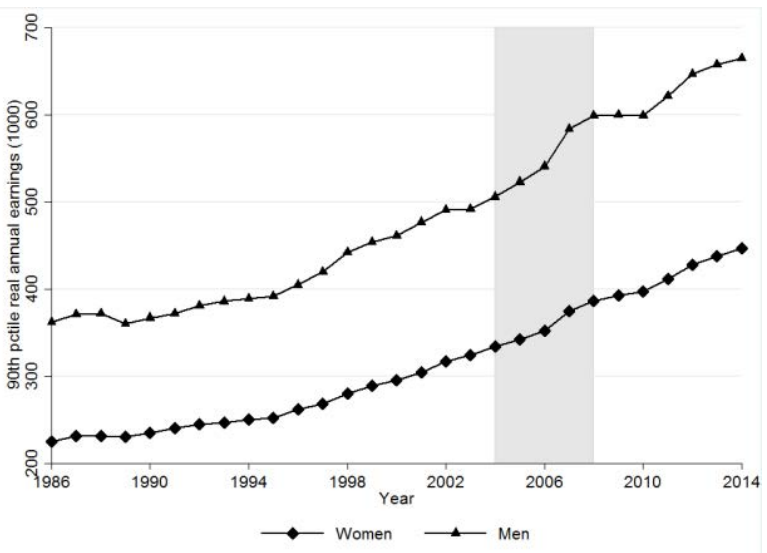

$90^{\text {th }}$ Percentile of (real) income among MBAs

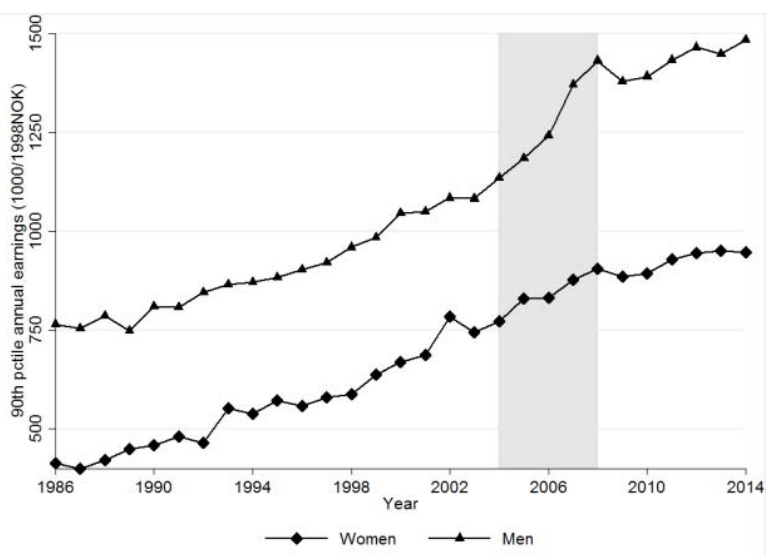

Note: The reform years (2004-2008) are shaded in grey. 
Figure 3: Economic Background of Female Board Members,

\section{Pre- (1998-2003) and Post- (2009-2014) Reform}

Panel A: Log of Annual Earnings before appointment

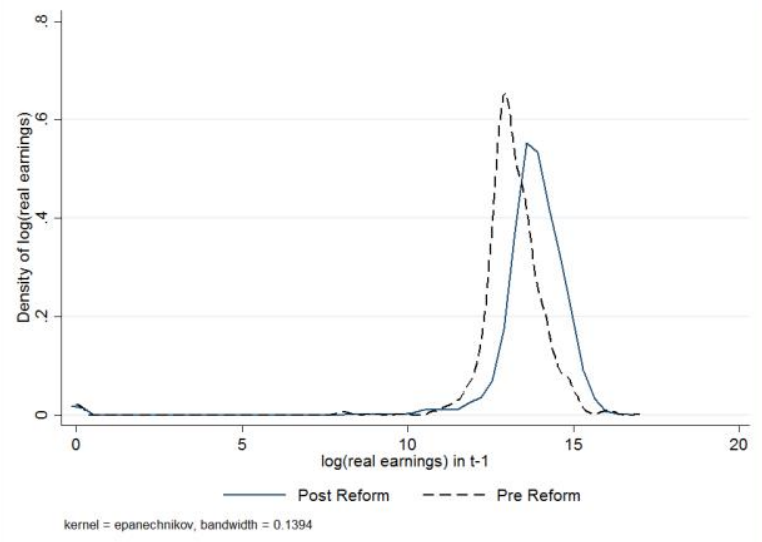

Panel C: Percentile of earnings within educationcohort before appointment

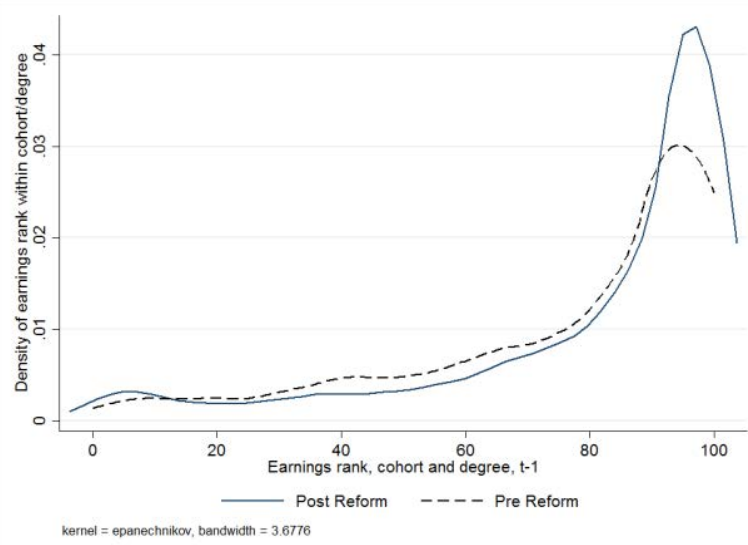

Panel B: Experience (in years) before appointment

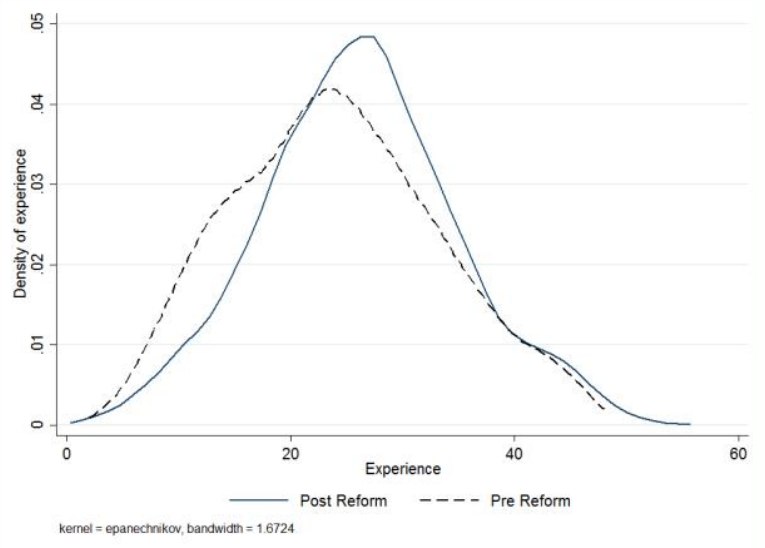

Panel D: Percentile of earnings within cohort before appointment

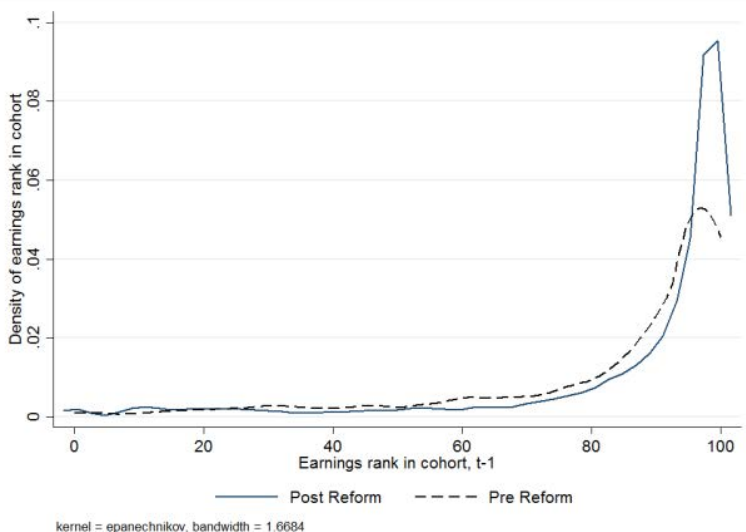


Figure 4: Economic Background of Male and Female Board Members

Before the Reform (1998-2003) $\quad$ After the Reform (2009-2014)

Panel A: Log of Annual Earnings before appointment
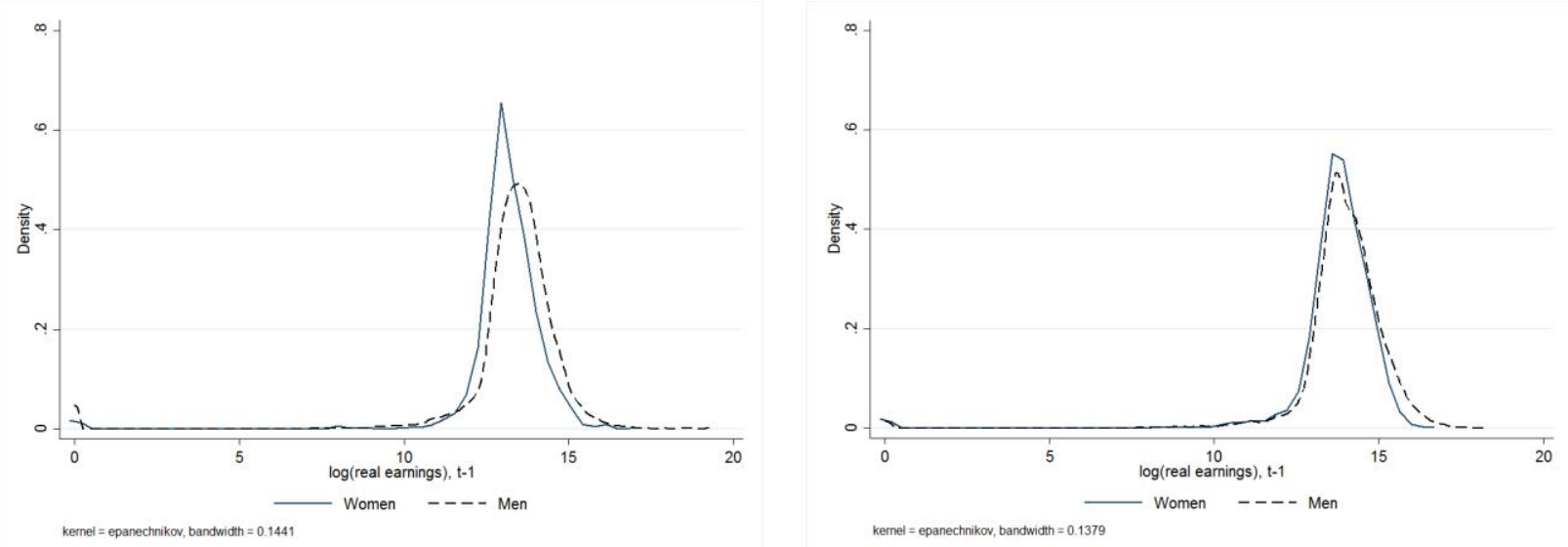

Panel B: Percentile of earnings within education-cohort before appointment
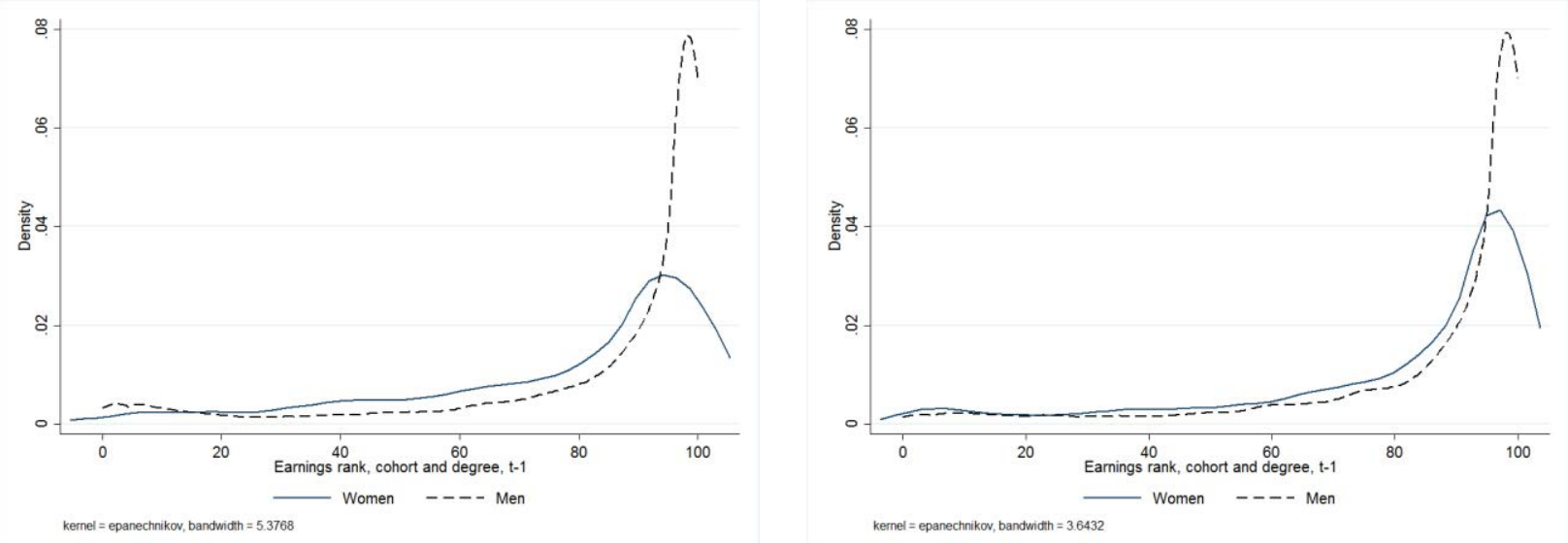
Panel C: Board-specific Human capital index
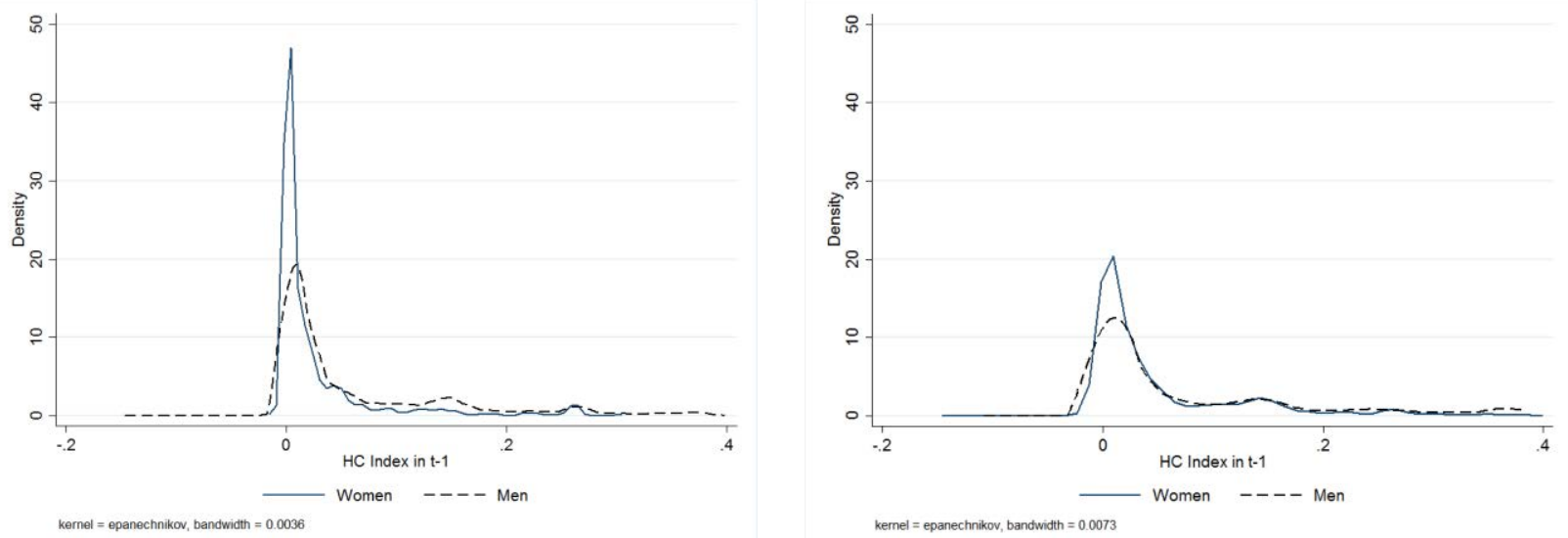

Panel D: Board-specific Human capital index of board members without previous board experience (neither on ASA or ASA boards)
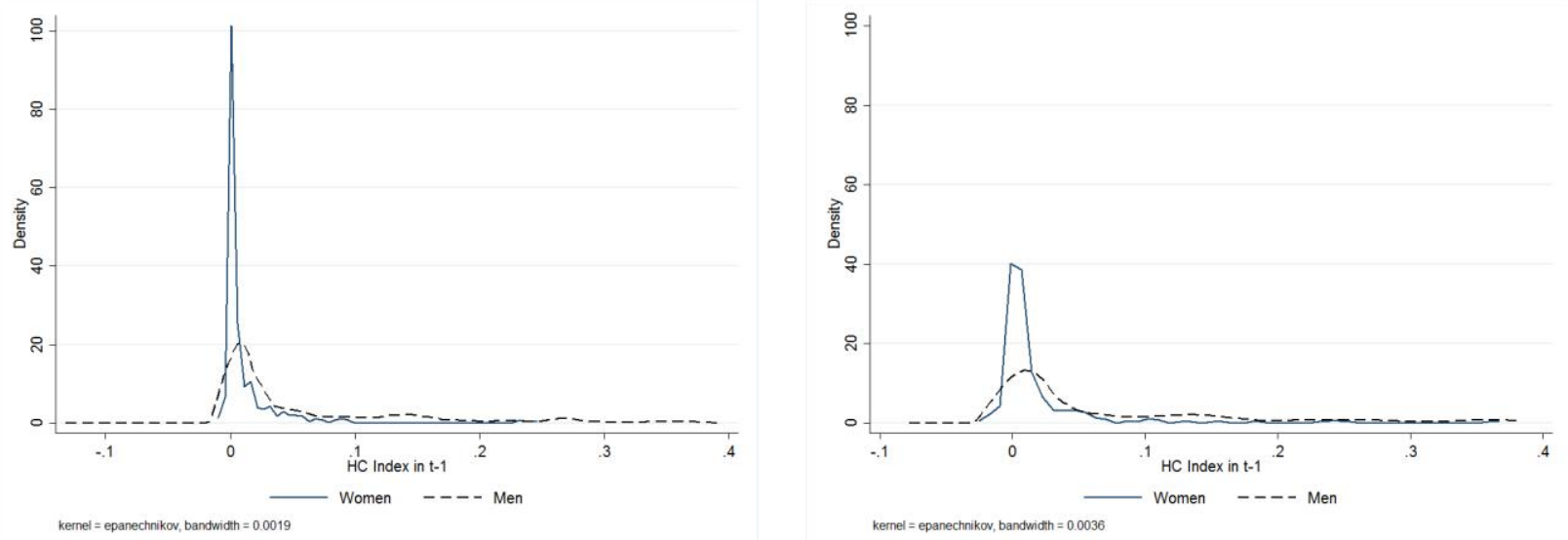
Figure 5: Gender Gap in Graduation from Business Programs, By Graduation Year

Panel A: Graduate Degree

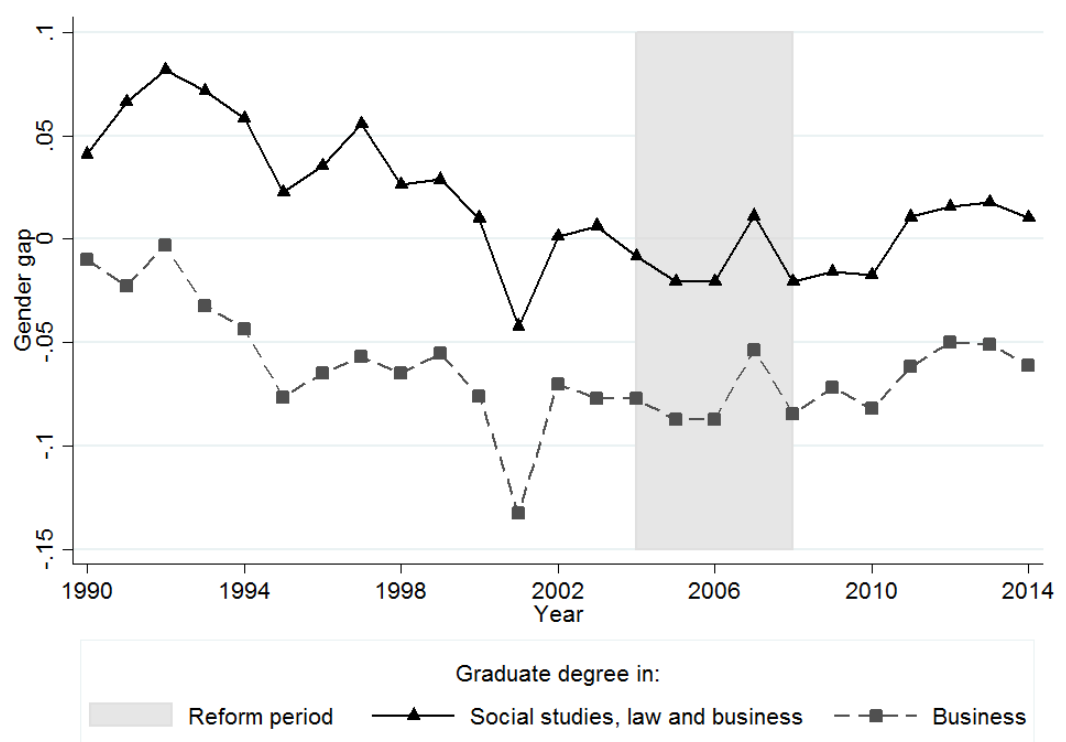

Panel B: Undergraduate Degree

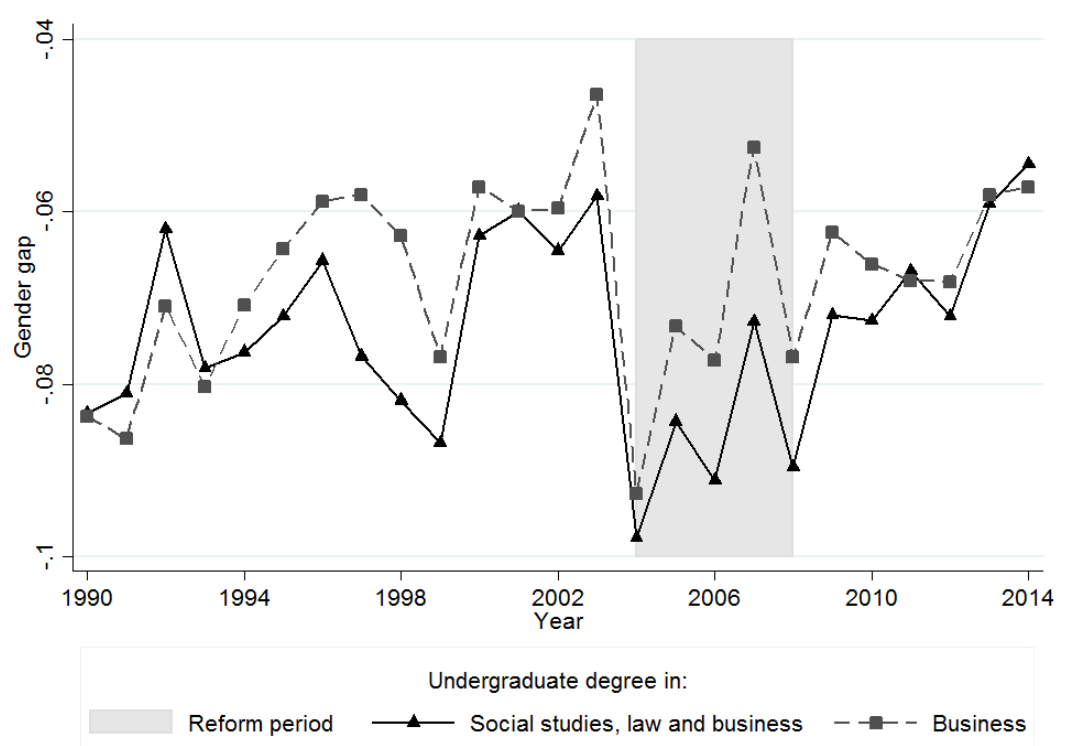

Note: The graphs report coefficient on female from year-specific regressions predicting whether individual i obtained a business (or a social studies, law or business) degree in that year. Dashed line reports the results for business degree and the solid line includes social studies and law in addition to business degrees. 


\section{Appendix Figure 1: Probability of Becoming an ASA Board Member, By Age}

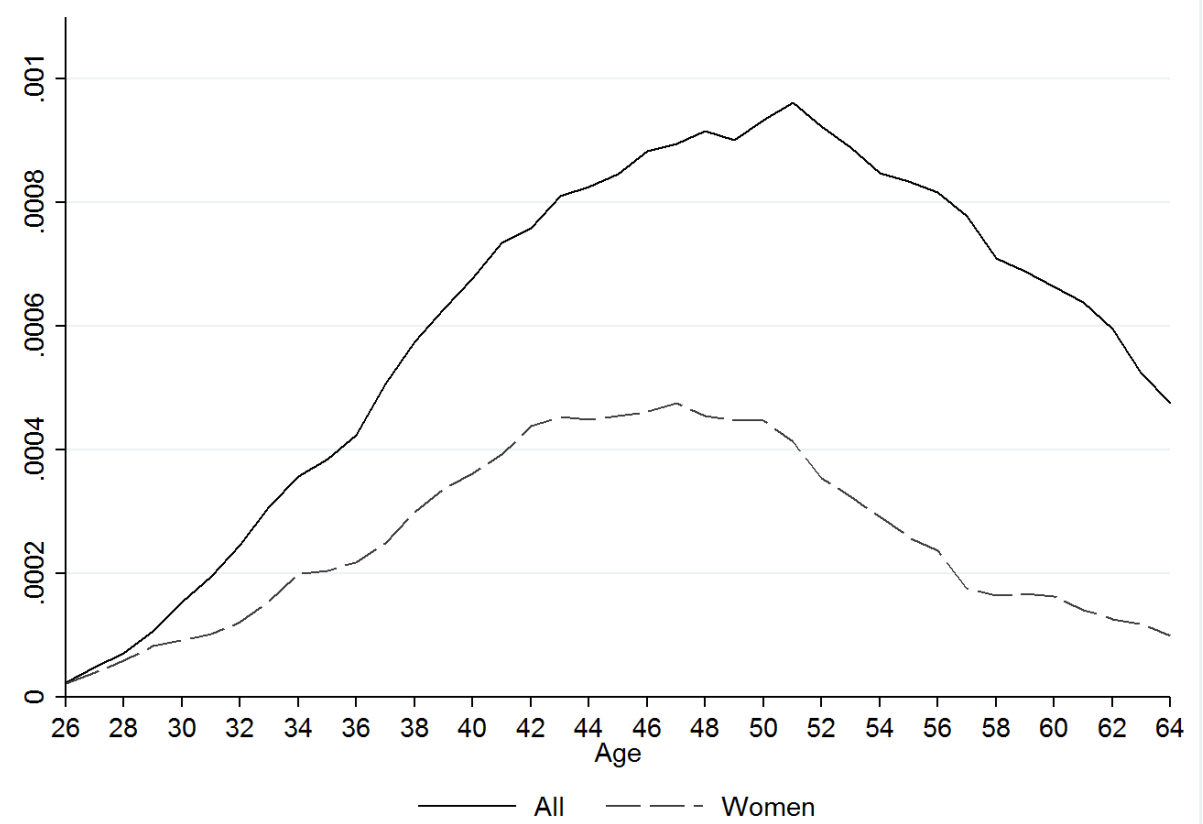

Note: The figure shows the share in the population of 26 to 64 year olds that are members of ASA boards (solid line) and the share of all females between 26 and 64 that are member of ASA boards (dashed line). 


\section{Appendix Figure 2: Change in Women's Probability of Becoming a Board Member 2004-2014 Cohort vs. 1998-2003 Cohort (as a Function of Baseline Percentile of the Board Human Capital Index)}

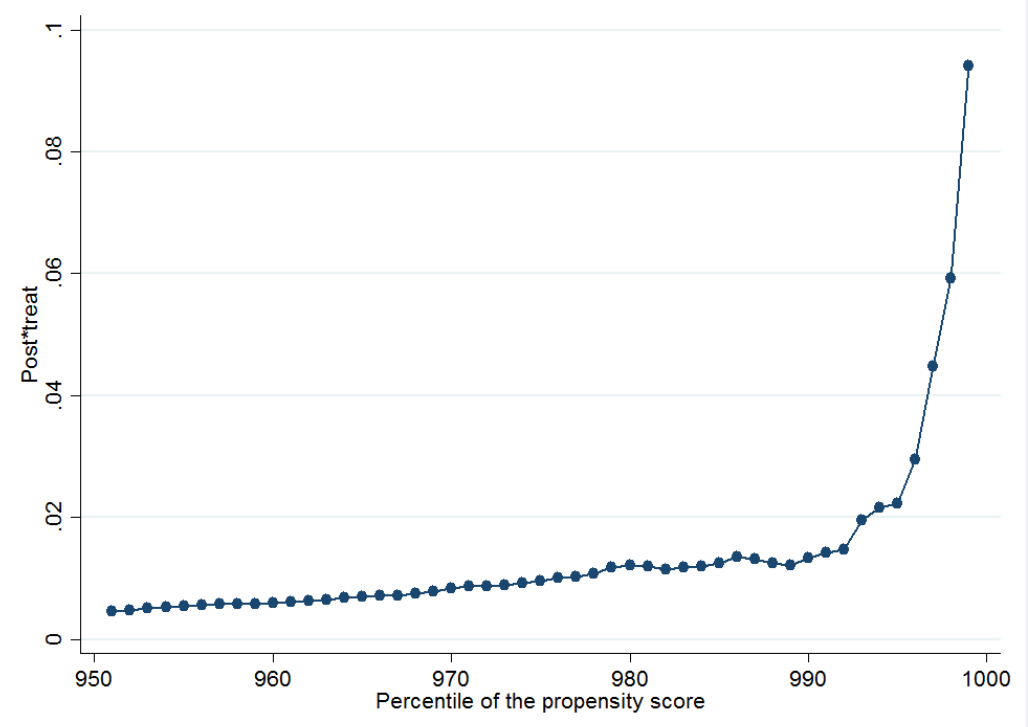

Note: Figure reports the coefficient of post*treat in regression where ASA=1 is the outcome, post $=1$ if the cohort is 2004 or 2008 and treat $=1$ for individual $i$ if i's predicted propensity of becoming a board member is above the $n$-th percentile of the propensity score distribution. We estimate this regression for females only letting the percentile vary. If there is a real cutoff at a given percentile, above which a person is always appointed to the board, then the coefficient should reach a maximum at that cutoff as shown in Appendix Figure 3. 


\section{Appendix Figure 3: Finding cutoff percentile}

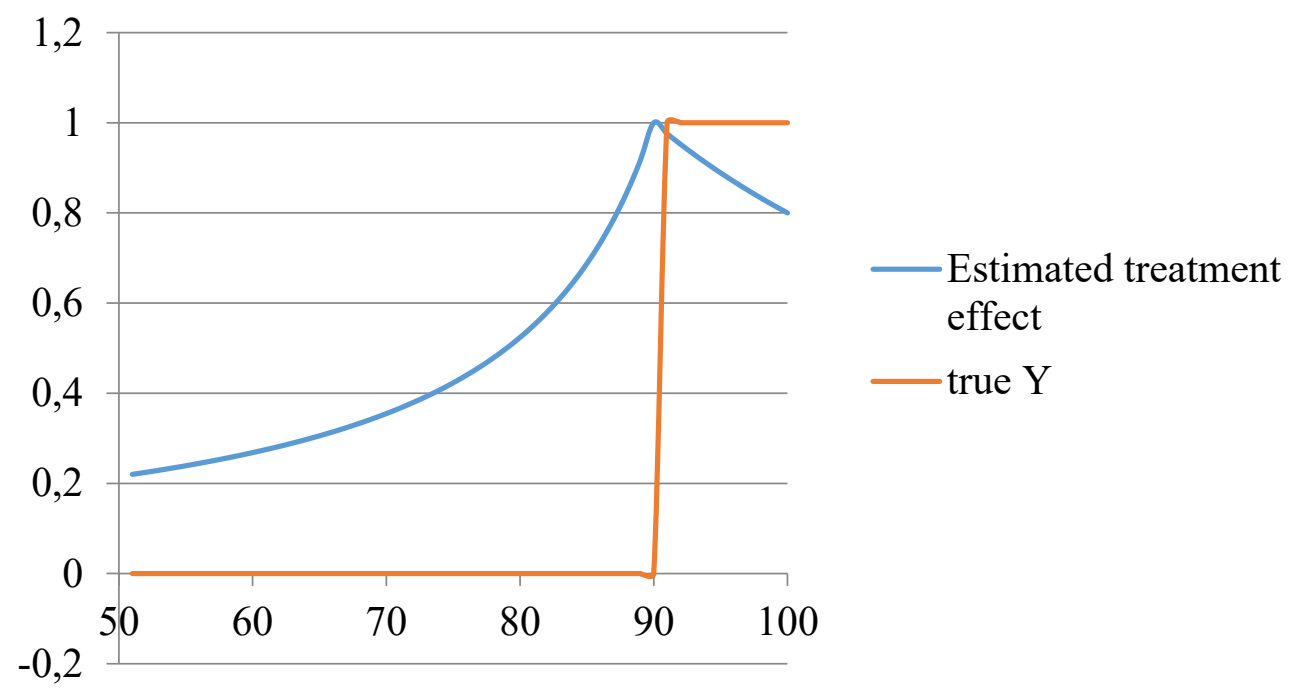

Note: This figure reports the results from simulated regressions. The value of Y changes from 0 to 1 at the 90th percentile of the running variable, so 90 is the real cutoff. The blue line report the coefficient of a regression of $\mathrm{Y}$ on a dummy for the running value being greater than percentile $\mathrm{x}$. For example, the value at the 50th percentile is the mean difference in $\mathrm{Y}$ for observations above the 50th percentile and observations below. Since we do not know what the real cutoff is, we run this regression for all percentiles. What the graph shows is that the coefficient reaches a max when the dummy is correctly defined at exactly the 90th percentile. 
Table 1a: Characteristics of Board Members

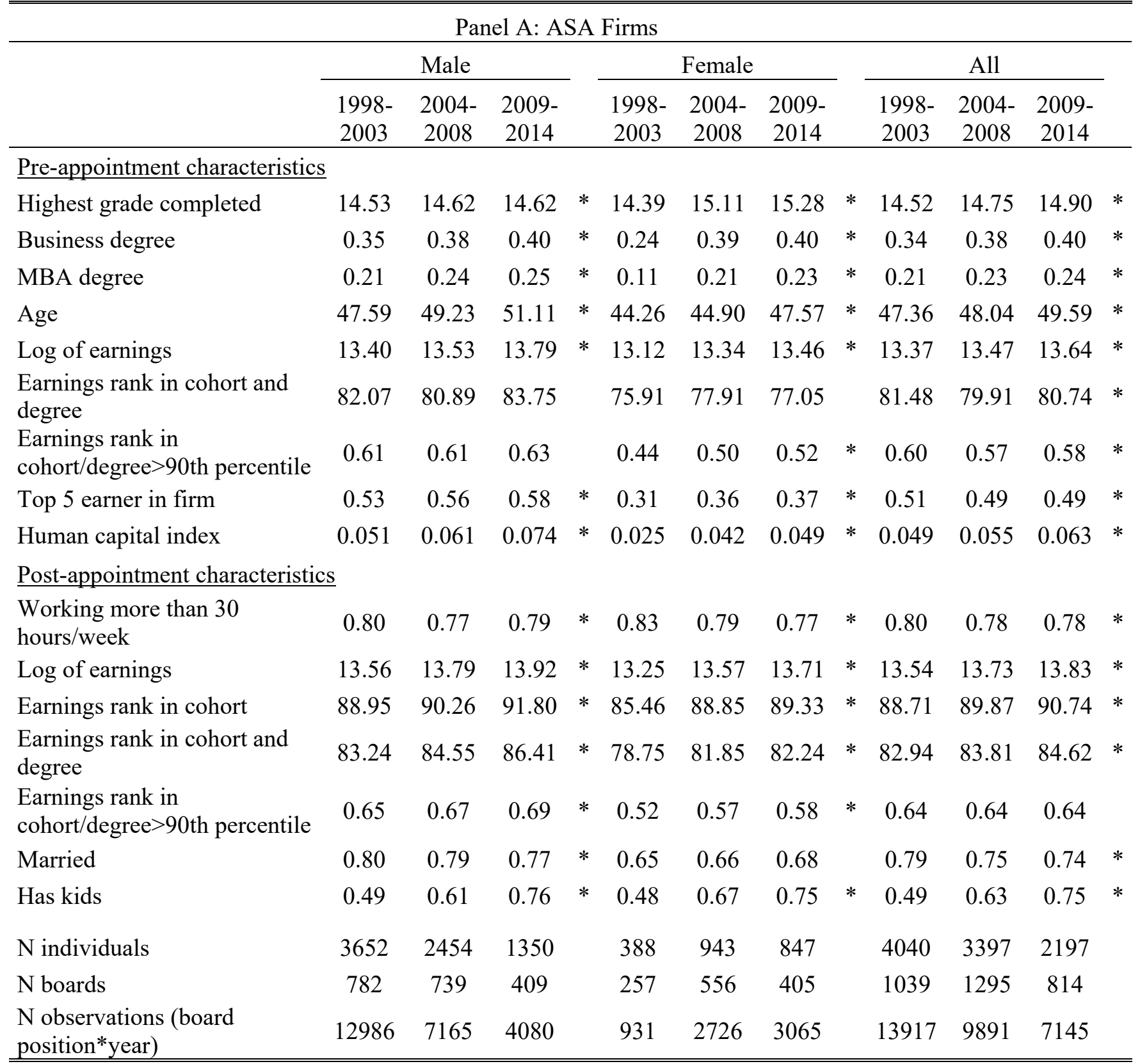

Note: The table report means characteristics for board members in all ASA firms in the three indicated periods. Stars in the table indicate that pre- (1998-2003) and post- (2004-2014) reform means are statistically different at the $5 \%$ level of significance. 
Table 1b: Characteristics of Board Members

\begin{tabular}{|c|c|c|c|c|c|c|c|c|c|c|c|c|}
\hline \multicolumn{13}{|c|}{ Panel B: ASA Firms in 2003} \\
\hline & \multicolumn{3}{|c|}{ Male } & \multicolumn{4}{|c|}{ Female } & \multicolumn{4}{|c|}{ All } & \\
\hline & $\begin{array}{l}1998- \\
2003\end{array}$ & $\begin{array}{l}2004- \\
2008 \\
\end{array}$ & $\begin{array}{c}2009- \\
2014\end{array}$ & & $\begin{array}{l}1998- \\
2003 \\
\end{array}$ & $\begin{array}{c}2004- \\
2008 \\
\end{array}$ & $\begin{array}{l}2009- \\
2014\end{array}$ & & $\begin{array}{l}1998- \\
2003\end{array}$ & $\begin{array}{c}2004- \\
2008 \\
\end{array}$ & $\begin{array}{l}2009- \\
2014 \\
\end{array}$ & \\
\hline \multicolumn{13}{|c|}{ Pre-appointment characteristics } \\
\hline $\begin{array}{l}\text { Highest grade } \\
\text { completed }\end{array}$ & 14.54 & 14.51 & 14.57 & & 14.43 & 14.86 & 15.03 & $*$ & 14.53 & 14.59 & 14.71 & $*$ \\
\hline Business degree & 0.34 & 0.38 & 0.42 & $*$ & 0.23 & 0.38 & 0.40 & $*$ & 0.34 & 0.38 & 0.42 & $*$ \\
\hline MBA degree & 0.21 & 0.23 & 0.24 & $*$ & 0.11 & 0.19 & 0.20 & $*$ & 0.20 & 0.22 & 0.23 & $*$ \\
\hline Age & 47.59 & 49.37 & 50.62 & $*$ & 44.31 & 45.45 & 47.72 & $*$ & 47.37 & 48.48 & 49.76 & $*$ \\
\hline Log of earnings & 13.30 & 13.37 & 13.53 & * & 12.95 & 13.19 & 13.24 & * & 13.25 & 13.30 & 13.42 & $*$ \\
\hline $\begin{array}{l}\text { Earnings rank in cohort } \\
\text { and degree }\end{array}$ & 81.81 & 80.13 & 82.12 & & 74.80 & 76.88 & 74.30 & & 80.72 & 78.93 & 79.04 & $*$ \\
\hline $\begin{array}{l}\text { Earnings rank in } \\
\text { cohort/degree }>90 \text { th } \\
\text { percentile }\end{array}$ & 0.56 & 0.53 & 0.54 & & 0.39 & 0.45 & 0.44 & $*$ & 0.53 & 0.50 & 0.50 & $*$ \\
\hline Top 5 earner in firm & 0.34 & 0.36 & 0.39 & $*$ & 0.17 & 0.25 & 0.24 & $*$ & 0.31 & 0.32 & 0.33 & \\
\hline Human capital index & 0.038 & 0.043 & 0.051 & $*$ & 0.017 & 0.035 & 0.035 & $*$ & 0.035 & 0.040 & 0.045 & $*$ \\
\hline \multicolumn{13}{|c|}{ Post-appoitment characteristics } \\
\hline $\begin{array}{l}\text { Working more than } 30 \\
\text { hours/week }\end{array}$ & 0.80 & 0.78 & 0.81 & $*$ & 0.84 & 0.80 & 0.80 & $*$ & 0.81 & 0.78 & 0.81 & $*$ \\
\hline Log of earnings & 13.57 & 13.74 & 13.85 & $*$ & 13.29 & 13.53 & 13.64 & $*$ & 13.55 & 13.69 & 13.78 & $*$ \\
\hline Earnings rank in cohort & 89.08 & 89.83 & 90.97 & $*$ & 86.35 & 88.16 & 86.97 & & 88.90 & 89.45 & 89.79 & $*$ \\
\hline $\begin{array}{l}\text { Earnings rank in cohort } \\
\text { and degree }\end{array}$ & 83.35 & 84.25 & 85.53 & * & 80.11 & 81.64 & 80.73 & & 83.13 & 83.66 & 84.11 & $*$ \\
\hline $\begin{array}{l}\text { Earnings rank in } \\
\text { cohort/degree }>90 \text { th } \\
\text { percentile }\end{array}$ & 0.65 & 0.66 & 0.66 & & 0.54 & 0.57 & 0.58 & * & 0.64 & 0.64 & 0.64 & \\
\hline Married & 0.80 & 0.79 & 0.77 & $*$ & 0.65 & 0.65 & 0.68 & & 0.79 & 0.76 & 0.74 & $*$ \\
\hline Has kids & 0.48 & 0.60 & 0.75 & $*$ & 0.47 & 0.64 & 0.71 & $*$ & 0.48 & 0.61 & 0.74 & $*$ \\
\hline $\mathrm{N}$ individuals & 3255 & 2126 & 1519 & & 342 & 708 & 638 & & 3597 & 2834 & 2157 & \\
\hline $\mathrm{N}$ boards & 588 & 473 & 346 & & 222 & 330 & 257 & & 810 & 803 & 603 & \\
\hline $\begin{array}{l}\mathrm{N} \text { observations (board } \\
\text { position*year) }\end{array}$ & 11986 & 6758 & 5184 & & 861 & 2000 & 2185 & & 12847 & 8758 & 7369 & \\
\hline
\end{tabular}

Note: The table report means characteristics for board members in all ASA firms that were ASA in 2003 (intent-to-treat sample) in the three indicated periods. Stars in the table indicate that pre- (1998-2003) and post- (2004-2014) reform means are statistically different at the 5\% level of significance. 
Table 2: Gender Gaps in Earnings among Board Members. 1998-2014

\begin{tabular}{|c|c|c|c|c|c|c|}
\hline & \multicolumn{3}{|c|}{ No Board FE } & \multicolumn{3}{|c|}{ Board FE } \\
\hline & $(1)$ & $(2)$ & (3) & $(4)$ & (5) & (6) \\
\hline $\begin{array}{l}\text { Dependent variable: } \\
\text { Log(earnings) }\end{array}$ & $\begin{array}{l}\text { Pre-reform } \\
1998-2003 \\
\end{array}$ & $\begin{array}{c}\begin{array}{c}\text { During } \\
\text { reform } \\
2004-2008\end{array} \\
\end{array}$ & $\begin{array}{c}\text { Post } \\
\text { reform } \\
2009-2014 \\
\end{array}$ & $\begin{array}{l}\text { Pre-reform } \\
1998-2003 \\
\end{array}$ & $\begin{array}{c}\begin{array}{c}\text { During } \\
\text { reform } \\
2004-2008\end{array} \\
\end{array}$ & $\begin{array}{c}\text { Post } \\
\text { reform } \\
2009-2014\end{array}$ \\
\hline \multicolumn{7}{|l|}{ Panel A: ASA Firms } \\
\hline Female & $\begin{array}{c}-0.263 * * * \\
{[0.062]}\end{array}$ & $\begin{array}{c}-0.306^{* * *} \\
{[0.045]}\end{array}$ & $\begin{array}{c}-0.247 * * * \\
{[0.048]}\end{array}$ & $\begin{array}{c}-0.364 * * * \\
{[0.054]}\end{array}$ & $\begin{array}{c}-0.353 * * * \\
{[0.040]}\end{array}$ & $\begin{array}{c}-0.237 * * * \\
{[0.039]}\end{array}$ \\
\hline Male mean & 13.63 & 13.95 & 14.18 & & & \\
\hline Female mean & 13.32 & 13.74 & 13.98 & & & \\
\hline$N$ females *board years & 922 & 2710 & 3038 & & & \\
\hline $\mathrm{N}$ & 13238 & 9437 & 6754 & 13238 & 9437 & 6754 \\
\hline $\mathrm{N}$ boards & 782 & 739 & 422 & & & \\
\hline \multicolumn{7}{|c|}{ Panel B: ASA Firms in 2003} \\
\hline Female & $\begin{array}{c}-0.231 * * * \\
{[0.066]}\end{array}$ & $\begin{array}{c}-0.266^{* * *} \\
{[0.048]}\end{array}$ & $\begin{array}{c}-0.250 * * * \\
{[0.053]}\end{array}$ & $\begin{array}{c}-0.350 * * * \\
{[0.057]}\end{array}$ & $\begin{array}{c}-0.338 * * * \\
{[0.044]}\end{array}$ & $\begin{array}{c}-0.255^{* * *} \\
{[0.042]}\end{array}$ \\
\hline Male mean & 13.63 & 13.9 & 14.11 & & & \\
\hline Female mean & 13.36 & 13.7 & 13.9 & & & \\
\hline$N$ females $*$ board years & 854 & 1986 & 2158 & & & \\
\hline $\mathrm{N}$ & 12210 & 8395 & 6973 & 12210 & 8395 & 6973 \\
\hline $\mathrm{N}$ boards & 588 & 473 & 348 & & & \\
\hline
\end{tabular}

Note: Sample includes all individuals observed serving in ASA boards (panel A) or serving in boards of firms that were ASA in 2003 (panel B). Standard errors clustered at the individual level. Regression includes controls for age, age squared, experience, experience squared, and year dummies.

$* * * \mathrm{p}<0.01 . * * \mathrm{p}<0.05 . * \mathrm{p}<0.1$. 
Table 3: Effect of Being a Board Member on Labor Market Outcomes

\begin{tabular}{|c|c|c|c|c|}
\hline \multicolumn{5}{|c|}{ Sample: ASA Firms } \\
\hline & & $\begin{array}{l}\text { Pre-reform } \\
1998-2003 \\
\end{array}$ & $\begin{array}{c}\text { During reform } \\
2004-2008\end{array}$ & $\begin{array}{c}\text { Post reform } \\
2009-2014\end{array}$ \\
\hline \multicolumn{5}{|l|}{ Dependent variable: } \\
\hline \multirow[t]{2}{*}{ Log of annual earnings } & Women & $\begin{array}{c}0.103 * * * \\
{[0.023]}\end{array}$ & $\begin{array}{c}0.0686^{* * *} \\
{[0.022]}\end{array}$ & $\begin{array}{c}0.0798 * * * \\
{[0.022]}\end{array}$ \\
\hline & Men & $\begin{array}{c}0.0498 * * * \\
{[0.013]}\end{array}$ & $\begin{array}{c}0.0723^{* * *} \\
{[0.018]}\end{array}$ & $\begin{array}{c}0.0862 * * * \\
{[0.020]}\end{array}$ \\
\hline \multirow[t]{2}{*}{ Top 5 earner in firm $(Y=1)$} & Women & $\begin{array}{c}0.0434 * * \\
{[0.018]}\end{array}$ & $\begin{array}{c}0.0355^{* * *} \\
{[0.013]}\end{array}$ & $\begin{array}{c}0.0479 * * * \\
{[0.016]}\end{array}$ \\
\hline & Men & $\begin{array}{c}0.0277 * * * \\
{[0.008]}\end{array}$ & $\begin{array}{c}0.0283 * * * \\
{[0.009]}\end{array}$ & $\begin{array}{l}0.0202 * \\
{[0.011]}\end{array}$ \\
\hline Observations for women & & 8307 & 7081 & 8092 \\
\hline Observations for men & & 28729 & 22547 & 22859 \\
\hline
\end{tabular}

Note: Sample include all individuals observed being on an ASA board between 1998 and 2014. Each coefficient comes from a separate regression by gender and time period. Specification includes age, age squared, experience, experience squared, year dummies and individual fixed effects. Standard errors are clustered at the individual level.

$* * * \mathrm{p}<0.01, * * \mathrm{p}<0.05, * \mathrm{p}<0.1$. 
Table 4: Effect of Board Gender Quota on Female Outcomes in ASA Business Groups: Instrumental Variable Regressions

\begin{tabular}{|c|c|c|c|c|c|c|c|c|c|c|c|c|c|c|}
\hline \multirow[t]{3}{*}{ Dependent variable: } & \multicolumn{10}{|c|}{$\begin{array}{l}\text { Panel A: Treated ASA Business Groups } \\
\text { Share of female employees with earning above the .... } \\
\text { in the earnings distribution: }\end{array}$} & \multirow{2}{*}{\multicolumn{2}{|c|}{$\begin{array}{l}\text { Top earner is a } \\
\text { woman? }(Y=1)\end{array}$}} & & \\
\hline & \multirow{2}{*}{$\begin{array}{l}\text { women } \\
\text { (1) }\end{array}$} & \multirow{2}{*}{$\begin{array}{r}\text { women } \\
\text { with } M B A \\
(2)\end{array}$} & \multirow{2}{*}{$\begin{array}{r}\text { women } \\
\text { with kids } \\
(3)\end{array}$} & \multirow{2}{*}{$\begin{array}{r}\begin{array}{r}\text { women } \\
\text { working } \\
\text { part-time }\end{array} \\
(4)\end{array}$} & \multicolumn{2}{|c|}{ 75th percentile } & \multicolumn{2}{|c|}{ 90th percentile } & \multicolumn{2}{|c|}{ 95th percentile } & & & \multicolumn{2}{|c|}{$\begin{array}{l}\text { Number of } \\
\text { women among } \\
\text { top } 5 \text { earners }\end{array}$} \\
\hline & & & & & $(5)$ & (6) & (7) & (8) & (9) & $(10)$ & $(11)$ & $(12)$ & $(13)$ & (14) \\
\hline \multirow[t]{2}{*}{$\begin{array}{l}\text { Percent women on board in } \\
\text { year } t\end{array}$} & -0.0122 & $-0.0199 *$ & -0.0289 & 0.0442 & -0.0751 & -0.0379 & -0.0268 & -0.0104 & 0.0004 & 0.0183 & 0.141 & 0.0838 & -0.411 & -0.365 \\
\hline & {$[0.071]$} & {$[0.012]$} & {$[0.055]$} & {$[0.059]$} & {$[0.046]$} & {$[0.026]$} & {$[0.030]$} & {$[0.016]$} & {$[0.018]$} & {$[0.013]$} & {$[0.201]$} & {$[0.195]$} & {$[0.550]$} & [0.458] \\
\hline Time-varying group controls & No & No & No & No & No & Yes & No & Yes & No & Yes & No & Yes & No & Yes \\
\hline Observations & 1656 & 1656 & 1656 & 1656 & 1514 & 1514 & 1379 & 1379 & 1193 & 1193 & 1656 & 1656 & 1656 & 1656 \\
\hline R-squared & 0.927 & 0.793 & 0.913 & 0.797 & 0.868 & 0.897 & 0.746 & 0.800 & 0.635 & 0.721 & 0.464 & 0.496 & 0.627 & 0.708 \\
\hline
\end{tabular}

Panel B: Intent-to-Treat ASA Business Groups

\begin{tabular}{|c|c|c|c|c|c|c|c|c|c|c|c|c|c|c|}
\hline \multirow[t]{2}{*}{ Dependent variable: } & \multicolumn{4}{|c|}{ Share of employees that are: } & \multicolumn{6}{|c|}{$\begin{array}{c}\text { Share of female employees with earning above the .... } \\
\text { in the earnings distribution: }\end{array}$} & \multirow{2}{*}{\multicolumn{2}{|c|}{$\begin{array}{l}\text { Top earner is a } \\
\text { woman? }(Y=1)\end{array}$}} & \multirow{2}{*}{\multicolumn{2}{|c|}{$\begin{array}{l}\text { Number of } \\
\text { women among } \\
\text { top } 5 \text { earners }\end{array}$}} \\
\hline & women & $\begin{array}{r}\text { women } \\
\text { with } M B A\end{array}$ & $\begin{array}{r}\text { women } \\
\text { with kids }\end{array}$ & $\begin{array}{r}\text { women } \\
\text { working } \\
\text { part-time }\end{array}$ & \multicolumn{2}{|c|}{ 75th percentile } & \multicolumn{2}{|c|}{ 90th percentile } & \multicolumn{2}{|c|}{ 95th percentile } & & & & \\
\hline year $\mathrm{t}$ & $\begin{array}{l}-0.115^{*} \\
{[0.062]}\end{array}$ & $\begin{array}{l}-0.0179 \\
{[0.013]}\end{array}$ & $\begin{array}{l}-0.110^{*} \\
{[0.061]}\end{array}$ & $\begin{array}{c}0.00589 \\
{[0.047]}\end{array}$ & $\begin{array}{l}-0.0828 \\
{[0.051]}\end{array}$ & $\begin{array}{l}-0.0268 \\
{[0.044]}\end{array}$ & $\begin{array}{l}-0.0355 \\
{[0.034]}\end{array}$ & $\begin{array}{c}0.0011 \\
{[0.028]}\end{array}$ & $\begin{array}{l}-0.0079 \\
{[0.019]}\end{array}$ & $\begin{array}{l}-0.0010 \\
{[0.011]}\end{array}$ & $\begin{array}{l}0.0015 \\
{[0.232]}\end{array}$ & $\begin{array}{l}-0.0220 \\
{[0.235]}\end{array}$ & $\begin{array}{l}-0.218 \\
{[0.564]}\end{array}$ & $\begin{array}{l}-0.090 \\
{[0.488]}\end{array}$ \\
\hline Time-varying group controls & No & No & No & No & No & Yes & No & Yes & No & Yes & No & Yes & No & Yes \\
\hline Observations & 2688 & 2688 & 2688 & 2688 & 2394 & 2394 & 2147 & 2147 & 1816 & 1816 & 2688 & 2688 & 2688 & 2688 \\
\hline R-squared & 0.937 & 0.510 & 0.881 & 0.916 & 0.746 & 0.790 & 0.622 & 0.698 & 0.621 & 0.680 & 0.385 & 0.420 & 0.562 & 0.636 \\
\hline
\end{tabular}

Note: Sample in Panel A includes business groups that are ASA in the current year and were ASA in 2003 (treated sample); sample in Panel B includes all business groups that were ASA in 2003 (intent-to-treat sample). Panels A and B cover the time period 2003 to 2014. "Percent women on board in year t" is the percentage of women on the board of the parent company in a given year; it is instrumented for by the percentage of women on the board in 2003 interacted with year dummies. Appendix Table A7 reports the first-stage regressions. All regressions include parent company fixed effects, year fixed effects and control for the share of employees in each of 20 different industry categories in the current year. Timevarying group controls include: employee average age; share of employees with: lower secondary education, post-secondary education (no college), undergraduate education, graduate education, post-graduate education; share of employees that are women with: lower secondary education, post-secondary education (no college), undergraduate education, graduate education, post-graduate education; share of employees with MBAs; share of employees that are married; share of employees with kids; share of employees that are women with MBAs; share of employees that are married women; share of employees that are women with kids. Observations in all columns except the last 4 are weighted by total employment in the business group in 2003. Standard errors are clustered at the parent company level. $* * * \mathrm{p}<0.01,{ }^{* *} \mathrm{p}<0.05,{ }^{*} \mathrm{p}<0.1$. 
Table 5: Effect of Board Gender Quota on Female Outcomes in ASA Firms. Instrumental Variable Regressions

\begin{tabular}{|c|c|c|c|c|c|c|c|c|c|c|c|c|c|c|}
\hline \multirow{4}{*}{ Dependent variable: } & \multicolumn{14}{|c|}{ Panel A: Treated ASA Firms } \\
\hline & \multicolumn{4}{|c|}{ Share of employees that are: } & \multicolumn{6}{|c|}{$\begin{array}{c}\text { Share of female employees with earning above the ... } \\
\text { in the earnings distribution: }\end{array}$} & \multirow{2}{*}{\multicolumn{2}{|c|}{$\begin{array}{l}\text { Top earner is a } \\
\text { woman? }(Y=1)\end{array}$}} & \multirow{2}{*}{\multicolumn{2}{|c|}{$\begin{array}{c}\text { Number of } \\
\text { women among } \\
\text { top } 5 \text { earners }\end{array}$}} \\
\hline & \multirow{2}{*}{$\frac{\text { women }}{(1)}$} & \multirow{2}{*}{$\begin{array}{r}\text { women } \\
\text { with } M B A \\
(2)\end{array}$} & \multirow{2}{*}{$\begin{array}{r}\begin{array}{r}\text { women } \\
\text { with kids }\end{array} \\
(3)\end{array}$} & \multirow{2}{*}{$\begin{array}{r}\begin{array}{r}\text { women } \\
\text { working } \\
\text { part-time }\end{array} \\
(4)\end{array}$} & \multicolumn{2}{|c|}{ 75th percentile } & \multicolumn{2}{|c|}{ 90th percentile } & \multicolumn{2}{|c|}{ 95th percentile } & & & & \\
\hline & & & & & $(5)$ & (6) & $(7)$ & $(8)$ & $(9)$ & $(10)$ & (11) & $(12)$ & $(13)$ & $(14)$ \\
\hline $\begin{array}{l}\text { Percent women on board in } \\
\text { year } t\end{array}$ & $\begin{array}{l}-0.0163 \\
{[0.066]}\end{array}$ & $\begin{array}{l}0.0053 \\
{[0.015]}\end{array}$ & $\begin{array}{l}0.048^{* *} \\
{[0.022]}\end{array}$ & $\begin{array}{l}-0.0366 \\
{[0.041]}\end{array}$ & $\begin{array}{c}-0.0903 * * * \\
{[0.031]}\end{array}$ & $\begin{array}{l}-0.0706^{* * *} \\
{[0.022]}\end{array}$ & $\begin{array}{c}-0.0329^{*} \\
{[0.019]}\end{array}$ & $\begin{array}{l}-0.0293 \\
{[0.018]}\end{array}$ & $\begin{array}{l}-0.0204 \\
{[0.013]}\end{array}$ & $\begin{array}{l}-0.0102 \\
{[0.012]}\end{array}$ & $\begin{array}{l}-0.0314 \\
{[0.177]}\end{array}$ & $\begin{array}{l}-0.0715 \\
{[0.165]}\end{array}$ & $\begin{array}{l}-0.437 \\
{[0.533]}\end{array}$ & $\begin{array}{l}-0.368 \\
{[0.424]}\end{array}$ \\
\hline Time-varying firm controls & No & No & No & No & No & Yes & No & Yes & No & Yes & No & Yes & No & Yes \\
\hline Observations & 2147 & 2145 & 2147 & 2147 & 1773 & 1773 & 1426 & 1426 & 1028 & 1028 & 2147 & 2145 & 2147 & 2145 \\
\hline R-squared & 0.796 & 0.660 & 0.766 & 0.422 & 0.521 & 0.675 & 0.443 & 0.596 & 0.504 & 0.629 & 0.445 & 0.493 & 0.600 & 0.701 \\
\hline
\end{tabular}

Panel B: Intent-to-Treat ASA Firms

\begin{tabular}{|c|c|c|c|c|c|c|c|c|c|c|c|c|c|c|}
\hline \multirow[t]{2}{*}{ Dependent variable: } & \multicolumn{4}{|c|}{ Share of employees that are: } & \multicolumn{6}{|c|}{$\begin{array}{c}\text { Share of female employees with earning above the .... } \\
\text { in the earnings distribution: }\end{array}$} & \multirow{2}{*}{\multicolumn{2}{|c|}{$\begin{array}{l}\text { Top earner is a } \\
\text { woman? }(Y=1)\end{array}$}} & \multirow{2}{*}{\multicolumn{2}{|c|}{$\begin{array}{l}\text { Number of } \\
\text { women among } \\
\text { top } 5 \text { earners }\end{array}$}} \\
\hline & women & $\begin{array}{l}\text { women } \\
\text { with } M B A\end{array}$ & $\begin{array}{l}\text { women } \\
\text { with kids }\end{array}$ & $\begin{array}{c}\text { women } \\
\text { working } \\
\text { part-time }\end{array}$ & \multicolumn{2}{|c|}{ 75th percentile } & \multicolumn{2}{|c|}{ 90th percentile } & \multicolumn{2}{|c|}{ 95th percentile } & & & & \\
\hline $\begin{array}{l}\text { Percent women on board in } \\
\text { year } t\end{array}$ & $\begin{array}{l}-0.0479 \\
{[0.051]}\end{array}$ & $\begin{array}{l}-0.0139 \\
{[0.025]}\end{array}$ & $\begin{array}{c}0,0004 \\
{[0.033]}\end{array}$ & $\begin{array}{l}-0.0234 \\
{[0.045]}\end{array}$ & $\begin{array}{c}-0.0871 * * * \\
{[0.033]}\end{array}$ & $\begin{array}{c}-0.0754 * * * \\
{[0.027]}\end{array}$ & $\begin{array}{c}-0.0318 * \\
{[0.019]}\end{array}$ & $\begin{array}{l}-0.0231 \\
{[0.020]}\end{array}$ & $\begin{array}{l}-0.0121 \\
{[0.012]}\end{array}$ & $\begin{array}{l}-0,0012 \\
{[0.013]}\end{array}$ & $\begin{array}{l}-0.0573 \\
{[0.175]}\end{array}$ & $\begin{array}{l}-0.0263 \\
{[0.164]}\end{array}$ & $\begin{array}{l}-0.321 \\
{[0.749]}\end{array}$ & $\begin{array}{l}-0.0056 \\
{[0.629]}\end{array}$ \\
\hline Time-varying firm controls & No & No & No & No & No & Yes & No & Yes & No & Yes & No & Yes & No & Yes \\
\hline Observations & 3191 & 3189 & 3191 & 3191 & 2590 & 2590 & 2096 & 2096 & 1585 & 1585 & 3191 & 3189 & 3191 & 3189 \\
\hline R-squared & 0.792 & 0.465 & 0.729 & 0.471 & 0.530 & 0.649 & 0.449 & 0.575 & 0.485 & 0.575 & 0.404 & 0.453 & 0.535 & 0.646 \\
\hline
\end{tabular}

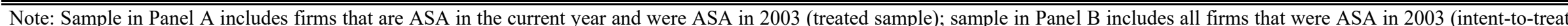

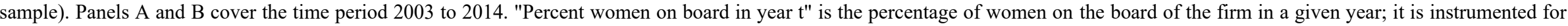

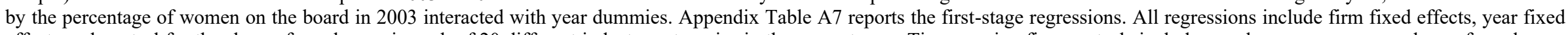

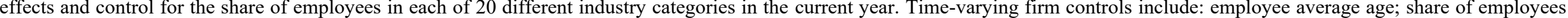

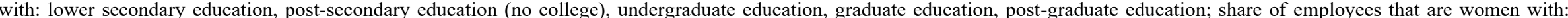

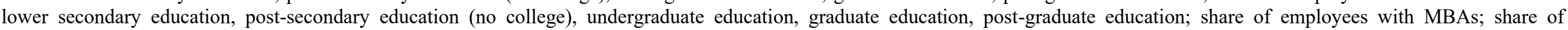

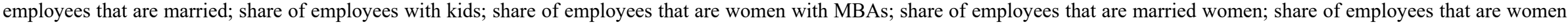

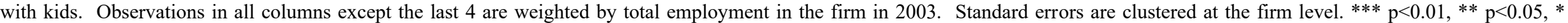
$\mathrm{p}<0.1$. 
Table 6a: Effect of Board Gender Quota on Female Outcomes in ASA Business Groups and Firms. Reduced Form Regressions

\section{Panel A: Intent-to-Treat ASA Business Groups}

\begin{tabular}{|c|c|c|c|c|c|c|c|c|c|c|c|c|c|c|}
\hline \multirow{2}{*}{$\begin{array}{l}\text { Percentage of women on the board } \\
\text { in } 2003^{*}\end{array}$} & \multicolumn{4}{|c|}{ Share of employees that are: } & \multicolumn{6}{|c|}{$\begin{array}{c}\text { Share of female employees with earning above the .... } \\
\text { in the earnings distribution: }\end{array}$} & \multirow{2}{*}{\multicolumn{2}{|c|}{$\begin{array}{l}\text { Women is top } \\
\text { earner? }(Y=1)\end{array}$}} & \multirow{2}{*}{\multicolumn{2}{|c|}{$\begin{array}{c}\text { Number of } \\
\text { women among } \\
\text { top } 5 \text { earners }\end{array}$}} \\
\hline & women & $\begin{array}{r}\text { women } \\
\text { with } \\
\text { MBA } \\
\end{array}$ & $\begin{array}{r}\text { women } \\
\text { with kids }\end{array}$ & $\begin{array}{r}\text { women } \\
\text { working } \\
\text { part- } \\
\text { time } \\
\end{array}$ & \multicolumn{2}{|c|}{ 75th percentile } & \multicolumn{2}{|c|}{ 90th percentile } & \multicolumn{2}{|c|}{ 95th percentile } & & & & \\
\hline $1999-2003$ & $\begin{array}{c}0.0160 \\
{[0.016]}\end{array}$ & $\begin{array}{c}0.00271 \\
{[0.003]}\end{array}$ & $\begin{array}{c}0.0256 \\
{[0.018]}\end{array}$ & $\begin{array}{c}0.0007 \\
{[0.011]}\end{array}$ & $\begin{array}{l}-0.0141 \\
{[0.019]}\end{array}$ & $\begin{array}{l}-0.0207 \\
{[0.018]}\end{array}$ & $\begin{array}{l}-0.0017 \\
{[0.013]}\end{array}$ & $\begin{array}{l}-0.0077 \\
{[0.012]}\end{array}$ & $\begin{array}{l}0.0017 \\
{[0.004]}\end{array}$ & $\begin{array}{c}0.0033 \\
{[0.004]}\end{array}$ & $\begin{array}{l}0.0938 \\
{[0.078]}\end{array}$ & $\begin{array}{l}0.0601 \\
{[0.073]}\end{array}$ & $\begin{array}{c}0.353 \\
{[0.312]}\end{array}$ & $\begin{array}{c}0.268 \\
{[0.302]}\end{array}$ \\
\hline 2004-2008 & $\begin{array}{c}0.0240 \\
{[0.030]}\end{array}$ & $\begin{array}{c}0.00556 \\
{[0.004]}\end{array}$ & $\begin{array}{c}0.0457 \\
{[0.034]}\end{array}$ & $\begin{array}{c}0.0083 \\
{[0.023]}\end{array}$ & $\begin{array}{l}0.0272 \\
{[0.033]}\end{array}$ & $\begin{array}{l}0.0128 \\
{[0.025]}\end{array}$ & $\begin{array}{c}0.0199 \\
{[0.024]}\end{array}$ & $\begin{array}{c}0.0056 \\
{[0.019]}\end{array}$ & $\begin{array}{c}0.0092 \\
{[0.012]}\end{array}$ & $\begin{array}{l}0.0108 \\
{[0.008]}\end{array}$ & $\begin{array}{c}0.114 \\
{[0.076]}\end{array}$ & $\begin{array}{l}0.0682 \\
{[0.069]}\end{array}$ & $\begin{array}{c}0.432 \\
{[0.381]}\end{array}$ & $\begin{array}{c}0.276 \\
{[0.357]}\end{array}$ \\
\hline $2009-2014$ & $\begin{array}{c}0.0738 \\
{[0.049]}\end{array}$ & $\begin{array}{c}0.0114 \\
{[0.010]}\end{array}$ & $\begin{array}{l}0.0816^{*} \\
{[0.048]}\end{array}$ & $\begin{array}{l}-0.0161 \\
{[0.032]}\end{array}$ & $\begin{array}{c}0.0446 \\
{[0.048]}\end{array}$ & $\begin{array}{l}0.0128 \\
{[0.037]}\end{array}$ & $\begin{array}{c}0.0228 \\
{[0.031]}\end{array}$ & $\begin{array}{l}-0.0016 \\
{[0.024]}\end{array}$ & $\begin{array}{c}0.0094 \\
{[0.015]}\end{array}$ & $\begin{array}{l}0.0096 \\
{[0.010]}\end{array}$ & $\begin{array}{l}0.0373 \\
{[0.104]}\end{array}$ & $\begin{array}{l}0.0299 \\
{[0.101]}\end{array}$ & $\begin{array}{c}0.319 \\
{[0.379]}\end{array}$ & $\begin{array}{c}0.319 \\
{[0.357]}\end{array}$ \\
\hline $\begin{array}{l}\text { F-test: Pct women on board in } \\
2003 * 1999-2003=\text { Pct women on } \\
\text { the board } 2003 * 2009-2014 \text { (p- } \\
\text { value) }\end{array}$ & 0.16 & 0.33 & 0.13 & 0.57 & 0.15 & 0.30 & 0.31 & 0.73 & 0.58 & 0.49 & 0.59 & 0.78 & 0.90 & 0.84 \\
\hline Time-varying firm controls & No & No & No & No & No & Yes & No & Yes & No & Yes & No & Yes & No & Yes \\
\hline Observations & 4142 & 4141 & 4142 & 4142 & 3651 & 3651 & 3272 & 3272 & 2788 & 2788 & 4142 & 4141 & 4142 & 4141 \\
\hline R-squared & 0.938 & 0.506 & 0.854 & 0.902 & 0.748 & 0.779 & 0.593 & 0.654 & 0.579 & 0.626 & 0.298 & 0.346 & 0.495 & 0.583 \\
\hline
\end{tabular}

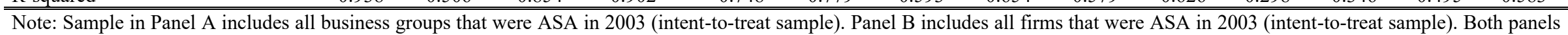

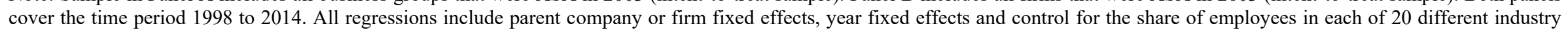

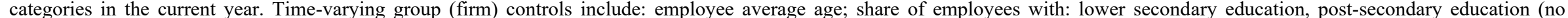

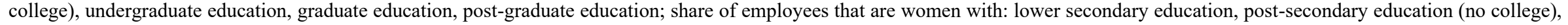

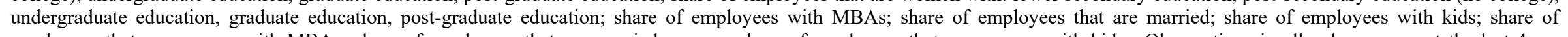

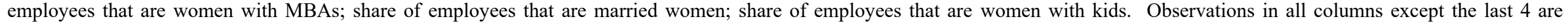

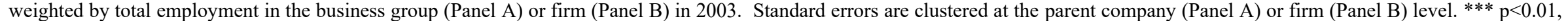
** $\mathrm{p}<0.05,{ }^{*} \mathrm{p}<0.1$. 
Table 6b: Effect of Board Gender Quota on Female Outcomes in ASA Business Groups and Firms. Reduced Form Regressions

\section{Panel B Intent-to-Treat ASA Firms}

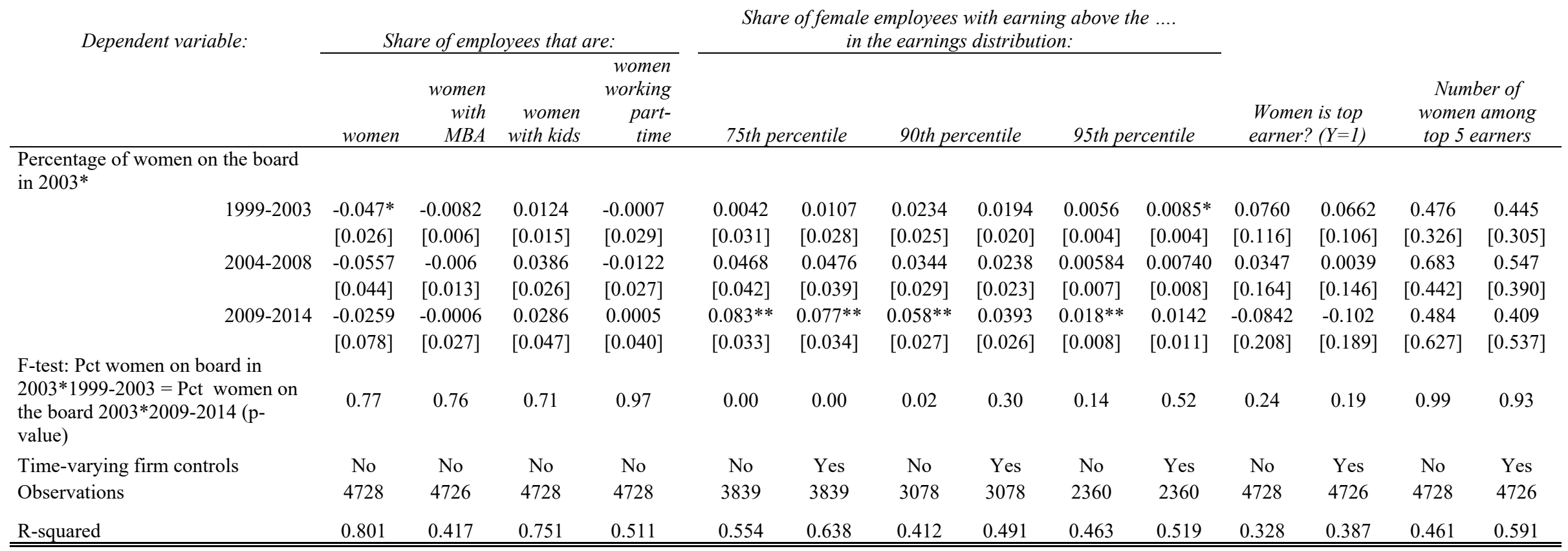

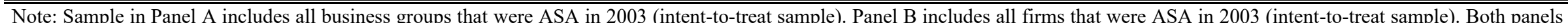

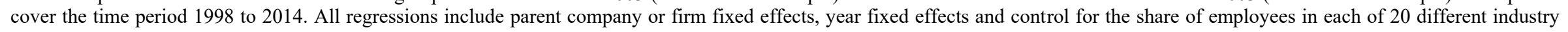

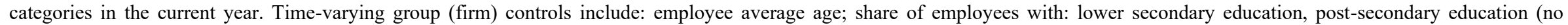

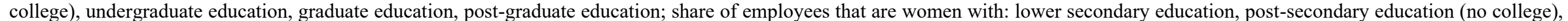

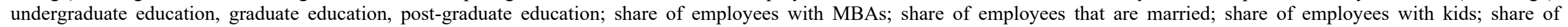

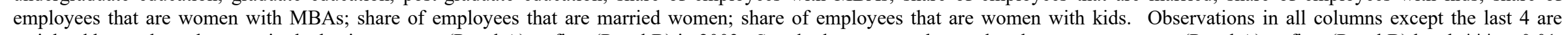

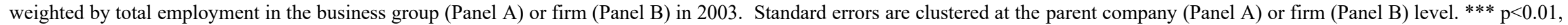
$* * \mathrm{p}<0.05, * \mathrm{p}<0.1$. 
Table 7: Gender Gaps in Earnings among Top Business Earners, Ages 35-55

\begin{tabular}{|c|c|c|c|c|c|c|}
\hline \multicolumn{7}{|c|}{ Dependent variable: Log(annual earnings) } \\
\hline Sample: & \multicolumn{2}{|c|}{ Top Earners } & \multicolumn{2}{|c|}{$\begin{array}{c}\text { Dropping Board } \\
\text { Members }\end{array}$} & \multicolumn{2}{|c|}{ Counterfactuals } \\
\hline Affected group: & $\begin{array}{l}\text { Pscore } \\
>99.5 \\
\end{array}$ & $\begin{array}{c}\text { P98 \& } \\
\text { bus }\end{array}$ & $\begin{array}{l}\text { Pscore } \\
>99.5 \\
\end{array}$ & $\begin{array}{c}\text { P98 \& } \\
\text { bus }\end{array}$ & $\begin{array}{l}\text { Pscore } \\
90-99 \\
\end{array}$ & $\begin{array}{l}\text { Pscore } \\
99-99.5 \\
\end{array}$ \\
\hline Panel A: Basic Specification & & & & & & \\
\hline Female*(2009-2013) & $\begin{array}{l}0.0476 \\
{[0.042]}\end{array}$ & $\begin{array}{l}0.0784 \\
{[0.063]}\end{array}$ & $\begin{array}{l}0.0112 \\
{[0.042]}\end{array}$ & $\begin{array}{l}0.0111 \\
{[0.070]}\end{array}$ & $\begin{array}{c}0.0186^{* *} \\
{[0.008]}\end{array}$ & $\begin{array}{l}0.0154 \\
{[0.035]}\end{array}$ \\
\hline Female*(2004-2008) & $\begin{array}{c}-0.00045 \\
{[0.045]}\end{array}$ & $\begin{array}{l}0.0362 \\
{[0.067]}\end{array}$ & $\begin{array}{l}-0.0643 \\
{[0.046]}\end{array}$ & $\begin{array}{l}-0.047 \\
{[0.075]}\end{array}$ & $\begin{array}{l}0.0079 \\
{[0.039]}\end{array}$ & $\begin{array}{l}-0.0484 \\
{[0.041]}\end{array}$ \\
\hline Female*(1999-2003) & $\begin{array}{c}0.0562 \\
{[0.047]}\end{array}$ & $\begin{array}{c}0.065 \\
{[0.069]}\end{array}$ & $\begin{array}{c}0.0237 \\
{[0.051]}\end{array}$ & $\begin{array}{l}0.0516 \\
{[0.079]}\end{array}$ & $\begin{array}{c}0.0092 \\
{[0.009]}\end{array}$ & $\begin{array}{l}-0.0033 \\
{[0.048]}\end{array}$ \\
\hline Female baseline (1994-1998) & $\begin{array}{c}-0.130^{* * *} \\
{[0.039]}\end{array}$ & $\begin{array}{c}-0.157 * * * \\
{[0.060]}\end{array}$ & $\begin{array}{c}-0.136^{* * *} \\
{[0.040]}\end{array}$ & $\begin{array}{l}-0.129^{*} \\
{[0.067]}\end{array}$ & $\begin{array}{c}-0.0614 * * * \\
{[0.007]}\end{array}$ & $\begin{array}{l}-0.0522 \\
{[0.033]}\end{array}$ \\
\hline 1994-1998 Male mean & 13.6 & 13.59 & 13.54 & 13.53 & 13.11 & 13.29 \\
\hline 1994-1998 Female mean & 13.38 & 13.35 & 13.33 & 13.35 & 13.01 & 13.18 \\
\hline Observations & 109219 & 55245 & 95479 & 46623 & 871.010 & 74.027 \\
\hline Panel B: controlling for lagg & & & & & & \\
\hline Female*(2009-2013) & $\begin{array}{l}0.0265 \\
{[0.016]}\end{array}$ & $\begin{array}{l}0.0398 \\
{[0.028]}\end{array}$ & $\begin{array}{l}0.0125 \\
{[0.017]}\end{array}$ & $\begin{array}{l}0.0128 \\
{[0.031]}\end{array}$ & & \\
\hline Female*(2004-2008) & $\begin{array}{c}-0.00889 \\
{[0.018]}\end{array}$ & $\begin{array}{l}0.0122 \\
{[0.030]}\end{array}$ & $\begin{array}{c}-0.0349^{*} \\
{[0.020]}\end{array}$ & $\begin{array}{l}-0.0243 \\
{[0.034]}\end{array}$ & & \\
\hline Female*(1999-2003) & $\begin{array}{l}0.0244 \\
{[0.019]}\end{array}$ & $\begin{array}{c}0.0332 \\
{[0.030]}\end{array}$ & $\begin{array}{l}0.00539 \\
{[0.021]}\end{array}$ & $\begin{array}{l}0.0164 \\
{[0.034]}\end{array}$ & & \\
\hline Female baseline (1994-1998) & $\begin{array}{c}-0.0351^{* *} \\
{[0.015]}\end{array}$ & $\begin{array}{c}-0.0490^{*} \\
{[0.026]}\end{array}$ & $\begin{array}{c}-0.0369^{* *} \\
{[0.016]}\end{array}$ & $\begin{array}{l}-0.0384 \\
{[0.030]}\end{array}$ & & \\
\hline 1994-1998 Male mean & 13.6 & 13.59 & 13.54 & 13.53 & & \\
\hline 1994-1998 Female mean & 13.38 & 13.35 & 13.33 & 13.35 & & \\
\hline Observations & 108954 & 55136 & 95240 & 46526 & & \\
\hline
\end{tabular}

"Pscore $>99.5$ " corresponds to the sample of individuals who are predicted to have a propensity to be board members above the 99.5th percentile, based on their characteristics and estimates of how these characteristics affect board membership for men in the pre-period. The second sample selects individuals with earnings above the 98th percentile for three years in a row that also have a business degree. The regressions control for year dummies, age, age squared, potential experience dummies, and fixed individual characteristics (an indicator for whether the individual was working at the time of selection into his or her cohort, as well as marital status and presence of children at the time the individual was selected into his or her cohort). Standard errors [in brackets] clustered at the person level. ${ }^{* * *} \mathrm{p}<0.01,{ }^{* *} \mathrm{p}<0.05,{ }^{*} \mathrm{p}<0.1$. 
Table 8: Gender Gaps in Representation in C-Suite among Top Business Earners, Ages 35-55

\begin{tabular}{|c|c|c|c|c|c|c|}
\hline \multicolumn{7}{|c|}{ Dependent variable: Top 5 earner in firm and year $(Y=1)$} \\
\hline Sample: & \multicolumn{2}{|c|}{ Top Earners } & \multicolumn{2}{|c|}{$\begin{array}{c}\text { Dropping Board } \\
\text { Members }\end{array}$} & \multicolumn{2}{|c|}{ Counterfactuals } \\
\hline Affected group: & $\begin{array}{l}\text { Pscore } \\
>99.5\end{array}$ & $\begin{array}{c}\text { P98 \& } \\
\text { bus }\end{array}$ & $\begin{array}{l}\text { Pscore } \\
>99.5\end{array}$ & $\begin{array}{c}\text { P98 \& } \\
\text { bus }\end{array}$ & $\begin{array}{c}\text { Pscore } \\
90-99 \\
\end{array}$ & $\begin{array}{l}\text { Pscore } \\
99-99.5 \\
\end{array}$ \\
\hline Panel A: Basic Specification & & & & & & \\
\hline Female*(2009-2013) & $\begin{array}{l}-0.0129 \\
{[0.036]}\end{array}$ & $\begin{array}{l}0.0917^{*} \\
{[0.054]}\end{array}$ & $\begin{array}{l}-0.043 \\
{[0.038]}\end{array}$ & $\begin{array}{l}0.0357 \\
{[0.055]}\end{array}$ & $\begin{array}{l}0.0039 \\
{[0.009]}\end{array}$ & $\begin{array}{c}0.0650^{*} \\
{[0.039]}\end{array}$ \\
\hline Female*(2004-2008) & $\begin{array}{l}-0.0428 \\
{[0.037]}\end{array}$ & $\begin{array}{l}0.0565 \\
{[0.055]}\end{array}$ & $\begin{array}{c}-0.0703^{*} \\
{[0.039]}\end{array}$ & $\begin{array}{l}0.0081 \\
{[0.058]}\end{array}$ & $\begin{array}{l}0.0170^{*} \\
{[0.009]}\end{array}$ & $\begin{array}{c}0.0828 * * \\
{[0.041]}\end{array}$ \\
\hline Female*(1999-2003) & $\begin{array}{l}-0.0396 \\
{[0.038]}\end{array}$ & $\begin{array}{l}0.0845 \\
{[0.056]}\end{array}$ & $\begin{array}{l}-0.0472 \\
{[0.040]}\end{array}$ & $\begin{array}{l}0.0554 \\
{[0.059]}\end{array}$ & $\begin{array}{l}0.0019 \\
{[0.009]}\end{array}$ & $\begin{array}{c}0.0906^{* *} \\
{[0.042]}\end{array}$ \\
\hline Female baseline (1994-1998) & $\begin{array}{c}-0.0652^{*} \\
{[0.034]}\end{array}$ & $\begin{array}{c}-0.181 * * * \\
{[0.050]}\end{array}$ & $\begin{array}{c}-0.0653^{*} \\
{[0.035]}\end{array}$ & $\begin{array}{c}-0.167 * * * \\
{[0.051]}\end{array}$ & $\begin{array}{c}-0.0881 * * * \\
{[0.008]}\end{array}$ & $\begin{array}{c}-0.152 * * * \\
{[0.036]}\end{array}$ \\
\hline 1994-1998 Male mean & 0.463 & 0.604 & 0.44 & 0.583 & 0.389 & 0.442 \\
\hline 1994-1998 Female mean & 0.382 & 0.385 & 0.368 & 0.387 & 0.311 & 0.275 \\
\hline Observations & 109799 & 55487 & 95998 & 46832 & 873.677 & 74.392 \\
\hline \multicolumn{7}{|c|}{ Panel B: controlling for lagged $Y$} \\
\hline Female*(2009-2013) & $\begin{array}{c}-0.00457 \\
{[0.015]}\end{array}$ & $\begin{array}{l}0.0370^{*} \\
{[0.021]}\end{array}$ & $\begin{array}{l}-0.0172 \\
{[0.016]}\end{array}$ & $\begin{array}{l}0.0189 \\
{[0.021]}\end{array}$ & & \\
\hline Female*(2004-2008) & $\begin{array}{l}-0.0128 \\
{[0.015]}\end{array}$ & $\begin{array}{l}0.0272 \\
{[0.022]}\end{array}$ & $\begin{array}{l}-0.0231 \\
{[0.016]}\end{array}$ & $\begin{array}{l}0.00934 \\
{[0.023]}\end{array}$ & & \\
\hline Female*(1999-2003) & $\begin{array}{l}-0.0145 \\
{[0.016]}\end{array}$ & $\begin{array}{l}0.0331 \\
{[0.024]}\end{array}$ & $\begin{array}{l}-0.0183 \\
{[0.018]}\end{array}$ & $\begin{array}{c}0.0158 \\
{[0.026]}\end{array}$ & & \\
\hline Female baseline (1994-1998) & $\begin{array}{l}-0.0153 \\
{[0.014]}\end{array}$ & $\begin{array}{c}-0.0571^{* * *} \\
{[0.020]}\end{array}$ & $\begin{array}{l}-0.0152 \\
{[0.015]}\end{array}$ & $\begin{array}{c}-0.0506^{* *} \\
{[0.020]}\end{array}$ & & \\
\hline 1994-1998 Male mean & 0.463 & 0.604 & 0.44 & 0.583 & & \\
\hline 1994-1998 Female mean & 0.382 & 0.385 & 0.368 & 0.387 & & \\
\hline Observations & 109753 & 55457 & 95958 & 46806 & & \\
\hline
\end{tabular}

Pscore $>99.5$ corresponds to the sample of individuals who are predicted to have a propensity to be board members above the 99.5th percentile, based on their characteristics and estimates of how these characteristics affect board membership for men in the pre-period. The second sample selects individuals with earnings above the 98th percentile for three years in a row that also have a business degree. The regressions control for year dummies, age, age squared, potential experience dummies, and fixed individual characteristics (an indicator for whether the individual was working at the time of selection into his or her cohort, as well as marital status and presence of children at the time the individual was selected into his or her cohort). Standard errors [in brackets] clustered at the person level. *** $\mathrm{p}<0.01,{ }^{* *} \mathrm{p}<0.05, * \mathrm{p}<0.1$. 
Table 9: Gender Gaps Among Cohorts of Recent Graduates

\begin{tabular}{|c|c|c|c|c|c|c|}
\hline Sample: & Business & $\begin{array}{l}\text { t Graduate De } \\
\text { Business } \\
\text { law or social } \\
\text { studies } \\
\end{array}$ & Science & Business & $\begin{array}{l}\text { Graduate De } \\
\text { Business } \\
\text { law or social } \\
\text { studies } \\
\end{array}$ & ree in: \\
\hline \multirow[t]{2}{*}{ Cohort years: } & \multicolumn{3}{|c|}{ All } & \multicolumn{3}{|c|}{ Last 2 years only } \\
\hline & \multicolumn{6}{|c|}{ Panel A: Dependent variable: $\log$ ( annual earnings) } \\
\hline Female*(2009-2013) & $\begin{array}{l}0.0178 \\
{[0.020]}\end{array}$ & $\begin{array}{c}-0.00764 \\
{[0.013]}\end{array}$ & $\begin{array}{c}0.0218 \\
{[0.015]}\end{array}$ & $\begin{array}{c}0.0961 * * * \\
{[0.024]}\end{array}$ & $\begin{array}{c}0.0446 * * * \\
{[0.015]}\end{array}$ & $\begin{array}{c}0.0713 * * * \\
{[0.017]}\end{array}$ \\
\hline Female*(2004-2008) & $\begin{array}{c}-0.0446^{* *} \\
{[0.022]}\end{array}$ & $\begin{array}{c}-0.0511 * * * \\
{[0.014]}\end{array}$ & $\begin{array}{c}0.0361 * * \\
{[0.016]}\end{array}$ & $\begin{array}{c}-0.00217 \\
{[0.026]}\end{array}$ & $\begin{array}{l}-0.0240 \\
{[0.016]}\end{array}$ & $\begin{array}{c}0.0596 * * * \\
{[0.018]}\end{array}$ \\
\hline Female*(1999-2003) & $\begin{array}{l}-0.0210 \\
{[0.023]}\end{array}$ & $\begin{array}{c}-0.0465^{* * *} \\
{[0.014]}\end{array}$ & $\begin{array}{l}0.0104 \\
{[0.015]}\end{array}$ & $\begin{array}{l}0.0426 \\
{[0.028]}\end{array}$ & $\begin{array}{c}-0.00300 \\
{[0.016]}\end{array}$ & $\begin{array}{c}0.0593 * * * \\
{[0.017]}\end{array}$ \\
\hline Female (baseline 1994-1998) & $\begin{array}{c}-0.190 * * * \\
{[0.018]}\end{array}$ & $\begin{array}{c}-0.179 * * * \\
{[0.010]}\end{array}$ & $\begin{array}{c}-0.192 * * * \\
{[0.011]}\end{array}$ & $\begin{array}{c}-0.301 * * * \\
{[0.021]}\end{array}$ & $\begin{array}{c}-0.267 * * * \\
{[0.012]}\end{array}$ & $\begin{array}{c}-0.274 * * * \\
{[0.013]}\end{array}$ \\
\hline \multirow[t]{2}{*}{ Observations } & 87926 & 180573 & 136735 & 34818 & 71592 & 54146 \\
\hline & \multicolumn{6}{|c|}{ Panel B: Dependent variable: Married $(Y=1)$} \\
\hline Female*(2009-2013) & $\begin{array}{c}-0.0297 * \\
{[0.016]}\end{array}$ & $\begin{array}{c}-0.00139 \\
{[0.010]}\end{array}$ & $\begin{array}{c}-0.0318 * * * \\
{[0.011]}\end{array}$ & $\begin{array}{r}-0.0252 \\
{[0.022]}\end{array}$ & $\begin{array}{c}0.00541 \\
{[0.014]}\end{array}$ & $\begin{array}{c}-0.0457 * * * \\
{[0.015]}\end{array}$ \\
\hline Female*(2004-2008) & $\begin{array}{l}-0.0227 \\
{[0.016]}\end{array}$ & $\begin{array}{c}-0.00340 \\
{[0.010]}\end{array}$ & $\begin{array}{l}-0.0162 \\
{[0.012]}\end{array}$ & $\begin{array}{l}-0.0184 \\
{[0.022]}\end{array}$ & $\begin{array}{c}0.00566 \\
{[0.014]}\end{array}$ & $\begin{array}{l}-0.0216 \\
{[0.016]}\end{array}$ \\
\hline Female*(1999-2003) & $\begin{array}{l}-0.0227 \\
{[0.017]}\end{array}$ & $\begin{array}{l}0.00362 \\
{[0.011]}\end{array}$ & $\begin{array}{l}-0.0139 \\
{[0.011]}\end{array}$ & $\begin{array}{l}-0.0232 \\
{[0.024]}\end{array}$ & $\begin{array}{c}0.00608 \\
{[0.015]}\end{array}$ & $\begin{array}{c}-0.0255^{*} \\
{[0.015]}\end{array}$ \\
\hline Female (baseline 1994-1998) & $\begin{array}{c}0.0369 * * \\
{[0.014]}\end{array}$ & $\begin{array}{c}0.0103 \\
{[0.009]}\end{array}$ & $\begin{array}{c}0.0456^{* * *} \\
{[0.009]}\end{array}$ & $\begin{array}{c}0.0402 * * \\
{[0.020]}\end{array}$ & $\begin{array}{c}0.00557 \\
{[0.012]}\end{array}$ & $\begin{array}{c}0.0618 * * * \\
{[0.012]}\end{array}$ \\
\hline \multirow[t]{2}{*}{ Observations } & 90720 & 185044 & 139382 & 35753 & 73135 & 54993 \\
\hline & \multicolumn{6}{|c|}{ Panel C: Dependent variable: Number of children } \\
\hline Female*(2009-2013) & $\begin{array}{c}0.00373 \\
{[0.026]}\end{array}$ & $\begin{array}{l}0.0225 \\
{[0.017]}\end{array}$ & $\begin{array}{l}0.0282 \\
{[0.018]}\end{array}$ & $\begin{array}{c}0.00110 \\
{[0.036]}\end{array}$ & $\begin{array}{l}0.0295 \\
{[0.023]}\end{array}$ & $\begin{array}{l}0.0178 \\
{[0.026]}\end{array}$ \\
\hline Female*(2004-2008) & $\begin{array}{l}-0.0140 \\
{[0.025]}\end{array}$ & $\begin{array}{l}0.0110 \\
{[0.018]}\end{array}$ & $\begin{array}{l}0.0145 \\
{[0.019]}\end{array}$ & $\begin{array}{l}-0.0316 \\
{[0.035]}\end{array}$ & $\begin{array}{c}0.00605 \\
{[0.024]}\end{array}$ & $\begin{array}{c}-0.00449 \\
{[0.026]}\end{array}$ \\
\hline Female*(1999-2003) & $\begin{array}{c}-0.00793 \\
{[0.026]}\end{array}$ & $\begin{array}{c}0.0250 \\
{[0.018]}\end{array}$ & $\begin{array}{c}-0.00661 \\
{[0.017]}\end{array}$ & $\begin{array}{l}-0.0196 \\
{[0.037]}\end{array}$ & $\begin{array}{c}0.0311 \\
{[0.024]}\end{array}$ & $\begin{array}{l}-0.0333 \\
{[0.025]}\end{array}$ \\
\hline Female (baseline 1994-1998) & $\begin{array}{c}0.0277 \\
{[0.022]}\end{array}$ & $\begin{array}{c}0.0122 \\
{[0.014]}\end{array}$ & $\begin{array}{c}0.0575 * * * \\
{[0.013]}\end{array}$ & $\begin{array}{c}0.0642 * * \\
{[0.031]}\end{array}$ & $\begin{array}{c}0.0340 * \\
{[0.020]}\end{array}$ & $\begin{array}{c}0.117 * * * \\
{[0.019]}\end{array}$ \\
\hline Observations & 90720 & 185044 & 139382 & 35753 & 73135 & 54993 \\
\hline
\end{tabular}

Note: The first three columns include samples include 4 cohorts of males and females that completed a graduate degree from either a business program or a business, law or social studies program, or a study program in science, within the three first years after completing their degree. Outcomes are observed for a five year long period. We include two pre-reform cohorts (1994-1998 and 1999-2003), a during-reform cohort (2004-2008) and a post-reform cohorts (2009-2013). Regression includes controls for age, age squared, experience, experience squared, and year dummies, as well as two indicator variables that equals 1 if the individual was married or had any children before the first year of being observed. Standard errors are clustered at the person level. ${ }^{* * *} \mathrm{p}<0.01{ }^{* *} \mathrm{p}<0.05 .{ }^{*} \mathrm{p}<0.1$. 
Table 10: Awareness, Attitudes, and Expectations of Business Students, Fall 2013

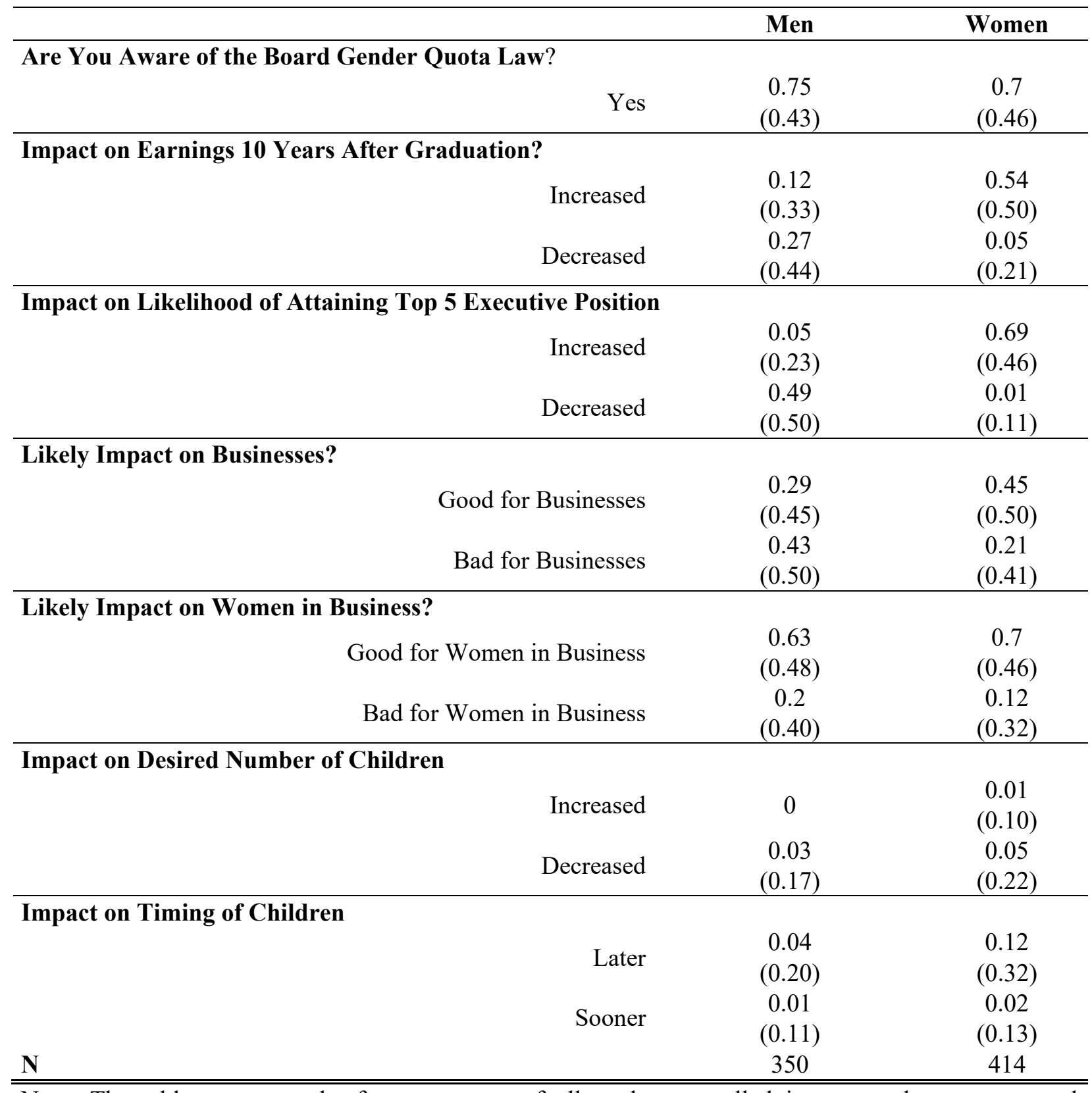

Note: The table report results from a survey of all students enrolled in any study program at the Norwegian School of Economics in the fall of 2013. A total of 3528 students received an e-mail with an invitation to answer a short survey, and a total of 764 students responded, 414 women and 350 men. 
Appendix Table A1: ASA Firms

\begin{tabular}{|c|c|c|c|c|c|c|c|c|}
\hline Year & $\begin{array}{l}\mathrm{N} \text { of ASA } \\
\text { Firms }\end{array}$ & $\begin{array}{c}\mathrm{N} \text { of ASA Firms, } \\
\text { conditional on } \\
\text { ASA in } 2003\end{array}$ & $\begin{array}{l}\text { Mean Percentage } \\
\text { Women on Board }\end{array}$ & $\begin{array}{c}\text { Median } \\
\text { Percentage } \\
\text { Women on Board }\end{array}$ & $\begin{array}{l}\text { Mean Number of } \\
\text { Women on Board }\end{array}$ & $\begin{array}{c}\text { Median Number } \\
\text { of Women on } \\
\text { Board }\end{array}$ & $\begin{array}{c}\text { Mean Board } \\
\text { Size }\end{array}$ & $\begin{array}{c}\text { Median } \\
\text { Board Size }\end{array}$ \\
\hline 1998 & 430 & 302 & 0.04 & 0.00 & 0.24 & 0 & 5.28 & 5 \\
\hline 1999 & 489 & 352 & 0.04 & 0.00 & 0.26 & 0 & 5.21 & 5 \\
\hline 2000 & 547 & 419 & 0.04 & 0.00 & 0.26 & 0 & 5.09 & 5 \\
\hline 2001 & 564 & 468 & 0.05 & 0.00 & 0.30 & 0 & 5.09 & 5 \\
\hline 2002 & 541 & 489 & 0.06 & 0.00 & 0.37 & 0 & 5.10 & 5 \\
\hline 2003 & 581 & 581 & 0.08 & 0.00 & 0.47 & 0 & 5.07 & 5 \\
\hline 2004 & 560 & 515 & 0.10 & 0.00 & 0.62 & 0 & 5.13 & 5 \\
\hline 2005 & 450 & 359 & 0.17 & 0.17 & 0.98 & 1 & 5.23 & 5 \\
\hline 2006 & 466 & 299 & 0.24 & 0.25 & 1.33 & 1 & 5.22 & 5 \\
\hline 2007 & 461 & 223 & 0.34 & 0.40 & 1.82 & 2 & 5.16 & 5 \\
\hline 2008 & 394 & 186 & 0.40 & 0.40 & 2.12 & 2 & 5.27 & 5 \\
\hline 2009 & 341 & 163 & 0.40 & 0.40 & 2.11 & 2 & 5.30 & 5 \\
\hline 2010 & 323 & 142 & 0.40 & 0.40 & 2.13 & 2 & 5.38 & 5 \\
\hline 2011 & 295 & 130 & 0.40 & 0.40 & 2.14 & 2 & 5.30 & 5 \\
\hline 2012 & 254 & 112 & 0.39 & 0.40 & 2.08 & 2 & 5.33 & 5 \\
\hline 2013 & 244 & 106 & 0.39 & 0.40 & 2.22 & 2 & 5.61 & 5 \\
\hline 2014 & 236 & 98 & 0.39 & 0.40 & 2.21 & 2 & 5.61 & 5 \\
\hline
\end{tabular}

Note: The data sources for the statistics are administrative registers. The Central Register of Establishments and Enterprises (CRE) are used to define the population and collect the variables and information. Outdated information resulting from time-lag in the registers may be a source of error. Such time-lags are caused by the fact that changes are often registered some time after they have happened. The registers are consequently not completely up-to-date all the time, leading to outdated information being used in the statistics. There is a time-lag between the cessation of an activity and its registration based on feedback in connection with data collection for structural business statistics or by linking administrative registers. Therefore, not all cessations in the period for which the figures are published are necessarily registered at the time of publication. A result of this is that the number of cessations will be too low, whereas the population figures as of January 1 in $\mathrm{t}+1$ will be too high. New registrations are in some cases done with a time lag. The respondent must state, in connection with new registrations, whether the activity is new or whether it is a change of ownership. When such information is lacking, duplicate checks are conducted to identify potential ownership changes. Not all ownership changes are found when these checks are conducted, and the number of newly established enterprises is presumably somewhat higher, compared with the number of new registrations. 
Appendix Table 2: Likelihood of exiting the ASA form by 2008

\begin{tabular}{|c|c|c|c|c|c|c|}
\hline Dependent Variable: & & Firm & no longer & $4 S A$ in 200 & $(Y=1)$ & \\
\hline Sample: & All $2003 \mathrm{AS}$ & firms stil & In existenc & in 2008 & $\begin{array}{l}\text { Board size } \\
\text { in } 2003<=5\end{array}$ & $\begin{array}{l}\text { Board size } \\
\text { in } 2003>5\end{array}$ \\
\hline $\begin{array}{l}\text { Percentage of women on } \\
\text { board in } 2003\end{array}$ & $\begin{array}{c}-0.679 * * * \\
{[0.197]}\end{array}$ & & $\begin{array}{c}-0.588 * * * \\
{[0.202]}\end{array}$ & & $\begin{array}{c}-0.0623 \\
{[0.284]}\end{array}$ & $\begin{array}{c}-0.652 * * \\
{[0.307]}\end{array}$ \\
\hline $\begin{array}{l}\text { No women on the board } \\
\text { in } 2003\end{array}$ & & $\begin{array}{c}0.203 * * * \\
{[0.053]}\end{array}$ & & $\begin{array}{c}0.185^{* * *} \\
{[0.054]}\end{array}$ & & \\
\hline Industry fixed effects & No & No & Yes & Yes & Yes & Yes \\
\hline Observations & 380 & 380 & 380 & 380 & 238 & 142 \\
\hline $\mathrm{R}$-squared & 0.030 & 0.038 & 0.097 & 0.104 & 0.057 & 0.241 \\
\hline
\end{tabular}

Note: The sample in first columns is restricted to the set of 380 firms that were ASA in 2003 and still existed in 2008. Column 5 focuses on the subset of these firms who had board size less or equal to 5 in 2003; column 6 focuses on the subset of these firms who had a board size greater than 5 in 2003 . p $<0.01, * *$ $\mathrm{p}<0.05, * \mathrm{p}<0.1$. 


\begin{tabular}{|c|c|c|c|c|c|c|c|c|c|c|c|c|}
\hline & \multicolumn{11}{|c|}{ Panel A: ASA Firms } & \\
\hline & \multicolumn{3}{|c|}{ Male } & & \multicolumn{3}{|c|}{ Female } & \multicolumn{5}{|c|}{ All } \\
\hline & $\begin{array}{l}1998- \\
2003\end{array}$ & $\begin{array}{l}2004- \\
2008\end{array}$ & $\begin{array}{l}2009- \\
2014\end{array}$ & & $\begin{array}{l}1998- \\
2003\end{array}$ & $\begin{array}{l}2004- \\
2008\end{array}$ & $\begin{array}{l}2009- \\
2014\end{array}$ & & $\begin{array}{l}1998- \\
2003\end{array}$ & $\begin{array}{l}2004- \\
2008\end{array}$ & $\begin{array}{l}2009- \\
2014\end{array}$ & \\
\hline \multicolumn{13}{|l|}{ Pre-appointment characteristics } \\
\hline Highest grade completed & 14.17 & 14.25 & 14.28 & & 13.96 & 14.95 & 15.01 & $*$ & 14.65 & 14.65 & 14.65 & $*$ \\
\hline Business degree & 0.24 & 0.28 & 0.25 & & 0.26 & 0.38 & 0.35 & $*$ & 0.34 & 0.30 & 0.30 & * \\
\hline MBA degree & 0.13 & 0.16 & 0.16 & & 0.13 & 0.18 & 0.18 & & 0.17 & 0.17 & 0.17 & \\
\hline Age & 41.77 & 41.78 & 42.59 & & 41.15 & 41.69 & 42.36 & & 41.73 & 42.47 & 42.47 & \\
\hline Log of earnings & 13.23 & 13.25 & 13.26 & & 12.75 & 13.07 & 13.16 & $*$ & 13.15 & 13.21 & 13.21 & \\
\hline $\begin{array}{l}\text { Earnings rank in cohort and } \\
\text { degree }\end{array}$ & 82.04 & 79.61 & 77.81 & $*$ & 66.99 & 70.37 & 71.83 & & 74.39 & 74.78 & 74.78 & * \\
\hline $\begin{array}{l}\text { Earnings rank in } \\
\text { cohort/degree }>90 \text { th percentile }\end{array}$ & 0.53 & 0.46 & 0.43 & $*$ & 0.22 & 0.32 & 0.34 & * & 0.38 & 0.38 & 0.38 & $*$ \\
\hline Top 5 earner in firm & 0.31 & 0.23 & 0.11 & $*$ & 0.10 & 0.21 & 0.20 & $*$ & 0.22 & 0.15 & 0.15 & * \\
\hline Human capital index & 0.031 & 0.029 & 0.021 & & 0.008 & 0.016 & 0.019 & $*$ & 0.022 & 0.020 & 0.020 & * \\
\hline \multicolumn{13}{|l|}{ Post-appointment characteristics } \\
\hline $\begin{array}{l}\text { Working more than } 30 \\
\text { hours/week }\end{array}$ & 0.90 & 0.89 & 0.91 & & 0.82 & 0.83 & 0.85 & & 0.86 & 0.88 & 0.88 & \\
\hline Log of earnings & 13.23 & 13.42 & 13.37 & $*$ & 12.84 & 13.16 & 13.20 & $*$ & 13.27 & 13.28 & 13.28 & 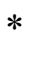 \\
\hline Earnings rank in cohort & 87.67 & 88.32 & 86.50 & & 77.45 & 82.05 & 80.87 & $*$ & 84.77 & 83.64 & 83.64 & \\
\hline $\begin{array}{l}\text { Earnings rank in cohort and } \\
\text { degree }\end{array}$ & 81.71 & 82.55 & 80.59 & & 68.79 & 73.68 & 74.48 & * & 77.53 & 77.48 & 77.48 & \\
\hline $\begin{array}{l}\text { Earnings rank in } \\
\text { cohort/degree }>90 \text { th percentile }\end{array}$ & 0.54 & 0.55 & 0.50 & & 0.32 & 0.37 & 0.39 & & 0.45 & 0.44 & 0.44 & * \\
\hline Married & 0.72 & 0.65 & 0.53 & $*$ & 0.63 & 0.60 & 0.54 & & 0.62 & 0.53 & 0.53 & * \\
\hline Has kids & 0.57 & 0.66 & 0.74 & $*$ & 0.55 & 0.66 & 0.71 & * & 0.66 & 0.73 & 0.72 & * \\
\hline Number of kids & 1.24 & 1.44 & 1.67 & $*$ & 1.14 & 1.38 & 1.44 & $*$ & 1.41 & 1.55 & 1.55 & $*$ \\
\hline $\mathrm{N}$ individuals & 717 & 308 & 171 & & 164 & 383 & 178 & & 881 & 691 & 349 & \\
\hline $\mathrm{N}$ boards & 390 & 233 & 119 & & 130 & 301 & 131 & & 520 & 534 & 250 & \\
\hline $\begin{array}{l}\text { N observations (board } \\
\text { position*year) }\end{array}$ & 763 & 321 & 175 & & 168 & 419 & 181 & & 931 & 740 & 356 & \\
\hline
\end{tabular}

Note: The table report means characteristics for board members in all ASA firms in the three indicated periods which did not appear on either ASA or AS boards in any of the preceeding periods. Stars in the table indicate that pre- (1998-2003) and post- (2004-2014) reform means are statistically different at the 5\% level of significance. 
Appendix Table A3.b: Characteristics of Newly Appointed Board Members

\begin{tabular}{|c|c|c|c|c|c|c|c|c|c|c|c|c|}
\hline & \multicolumn{12}{|c|}{ Panel B: ASA Firms in 2003} \\
\hline & \multicolumn{3}{|c|}{ Male } & \multicolumn{4}{|c|}{ Female } & \multicolumn{4}{|c|}{ All } & \\
\hline & $\begin{array}{l}1998- \\
2003\end{array}$ & $\begin{array}{l}2004- \\
2008\end{array}$ & $\begin{array}{l}2009- \\
2014\end{array}$ & & $\begin{array}{l}1998- \\
2003\end{array}$ & $\begin{array}{l}2004- \\
2008\end{array}$ & $\begin{array}{l}2009- \\
2014\end{array}$ & & $\begin{array}{l}1998- \\
2003\end{array}$ & $\begin{array}{l}2004- \\
2008\end{array}$ & $\begin{array}{l}2009- \\
2014\end{array}$ & \\
\hline \multicolumn{13}{|c|}{$\underline{\text { Pre-appointment characteristics }}$} \\
\hline Highest grade completed & 14.14 & 14.09 & 14.17 & & 14.68 & 14.56 & 14.56 & * & 14.38 & 14.31 & 14.31 & \\
\hline Business degree & 0.24 & 0.24 & 0.29 & & 0.36 & 0.31 & 0.31 & & 0.30 & 0.30 & 0.30 & \\
\hline MBA degree & 0.12 & 0.11 & 0.18 & & 0.15 & 0.15 & 0.15 & & 0.13 & 0.17 & 0.17 & \\
\hline Age & 41.81 & 42.37 & 42.19 & & 42.24 & 41.94 & 41.94 & & 42.30 & 42.10 & 42.10 & \\
\hline Log of earnings & 13.23 & 13.23 & 13.32 & & 13.04 & 13.13 & 13.13 & $*$ & 13.14 & 13.26 & 13.26 & \\
\hline $\begin{array}{l}\text { Earnings rank in cohort and } \\
\text { degree }\end{array}$ & 80.84 & 78.64 & 80.66 & & 70.58 & 73.45 & 73.45 & & 74.63 & 78.14 & 78.14 & \\
\hline $\begin{array}{l}\text { Earnings rank in } \\
\text { cohort/degree }>90 \text { th } \\
\text { percentile }\end{array}$ & 0.53 & 0.42 & 0.44 & $*$ & 0.32 & 0.31 & 0.30 & $*$ & 0.37 & 0.39 & 0.39 & * \\
\hline Top 5 earner in firm & 0.30 & 0.20 & 0.17 & $*$ & 0.18 & 0.16 & 0.16 & $*$ & 0.19 & 0.17 & 0.17 & $*$ \\
\hline Human capital index & 0.031 & 0.020 & 0.028 & $*$ & 0.017 & 0.011 & 0.010 & & 0.018 & 0.022 & 0.020 & * \\
\hline \multicolumn{13}{|c|}{$\underline{\text { Post-appointment characteristics }}$} \\
\hline $\begin{array}{l}\text { Working more than } 30 \\
\text { hours/week }\end{array}$ & 0.88 & 0.93 & 0.92 & $*$ & 0.84 & 0.92 & 0.92 & & 0.88 & 0.92 & 0.92 & * \\
\hline Log of earnings & 13.21 & 13.33 & 13.35 & $*$ & 13.11 & 13.16 & 13.16 & $*$ & 13.22 & 13.28 & 13.28 & $*$ \\
\hline Earnings rank in cohort & 86.82 & 87.95 & 85.32 & & 80.96 & 80.41 & 80.41 & & 84.46 & 83.60 & 83.60 & \\
\hline $\begin{array}{l}\text { Earnings rank in cohort and } \\
\text { degree }\end{array}$ & 80.64 & 81.46 & 80.57 & & 73.43 & 74.51 & 74.51 & & 77.45 & 78.45 & 78.45 & \\
\hline $\begin{array}{l}\text { Earnings rank in } \\
\text { cohort/degree }>90 \text { th } \\
\text { percentile }\end{array}$ & 0.54 & 0.48 & 0.49 & & 0.36 & 0.39 & 0.38 & & 0.42 & 0.45 & 0.45 & \\
\hline Married & 0.71 & 0.65 & 0.58 & $*$ & 0.60 & 0.53 & 0.53 & & 0.63 & 0.56 & 0.56 & * \\
\hline Has kids & 0.56 & 0.69 & 0.73 & $*$ & 0.67 & 0.72 & 0.72 & $*$ & 0.68 & 0.73 & 0.73 & $*$ \\
\hline Number of kids & 1.24 & 1.47 & 1.56 & $*$ & 1.36 & 1.42 & 1.42 & $*$ & 1.41 & 1.51 & 1.51 & * \\
\hline $\mathrm{N}$ individuals & 660 & 263 & 231 & & 154 & 256 & 130 & & 814 & 519 & 361 & \\
\hline $\mathrm{N}$ boards & 333 & 178 & 137 & & 121 & 188 & 93 & & 454 & 366 & 230 & \\
\hline $\begin{array}{l}\mathrm{N} \text { observations (board } \\
\text { position*year) }\end{array}$ & 701 & 271 & 241 & & 158 & 270 & 130 & & 859 & 541 & 371 & \\
\hline
\end{tabular}

Note: The table report means characteristics for board members in all ASA firms that were ASA in 2003 (intentto-treat sample) in the three indicated periods, which did not appear on either ASA or AS boards in any of the preceeding perdiods. Stars in the table indicate that pre- (1998-2003) and post- (2004-2014) reform means are statistically different at the $5 \%$ level of significance. 
Appendix Table A4: Employment at ASA versus outside of ASA groups, 2002-2014

\begin{tabular}{|c|c|c|c|c|c|c|}
\hline Sample: & \multicolumn{2}{|c|}{$\begin{array}{l}\text { Employment in } \\
\text { ASA Business } \\
\text { Groups } \\
\end{array}$} & \multicolumn{2}{|c|}{$\begin{array}{c}\text { Employment } \\
\text { outside of ASA } \\
\text { Business Groups }\end{array}$} & \multicolumn{2}{|c|}{$\begin{array}{l}\text { Employment } \\
\text { in ASA Firms }\end{array}$} \\
\hline \multirow[t]{2}{*}{ Number of employees: } & \multicolumn{2}{|c|}{1429588} & \multicolumn{2}{|c|}{26544570} & \multicolumn{2}{|c|}{628382} \\
\hline & Mean & Std. Dev. & Mean & St. Dev. & Mean & St. Dev. \\
\hline Age & 42.421 & 11.109 & 41.394 & 12.029 & 43.443 & 10.721 \\
\hline Experience & 16.286 & 10.176 & 15.153 & 10.767 & 16.955 & 10.081 \\
\hline \multicolumn{7}{|l|}{ Share: } \\
\hline Women & 0.301 & 0.459 & 0.486 & 0.500 & 0.352 & 0.478 \\
\hline Working full-time & 0.924 & 0.264 & 0.747 & 0.435 & 0.942 & 0.233 \\
\hline Working part-time & 0.076 & 0.264 & 0.253 & 0.435 & 0.058 & 0.233 \\
\hline With MBA & 0.043 & 0.204 & 0.013 & 0.112 & 0.071 & 0.257 \\
\hline Women with MBA & 0.014 & 0.117 & 0.005 & 0.067 & 0.022 & 0.145 \\
\hline Married & 0.506 & 0.500 & 0.473 & 0.499 & 0.548 & 0.498 \\
\hline With kids & 0.546 & 0.498 & 0.523 & 0.499 & 0.565 & 0.496 \\
\hline Log(Earnings) & 13.092 & 0.621 & 12.647 & 0.734 & 13.252 & 0.615 \\
\hline
\end{tabular}

Note: The table summarizes employee characteristics in ASA business groups and ASA firms, versus outside ASA business groups. Data covers the time period 2002 to 2014. 
Appendix Table A5: Employment at ASA Business Groups and Firms, 2003-2014 (conditional on ASA in 2003)

\begin{tabular}{|c|c|c|c|c|c|c|}
\hline \multirow{2}{*}{$\begin{array}{l}\text { Sample: } \\
\text { Variable: }\end{array}$} & \multicolumn{3}{|c|}{ ASA Business Groups } & \multicolumn{3}{|c|}{ ASA Firms } \\
\hline & $\mathrm{N}$ & Mean & Std. Dev. & $\mathrm{N}$ & Mean & Std. Dev. \\
\hline Average employee age & 1674 & 42.86 & 2.77 & 2147 & 44.59 & 2.99 \\
\hline Share of employees with MBAs & 1674 & 0.04 & 0.05 & 2145 & 0.09 & 0.08 \\
\hline Share of employees that are married & 1674 & 0.51 & 0.08 & 2147 & 0.57 & 0.09 \\
\hline Share of employees with kids & 1674 & 0.55 & 0.09 & 2147 & 0.57 & 0.10 \\
\hline Average age of female employees & 1569 & 42.12 & 2.96 & 1868 & 43.56 & 3.73 \\
\hline \multicolumn{7}{|l|}{ Share of employees that are: } \\
\hline women & 1674 & 0.28 & 0.15 & 2147 & 0.36 & 0.14 \\
\hline women with MBAs & 1674 & 0.01 & 0.03 & 2145 & 0.03 & 0.03 \\
\hline married women & 1674 & 0.14 & 0.08 & 2147 & 0.19 & 0.09 \\
\hline women with kids & 1674 & 0.15 & 0.08 & 2147 & 0.20 & 0.08 \\
\hline women working part-time & 1674 & 0.04 & 0.06 & 2147 & 0.04 & 0.06 \\
\hline \multicolumn{7}{|l|}{$\begin{array}{l}\text { Share of female employees earning above } \\
\text { the .... in the earnings distribution: }\end{array}$} \\
\hline 75th percentile & 1530 & 0.13 & 0.06 & 1773 & 0.11 & 0.05 \\
\hline 90th percentile & 1392 & 0.05 & 0.03 & 1426 & 0.04 & 0.02 \\
\hline 95th percentile & 1206 & 0.02 & 0.02 & 1028 & 0.02 & 0.01 \\
\hline Woman is top earner $(\mathrm{Y}=1)$ & 1674 & 0.05 & 0.21 & 2147 & 0.06 & 0.24 \\
\hline Number of women among top 5 earners & 1674 & 0.46 & 0.77 & 2147 & 0.60 & 0.83 \\
\hline
\end{tabular}

Note: In all rows except the last 2, observations are weighted by the number of employees in the business group or firm in 2003. 


\section{Panel A: Intent-to-Treat ASA Business Groups}

\begin{tabular}{|c|c|c|c|c|c|c|c|c|c|c|}
\hline \multicolumn{2}{|c|}{ Dependent variable: } & \multicolumn{4}{|c|}{ Share of employees that are: } & \multicolumn{3}{|c|}{$\begin{array}{c}\text { Share of female employees with } \\
\text { earning above the .... } \\
\text { in the earnings distribution: }\end{array}$} & \multirow{2}{*}{$\begin{array}{c}\text { Women is } \\
\text { top } \\
\text { earner? } \\
(\mathrm{Y}=1)\end{array}$} & \multirow{2}{*}{$\begin{array}{c}\text { Number } \\
\text { of } \\
\text { women } \\
\text { among } \\
\text { the top 5 } \\
\text { earners }\end{array}$} \\
\hline & $\begin{array}{l}\text { Percent } \\
\text { women on } \\
\text { the board }\end{array}$ & women & $\begin{array}{l}\text { women } \\
\text { with } \\
\text { MBA }\end{array}$ & $\begin{array}{l}\text { women } \\
\text { with } \\
\text { kids }\end{array}$ & $\begin{array}{c}\text { women } \\
\text { working } \\
\text { part-time }\end{array}$ & $\begin{array}{c}75 \text { th } \\
\text { percentile }\end{array}$ & $\begin{array}{c}\text { 90th } \\
\text { percentile }\end{array}$ & $\begin{array}{c}\text { 95th } \\
\text { percentile }\end{array}$ & & \\
\hline 1998 & 0.04 & 0.287 & 0.004 & 0.101 & 0.067 & 0.077 & 0.022 & 0.008 & 0.032 & 0.302 \\
\hline 1999 & 0.04 & 0.289 & 0.005 & 0.106 & 0.065 & 0.083 & 0.024 & 0.010 & 0.042 & 0.367 \\
\hline 2000 & 0.05 & 0.284 & 0.005 & 0.115 & 0.066 & 0.091 & 0.027 & 0.012 & 0.033 & 0.328 \\
\hline 2001 & 0.05 & 0.285 & 0.006 & 0.119 & 0.062 & 0.096 & 0.030 & 0.014 & 0.056 & 0.377 \\
\hline 2002 & 0.07 & 0.301 & 0.007 & 0.132 & 0.066 & 0.101 & 0.031 & 0.014 & 0.049 & 0.364 \\
\hline 2003 & 0.08 & 0.299 & 0.008 & 0.135 & 0.065 & 0.106 & 0.032 & 0.015 & 0.056 & 0.414 \\
\hline 2004 & 0.11 & 0.305 & 0.008 & 0.144 & 0.064 & 0.107 & 0.033 & 0.014 & 0.036 & 0.388 \\
\hline 2005 & 0.16 & 0.308 & 0.009 & 0.150 & 0.060 & 0.113 & 0.037 & 0.016 & 0.040 & 0.410 \\
\hline 2006 & 0.20 & 0.327 & 0.010 & 0.171 & 0.072 & 0.130 & 0.042 & 0.019 & 0.062 & 0.454 \\
\hline 2007 & 0.26 & 0.320 & 0.011 & 0.156 & 0.059 & 0.131 & 0.045 & 0.020 & 0.060 & 0.504 \\
\hline 2008 & 0.29 & 0.317 & 0.012 & 0.165 & 0.059 & 0.132 & 0.045 & 0.022 & 0.060 & 0.485 \\
\hline 2009 & 0.29 & 0.316 & 0.013 & 0.173 & 0.054 & 0.138 & 0.049 & 0.022 & 0.071 & 0.533 \\
\hline 2010 & 0.27 & 0.316 & 0.015 & 0.178 & 0.056 & 0.141 & 0.050 & 0.022 & 0.073 & 0.557 \\
\hline 2011 & 0.27 & 0.319 & 0.015 & 0.189 & 0.067 & 0.148 & 0.054 & 0.024 & 0.057 & 0.605 \\
\hline 2012 & 0.26 & 0.320 & 0.016 & 0.188 & 0.052 & 0.155 & 0.056 & 0.026 & 0.072 & 0.691 \\
\hline 2013 & 0.25 & 0.326 & 0.017 & 0.203 & 0.067 & 0.166 & 0.060 & 0.029 & 0.096 & 0.733 \\
\hline 2014 & 0.26 & 0.317 & 0.020 & 0.199 & 0.045 & 0.168 & 0.065 & 0.031 & 0.079 & 0.673 \\
\hline
\end{tabular}

Note: Sample in Panel A includes business groups that were ASA in 2003 (intent-to-treat sample) and covers the time period 1998 to 2014; Sample in Panel B includes firms that were ASA in 2003 (intent-to-treat sample) and covers the time period 1998 to 2014. In each panel, data is collapsed at the year level, with observations weighted by employment in the business group (Panel A) or firm (Panel B) in 2003 in all columns except the first one and the last two. 


\begin{tabular}{|c|c|c|c|c|c|c|c|c|c|c|}
\hline & & & & Panel & B: Intent- & o-Treat ASA & A Firms & & & \\
\hline Depen & ent variable: & Sha & re of emp & loyees tha & it are: & $\begin{array}{r}\text { Share of } \mathrm{f} \\
\text { earni } \\
\text { in the e }\end{array}$ & $\begin{array}{l}\text { emale emplo } \\
\text { ing above th } \\
\text { arnings distr }\end{array}$ & $\begin{array}{l}\text { oyees with } \\
\text { e .... } \\
\text { ibution: }\end{array}$ & & $\begin{array}{c}\text { Number } \\
\text { of }\end{array}$ \\
\hline & $\begin{array}{c}\text { Percent } \\
\text { women on } \\
\text { the board }\end{array}$ & women & $\begin{array}{l}\text { women } \\
\text { with } \\
\text { MBA }\end{array}$ & $\begin{array}{l}\text { women } \\
\text { with } \\
\text { kids }\end{array}$ & $\begin{array}{c}\text { working } \\
\text { part- } \\
\text { time }\end{array}$ & $\begin{array}{c}75 \text { th } \\
\text { percentile }\end{array}$ & $\begin{array}{c}\text { 90th } \\
\text { percentile }\end{array}$ & $\begin{array}{c}\text { 95th } \\
\text { percentile }\end{array}$ & $\begin{array}{l}\text { is top } \\
\text { earner? } \\
(\mathrm{Y}=1)\end{array}$ & $\begin{array}{l}\text { among } \\
\text { the top } 5 \\
\text { earners }\end{array}$ \\
\hline 1998 & 0.04 & 0.290 & 0.007 & 0.107 & 0.050 & 0.061 & 0.020 & 0.008 & 0.045 & 0.405 \\
\hline 1999 & 0.04 & 0.291 & 0.007 & 0.112 & 0.046 & 0.067 & 0.021 & 0.010 & 0.046 & 0.452 \\
\hline 2000 & 0.05 & 0.297 & 0.008 & 0.127 & 0.048 & 0.071 & 0.021 & 0.010 & 0.041 & 0.448 \\
\hline 2001 & 0.05 & 0.300 & 0.010 & 0.134 & 0.046 & 0.074 & 0.025 & 0.012 & 0.055 & 0.481 \\
\hline 2002 & 0.07 & 0.339 & 0.012 & 0.156 & 0.053 & 0.083 & 0.025 & 0.013 & 0.049 & 0.484 \\
\hline 2003 & 0.08 & 0.338 & 0.014 & 0.159 & 0.054 & 0.088 & 0.028 & 0.014 & 0.058 & 0.513 \\
\hline 2004 & 0.11 & 0.336 & 0.014 & 0.164 & 0.051 & 0.091 & 0.030 & 0.014 & 0.046 & 0.461 \\
\hline 2005 & 0.16 & 0.337 & 0.016 & 0.168 & 0.047 & 0.095 & 0.032 & 0.014 & 0.041 & 0.487 \\
\hline 2006 & 0.20 & 0.339 & 0.019 & 0.175 & 0.043 & 0.102 & 0.034 & 0.016 & 0.062 & 0.485 \\
\hline 2007 & 0.26 & 0.355 & 0.033 & 0.196 & 0.047 & 0.117 & 0.039 & 0.017 & 0.063 & 0.535 \\
\hline 2008 & 0.29 & 0.347 & 0.025 & 0.187 & 0.041 & 0.129 & 0.044 & 0.021 & 0.061 & 0.582 \\
\hline 2009 & 0.29 & 0.346 & 0.027 & 0.196 & 0.037 & 0.118 & 0.040 & 0.019 & 0.066 & 0.639 \\
\hline 2010 & 0.27 & 0.343 & 0.028 & 0.204 & 0.035 & 0.113 & 0.040 & 0.019 & 0.069 & 0.672 \\
\hline 2011 & 0.27 & 0.358 & 0.031 & 0.220 & 0.032 & 0.120 & 0.041 & 0.018 & 0.055 & 0.700 \\
\hline 2012 & 0.26 & 0.362 & 0.035 & 0.230 & 0.032 & 0.122 & 0.040 & 0.018 & 0.064 & 0.787 \\
\hline 2013 & 0.25 & 0.393 & 0.043 & 0.259 & 0.033 & 0.127 & 0.044 & 0.020 & 0.085 & 0.822 \\
\hline 2014 & 0.26 & 0.396 & 0.044 & 0.257 & 0.047 & 0.131 & 0.046 & 0.023 & 0.079 & 0.721 \\
\hline
\end{tabular}

Note: Sample in Panel A includes business groups that were ASA in 2003 (intent-to-treat sample) and covers the time period 1998 to 2014; Sample in Panel B includes firms that were ASA in 2003 (intent-to-treat sample) and covers the time period 1998 to 2014. In each panel, data is collapsed at the year level, with observations weighted by employment in the business group (Panel A) or firm (Panel B) in 2003 in all columns except the first one and the last two. 
Appendix Table A7: First-Stage Regressions

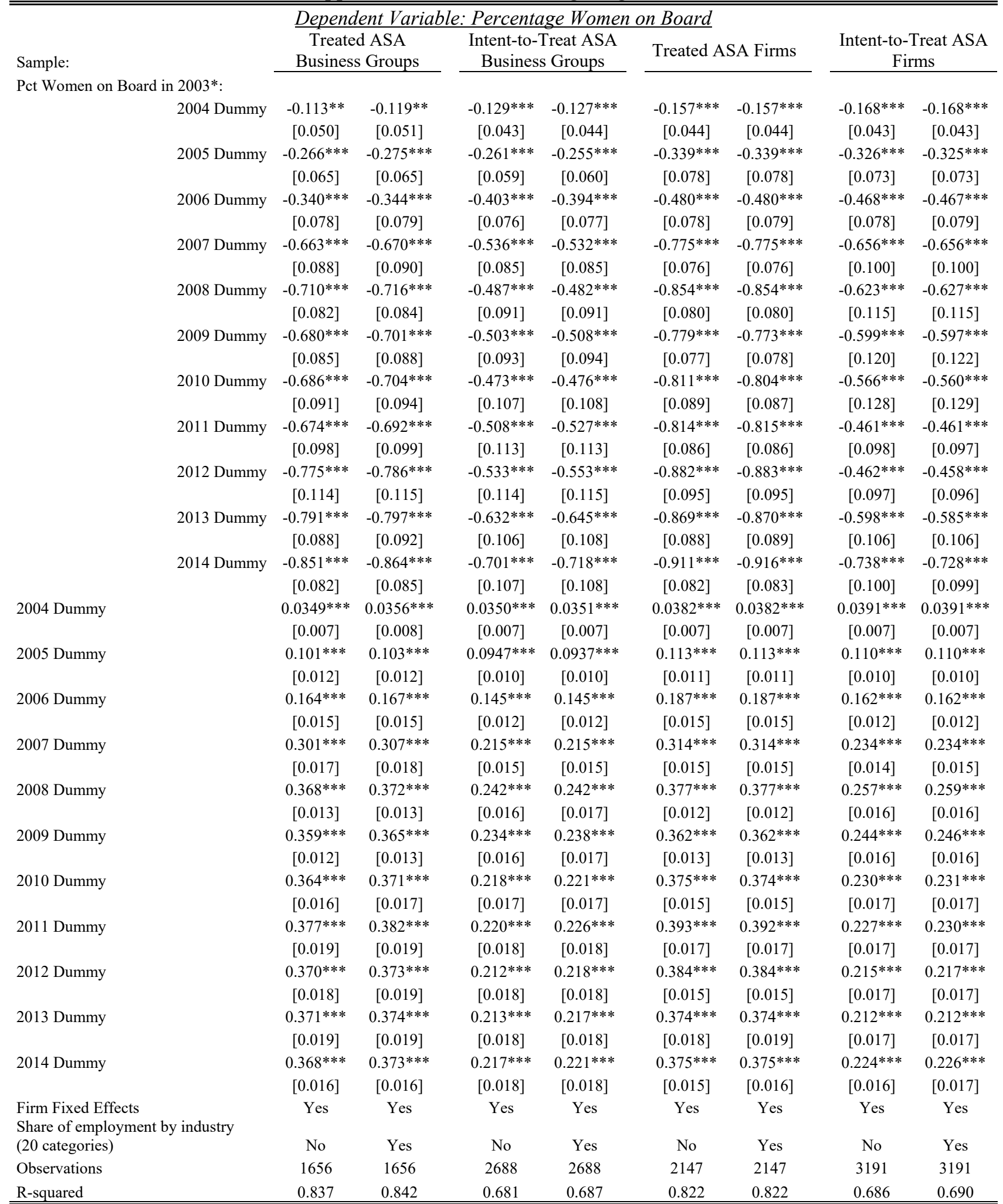

Note: Sample in columns 1 and 2 includes business groups that are ASA in the current year and were ASA in 2003 (treated sample); sample in columns 3 and 4 includes all business groups that were ASA in 2003 (intent-to-treat sample); sample in columns 5 and 6 includes firms that are ASA in the current year and were ASA in 2003 (treated sample); sample in columns 7 and 8 includes all firms that were ASA in 2003 (intent-to-treat sample). Standard errors are clustered at the parent company (columns 1 to 4 ) or firm (columns 5 to 8 ) level. *** $\mathrm{p}<0.01,{ }^{* *} \mathrm{p}<0.05,{ }^{*} \mathrm{p}<0.1$. 


\section{Panel A: ASA Business Groups}

\begin{tabular}{|c|c|c|c|c|c|c|c|c|c|}
\hline \multirow[t]{2}{*}{ Dependent variable: } & \multicolumn{4}{|c|}{ Share of employees that are: } & \multicolumn{3}{|c|}{$\begin{array}{c}\text { Share of female employees with } \\
\text { earning above the .... } \\
\text { in the earnings distribution: }\end{array}$} & \multirow{2}{*}{$\begin{array}{l}\text { Women } \\
\text { is top } \\
\text { earner? } \\
(Y=1)\end{array}$} & \multirow{2}{*}{$\begin{array}{c}\text { Number } \\
\text { of women } \\
\text { among } \\
\text { top } 5 \\
\text { earners }\end{array}$} \\
\hline & women & $\begin{array}{r}\text { women } \\
\text { with } M B A\end{array}$ & $\begin{array}{r}\text { women } \\
\text { with kids }\end{array}$ & $\begin{array}{r}\text { Women } \\
\text { working } \\
\text { part-time }\end{array}$ & $\begin{array}{c}75 \text { th } \\
\text { percentile }\end{array}$ & $\begin{array}{c}\text { 90th } \\
\text { percentile }\end{array}$ & $\begin{array}{c}95 \text { th } \\
\text { percentile }\end{array}$ & & \\
\hline Percent women on board in 2003 & $\begin{array}{c}0.386 * * * \\
{[0.111]}\end{array}$ & $\begin{array}{c}0.020 * * * \\
{[0.006]}\end{array}$ & $\begin{array}{c}0.166^{* * *} \\
{[0.049]}\end{array}$ & $\begin{array}{c}0.0715 * \\
{[0.037]}\end{array}$ & $\begin{array}{c}0.0250 \\
{[0.018]}\end{array}$ & $\begin{array}{c}0.0015 \\
{[0.010]}\end{array}$ & $\begin{array}{c}0.0075 \\
{[0.007]}\end{array}$ & $\begin{array}{c}0.185^{*} \\
{[0.105]}\end{array}$ & $\begin{array}{c}0.451 \\
{[0.363]}\end{array}$ \\
\hline Observations & 599 & 599 & 599 & 599 & 521 & 470 & 403 & 599 & 599 \\
\hline R-squared & 0.511 & 0.291 & 0.392 & 0.687 & 0.461 & 0.218 & 0.120 & 0.045 & 0.073 \\
\hline \multirow[t]{2}{*}{ Dependent variable: } & \multicolumn{4}{|c|}{ Share of employees that are: } & \multicolumn{3}{|c|}{$\begin{array}{c}\text { Share of female employees with } \\
\text { earning above the .... } \\
\text { in the earnings distribution: }\end{array}$} & \multirow{2}{*}{$\begin{array}{l}\text { Women is } \\
\text { top } \\
\text { earner? } \\
(Y=1) \\
\end{array}$} & \multirow{2}{*}{$\begin{array}{c}\text { Number } \\
\text { of women } \\
\text { among } \\
\text { top } 5 \\
\text { earners }\end{array}$} \\
\hline & women & $\begin{array}{r}\text { Women } \\
\text { with } M B A \\
\end{array}$ & $\begin{array}{r}\text { women } \\
\text { with kids }\end{array}$ & $\begin{array}{r}\text { women working } \\
\text { part-time }\end{array}$ & $\begin{array}{c}75 \text { th } \\
\text { percentile }\end{array}$ & $\begin{array}{c}\text { 90th } \\
\text { percentile }\end{array}$ & $\begin{array}{c}95 \text { th } \\
\text { percentile }\end{array}$ & & \\
\hline Percent women on board in 2003 & $\begin{array}{c}0.119 \\
{[0.097]}\end{array}$ & $\begin{array}{c}0.0065 \\
{[0.007]}\end{array}$ & $\begin{array}{l}0.0429 \\
{[0.052]}\end{array}$ & $\begin{array}{c}-0.0286 \\
{[0.041]}\end{array}$ & $\begin{array}{c}0.0061 \\
{[0.034]}\end{array}$ & $\begin{array}{c}0.0033 \\
{[0.017]}\end{array}$ & $\begin{array}{c}0.0032 \\
{[0.011]}\end{array}$ & $\begin{array}{c}0.157^{*} \\
{[0.092]}\end{array}$ & $\begin{array}{c}0.358 \\
{[0.336]}\end{array}$ \\
\hline Observations & 758 & 758 & 758 & 758 & 595 & 467 & 352 & 758 & 758 \\
\hline R-squared & 0.456 & 0.165 & 0.296 & 0.291 & 0.284 & 0.146 & 0.133 & 0.033 & 0.050 \\
\hline
\end{tabular}

Note: Sample in Panel A is restricted to business groups where parent company was ASA in 2002 and 2003. Sample in Panel B is restricted to firms that were ASA in 2002 and 2003. All regressions include year fixed effects and control for the share of employees in each of 20 different industry categories. Observations in all columns except the last 2 are weighted by total employment in the business group (Panel A) or firm (Panel B) in 2003. Standard errors are clustered at the business group (Panel A) or firm (Panel B) level. *** $\mathrm{p}<0.01,{ }^{* *} \mathrm{p}<0.05,{ }^{*} \mathrm{p}<0.1$. 


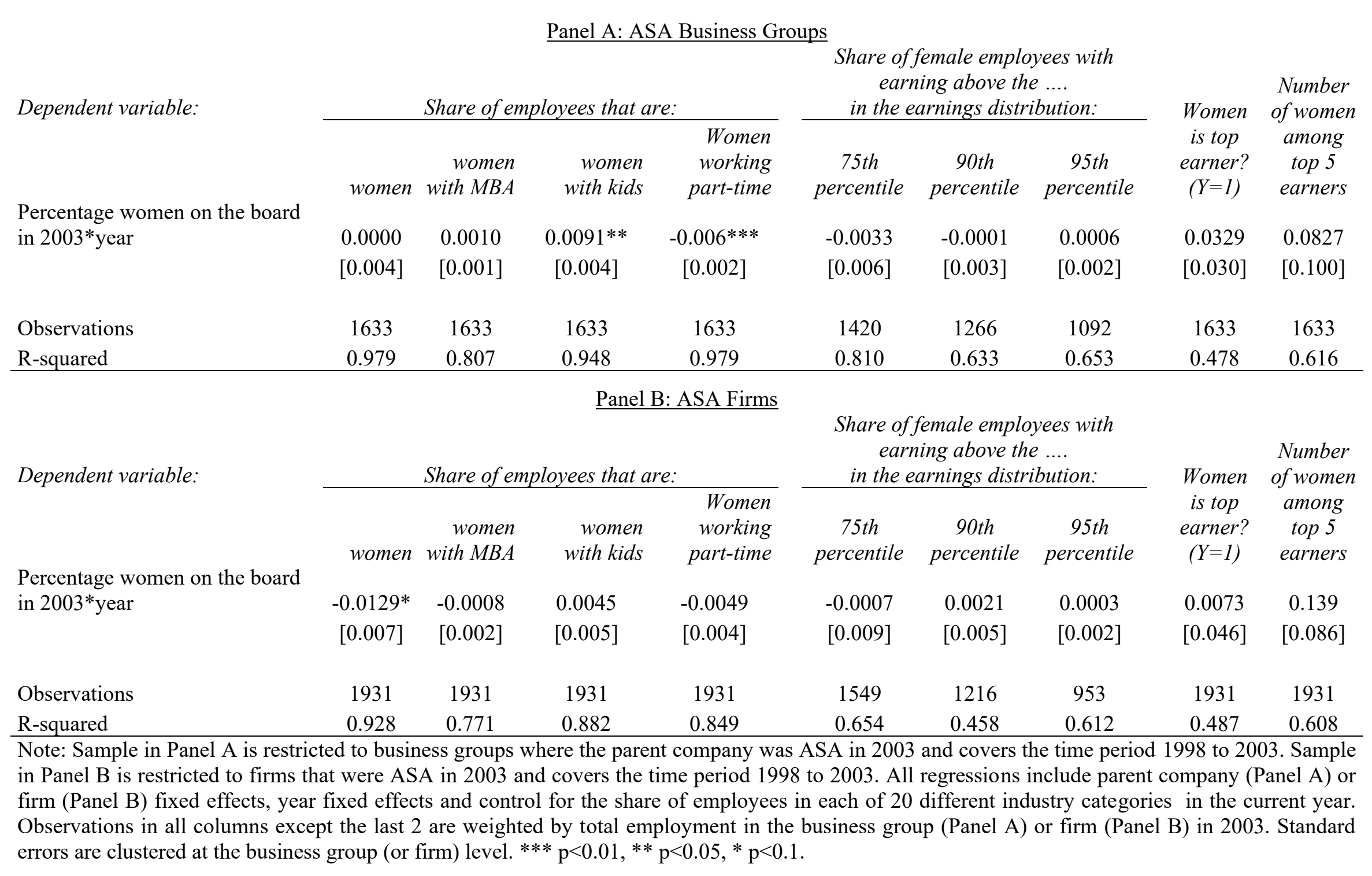


Appendix Table A10: Gender Gaps among Top Business Earners, Ages 35-55

\begin{tabular}{|c|c|c|c|c|}
\hline \multicolumn{5}{|c|}{ Dependent variable: Log (annual earnings) } \\
\hline \multirow{2}{*}{$\begin{array}{l}\text { Sample: } \\
\text { Affected group: }\end{array}$} & \multicolumn{2}{|c|}{ All } & \multicolumn{2}{|c|}{ Dropping Board Members } \\
\hline & Pscore $>99.5$ & P98 \& bus & Pscore $>99.5$ & P98 \& bus \\
\hline \multicolumn{5}{|l|}{ Basic Specification } \\
\hline \multirow[t]{2}{*}{ Female*(2004-2014) } & 0.0557 & 0.002 & -0.0202 & -0.0985 \\
\hline & {$[0.044]$} & {$[0.061]$} & {$[0.045]$} & {$[0.070]$} \\
\hline \multirow[t]{2}{*}{ Female baseline (1993-2004) } & $-0.159 * * *$ & $-0.104 * *$ & $-0.161 * * *$ & -0.0845 \\
\hline & {$[0.039]$} & {$[0.052]$} & [0.039] & {$[0.060]$} \\
\hline 1993-2003 Male mean & 13.60 & 13.57 & 13.54 & 13.51 \\
\hline 1993-2003 Female mean & 13.37 & 13.41 & 13.32 & 13.38 \\
\hline$N$ & 97353 & 48413 & 85546 & 40771 \\
\hline \multicolumn{5}{|l|}{ Controlling for lagged $\mathrm{Y}$} \\
\hline \multirow[t]{2}{*}{ Female*(2004-2014) } & 0.0125 & 0.0134 & -0.0076 & -0.012 \\
\hline & {$[0.016]$} & {$[0.026]$} & {$[0.017]$} & {$[0.031]$} \\
\hline \multirow[t]{2}{*}{ Female baseline (1993-2004) } & $-0.0381 * * *$ & -0.0372 & $-0.0428 * * *$ & -0.0389 \\
\hline & {$[0.015]$} & {$[0.024]$} & {$[0.015]$} & {$[0.028]$} \\
\hline$N$ & 97008 & 48278 & 85228 & 40645 \\
\hline \multicolumn{5}{|c|}{ Dependent variable: Top 5 earner in firm and year $(Y=1)$} \\
\hline Sample: & \multicolumn{2}{|c|}{ All } & \multicolumn{2}{|c|}{ Dropping Board Members } \\
\hline Affected group: & Pscore $>99.5$ & P98 \& bus & Pscore $>99.5$ & P98 \& bus \\
\hline \multicolumn{5}{|l|}{ Basic Specification } \\
\hline \multirow[t]{2}{*}{ Female*(2004-2014) } & 0.00724 & 0.059 & -0.0178 & 0.0422 \\
\hline & {$[0.037]$} & {$[0.055]$} & {$[0.038]$} & {$[0.057]$} \\
\hline \multirow[t]{2}{*}{ Female baseline (1993-2004) } & $-0.0912 * * *$ & $-0.149 * * *$ & $-0.0970 * * *$ & $-0.175 * * *$ \\
\hline & {$[0.034]$} & {$[0.052]$} & {$[0.035]$} & {$[0.053]$} \\
\hline 1993-2003 Male mean & 0.45 & 0.58 & 0.42 & 0.56 \\
\hline 1993-2003 Female mean & 0.35 & 0.41 & 0.32 & 0.36 \\
\hline$N$ & 98060 & 48694 & 86206 & 41031 \\
\hline \multicolumn{5}{|l|}{ Controlling for lagged $Y$} \\
\hline \multirow[t]{2}{*}{ Female*(2004-2014) } & 0.0044 & 0.0256 & -0.00542 & 0.0208 \\
\hline & {$[0.013]$} & {$[0.019]$} & {$[0.013]$} & [0.019] \\
\hline \multirow[t]{2}{*}{ Female baseline (1993-2004) } & $-0.0259 * *$ & $-0.0453 * *$ & $-0.0257 * *$ & $-0.0528 * * *$ \\
\hline & {$[0.012]$} & {$[0.018]$} & {$[0.012]$} & {$[0.017]$} \\
\hline$N$ & 97993 & 48662 & 86144 & 41000 \\
\hline
\end{tabular}

Note: Pscore $>99.5$ corresponds to the sample of individuals who are predicted to have a propensity to be board members above the 99.5th percentile based on their characteristics and estimates of how these characteristics affect board membership (see text for details). The second sample selects individuals with earnings above the 98th percentile for three years in a row that also have a business degree. The regressions control for year dummies are age, age squared, potential experience dummies and fixed individual characteristics (an indicator for whether the individual was working at the time of selection into his or her cohort as well as marital status and presence of children at the time the individual was selected into his or her cohort). Standard errors are clustered at the person level. ${ }^{* * *} \mathrm{p}<0.01 .{ }^{* *} \mathrm{p}<0.05 .{ }^{*} \mathrm{p}<0.1$. 